\title{
AVALIAÇÃO QUÍMICA DA DISPONIBILIDADE DOS MICRONUTRIENTES CONTIDOS NOS FERTILIZANTES
}

\author{
FABIO VALE
}

Engenheiro Agrônomo

Orientador : Prof. Dr. JOSÉ CARLOS ALCARDE

Dissertação apresentada à Escola Superior de Agricultura "Luiz de Queiróz", Universidade de São Paulo, para obtenção do título de Mestre em Agronomia, Área de Concentração: Solos e Nutrição de Plantas.

PIRACICABA

Estado de São Paulo - Brasil

Novembro - 1997 
Dados Internacionais de Catalogação na Publicação (CIP) DIVISÃo DE BIBLIOTECA E DOCUMENTAÇÃO - Campus "LUiz de Queiroz"/USP

Vale, Fabio

Avaliação quimica da disponibilidade dos micronutrientes contidos nos fertilizantes / Fabio Vale. - - Piracicaba, 1997. 67 p. : il.

Dissertação (mestrado) - Escola Superior de Agricultura Luiz de Queiroz, 1997. Bibliografia.

1. Análise quimica 2. Extrator químico 3. Fertilizante 4. Micronutriente I. Título

CDD 631.8 


\section{AVALIAÇÃO QUÍMICA DA DISPONIBILIDADE DOS MICRONUTRIENTES CONTIDOS NOS FERTILIZANTES}

FABIO VALE

Aprovada em: 12.12 .1997

Comissão julgadora:

Prof. Dr. José Carlos Alcarde

ESALQ/USP

Prof. Dr. Luis Ignácio Prochnow

ESALQ/USP

Prof. Dr. Leonardo Theodoro Büll

FCA/UNESP

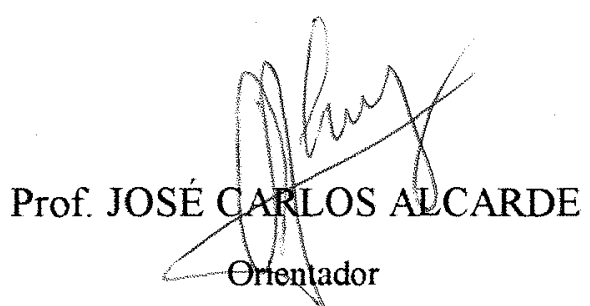


A meus pais Dario e Ana Maria

Pelo que sou.

DEDICO

\author{
À minha esposa Nélvia, \\ pelo carinho e compreensão. \\ À minha filha Júlia, e à futura. \\ Com todo o meu amor! \\ OFEREÇO
}




\section{AGRADECIMENTOS}

À Escola Superior de Agricultura Luiz de Queirơz - ESALQ/USP.

À Fundação de Amparo à Pesquisa do Estado de São Paulo - FAPESP, pela bolsa de mestrado oferecida e pelo auxílio financeiro ao projeto.

Ao Prof. Dr. José Carlos Alcarde, pela excelente orientação, estímulo e amizade.

Ao Conselho do Curso de Pós-Graduação em Solos e Nutrição de Plantas, Professores Francisco Antonio Monteiro, Quirino A. de Camargo Carmello e Álvaro Pires da Silva, pela oportunidade de ingresso no curso.

Ao Prof. Dr. Arnaldo A. Rodella, pelas sugestões apresentadas para a realização do trabalho.

Aos funcionários do Departamento de Química da ESALQ, em especial à Rita e ao Christian, pelo auxilio na condução do trabalho.

Ao Prof. Dr. Arquimedes Lavorenti, pelo auxilio na confecção do Summary.

Ao Engenheiro Agrônomo Fernando J.P.C. Carvalho, do Ministério da Agricultura, pelo auxílio na coleta das amostras de fertilizantes.

Aos companheiros de curso, em especial ao Marcelo E. Alves e Fernando C. Oliveira, pela amizade e sugestões. 


\section{SUMÁRIO}

Página

RESUMO.

vii

SUMMARY.

ix

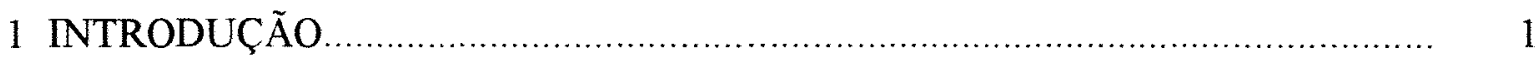

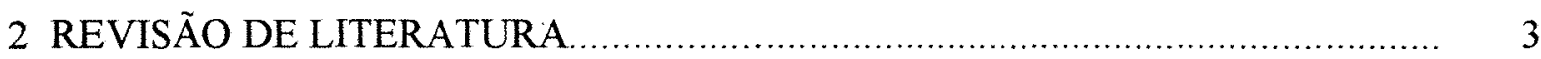

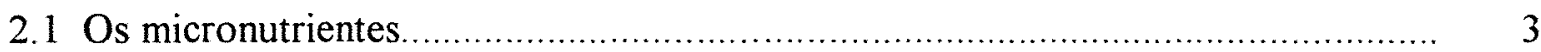

2.2 Fertilizantes com micronutrientes.................................................... 4

2.3 Extratores de micronutrientes dos fertilizantes........................................ 7

2.4 Resíduos industriais como fonte de micronutrientes ................................ 10

2.5 Método de Neubauer \& Schneider para avaliar a disponibilidade de nutrientes

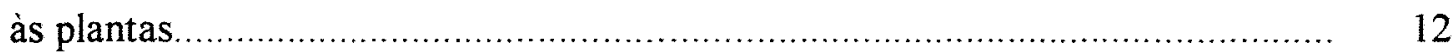

3 MATERIAL E MÉTODOS ................................................................ 14

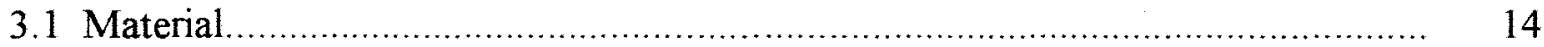

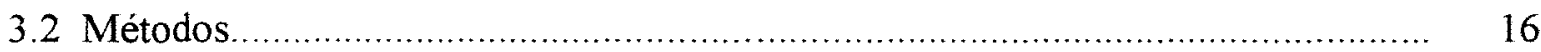

3.2.1 Avaliação química da disponibilidade dos micronutrientes nos fertilizantes.... 16

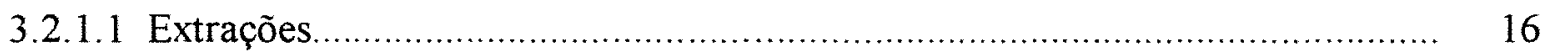

3.2.1.1.1 Teor total de micronutrientes ..................................................... 16

3.2.1.1.2 Teor de micronutrientes solúvel em água - (Brasil, 1983) ..................... 17

3.2.1.1.3 Teor de micronutrientes solúvel em solução de ácido cítrico a $2 \% \ldots \ldots \ldots \ldots . \quad 17$

3.2.1.1.4 Teor de micronutrientes solúvel em solução neutra de citrato de amônio

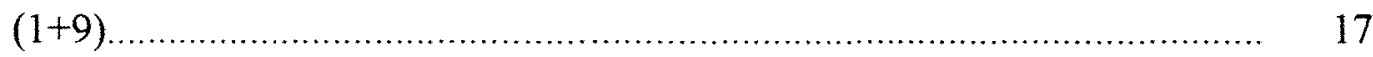

3.2.1.1.5 Teor de micronutrientes solúvel em solução de DTPA $0,005 \mathrm{~mol} \mathrm{~L}^{-1} \ldots \ldots \ldots \quad 18$

3.2.1.1.6 Teor de micronutrientes solúvel em solução de EDTA $0,005 \mathrm{~mol} \mathrm{~L}^{-1} \ldots \ldots \ldots$.

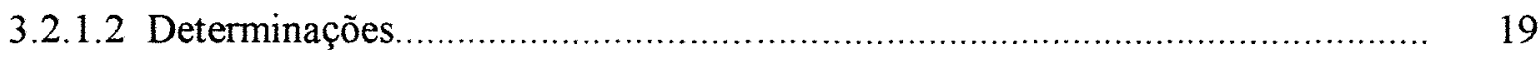

3.2.2 Avaliação do aproveitamento dos micronutrientes pelas plantas.................... 20

3.2.3 Tratamento estatístico....................................................................... 20

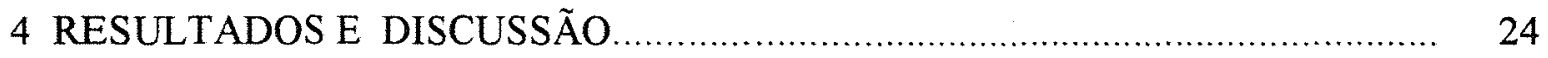

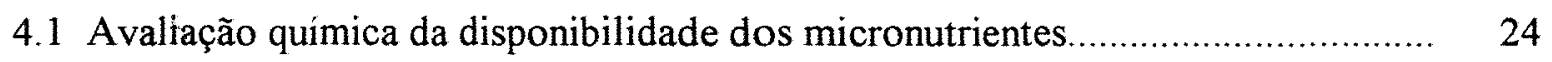


4.1.1 Micronutrientes catiònicos .................................................................. 24

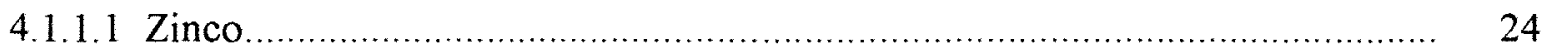

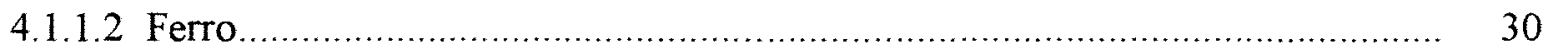

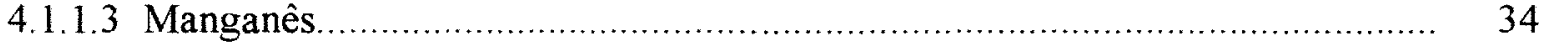

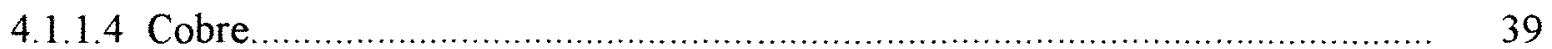

4.1.2 Micronutrientes aniônicos ................................................................ 44

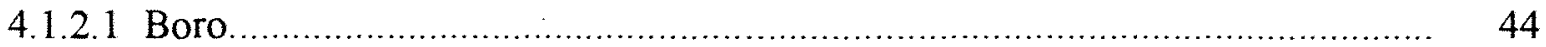

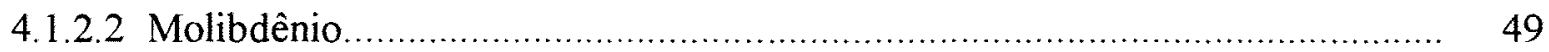

4.2 Disponibilidade dos micronutrientes para as plantas pelo método de Neubauer \&

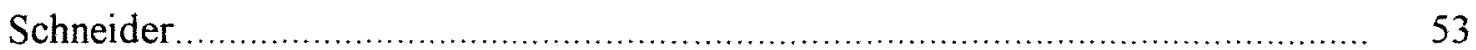

5 CONCLUSÕES

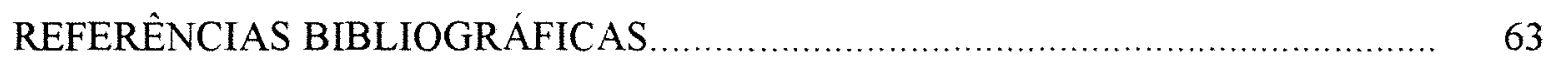




\title{
AVALIAÇÃO QUÍMICA DA DISPONIBILIDAdE DOS MICRONUTRIENTES CONTIDOS NOS FERTILIZANTES
}

\author{
Autor: Fabio Vale \\ Orientador: Prof. Dr. José Carlos Alcarde
}

\section{RESUMO}

A legislação brasileira exige que os micronutrientes nos fertilizantes sejam garantidos pelo teor total presente. Isto abre um precedente para a utilização de produtos não considerados como fontes de micronutrientes na fabricação dos fertilizantes. Um exemplo disso é a comercialização de zinco metálico com rótulo de óxido de zinco. Porém a eficiência agronômica desses produtos é ainda duvidosa.

Objetivou-se, então, realizar um trabalho para tentar caracterizar a disponibilidade dos micronutrientes em trinta fertilizantes comerciais, através do uso de cinco extratores químicos: a água, e as soluções de ácido cítrico a $2 \%$, de citrato neutro de amônio $(1+9)$, de DTPA $0,005 \mathrm{~mol} \mathrm{~L}^{-1}$ e de EDTA 0,005 $\mathrm{mol} \mathrm{L}^{-1}$. Também foram feitas correlações entre os teores solúveis dos micronutrientes nos fertilizantes e sua absorção pelas plantas de arroz, através de testes do tipo Neubauer \& Schneider, procurando identificar o extrator que melhor caracterizou a disponibilidade dos micronutrientes para as plantas, nos fertilizantes.

Os resultados mostraram a baixa solubilidade dos micronutrientes metálicos (cobre, ferro, manganês e zinco) dos fertilizantes tipo "fritas". O ácido cítrico a $2 \%$ se mostrou promissor na caracterização da disponibilidade de cobre, manganês e zinco para as plantas. Para o ferro não houve uma definição entre os extratores estudados. O boro teve boa solubilidade, tanto nos fertilizantes solúveis, como nos insolúveis em água, e a garantia pelo teor total mostrou-se um bom indicativo da disponibilidade do elemento. Para o molibdênio, produtos mais solúveis foram adicionados para os fertilizantes com baixo teor do elemento, enquanto que os com teor mais elevado tenderam a uma menor 
solubilidade. A garantia dos micronutrientes catiônicos pelo teor total, conforme exige a legislação, não indicou a real disponibilidade nos fertilizantes. Mostra-se necessária a definição de extratores para esse fim, através de mais estudos. 


\title{
CHEMICAL EVALUATION OF MICRONUTRIENTS AVAILABILITY FROM FERTILIZERS
}

\author{
Author: Fabio Vale \\ Adviser: Prof. Dr. José Carlos Alcarde
}

\section{SUMMARY}

The brazilian fertilizer legislation in general requires that the presence of micronutrients be guaranteed by their total amount. This makes possible to use different products as source of micronutrients for fertilizers. As an example of this the metallic zinc is labeled as oxide zinc and sold in the market. Their agronomic efficiency is still a doubt.

The purpose of this work was to characterize the micronutrients solubility of thirty commercial fertilizers through five extractors: water, $2 \%$ citric acid, neutral ammonium citrate (1+9), 0,005 $\mathrm{mol} \mathrm{L}^{-1}$ DTPA and 0,005 $\mathrm{mol} \mathrm{L}^{-1}$ EDTA solutions. Some correlation between forms of micronutrients in the fertilizers and their absorption for rice plants, through Neubauer \& Schneider tests were also tried in order to identify the extractor that showed the best micronutrient plant availability on fertilizers.

The results showed low solubility of $\mathrm{Cu}, \mathrm{Fe}, \mathrm{Mn}$ and $\mathrm{Zn}$ on "fritted" fertilizers. The $2 \%$ citric acid has shown to be a good extractor to identify $\mathrm{Cu}, \mathrm{Mn}$ and $\mathrm{Zn}$ availability for plants. The B solubility was suitable in all fertilizers and its total amount showed to be a good indication of B availability. The Mo solubility presented high values for fertilizers with low amount of total Mo, but lower for fertilizers with high amount of total Mo. The guarantee of total amount of micronutrients in fertilizers does not show their availability: it is necessary to establish an extractor in order to quantify the micronutrient availability 


\section{INTRODUÇÃO}

A associação entre o aumento populacional desenfreado, estimado em $57 \%$ até o ano 2025 , com a necessidade em se aumentar a produção de alimentos na mesma escala, é um dos maiores desafios por que vai passar a humanidade. Estudos mundiais indicam o Brasil como um dos poucos locais possiveis de se buscar esse aumento, pois ainda possui muitas áreas aptas à agricultura e, também, por realizar uma agricultura com produtividades médias consideradas baixas. A FAO propõe ao Brasil a necessidade de se dobrar a produção de grãos já no ano 2000, atingindo 140 milhões de toneladas.

Tecnicamente existem três caminhos mais lógicos para se aumentar a produção: aumento da área cultivável, aumento da produtividade e aumento do número de cultivos. $\mathrm{O}$ aumento de áreas novas precisa ser feito com critérios corretos, para se produzir nessas áreas também com altas produtividades. É muito importante neste aspecto, um manejo correto do solo e água, incluindo-se aí a utilização da correção do solo e da adubação.

No Brasil, a utilização de fertilizantes por área é das mais baixas, perdendo para países como Costa Rica e México. Há a necessidade de se dobrar a quantidade de fertilizantes a ser colocado no solo, para podermos pensar em aumentar a produção agrícola, condizente com que a população vai precisar. Existe uma necessidade constante de programas de educação do governo e dos fabricantes, para que o fertilizante seja utilizado de maneira correta e racional.

Um grande problema muitas vezes existente, e que foge do alcance do agricultor, é o referente à qualidade do produto. Não adianta se aumentar o uso de fertilizantes por área, se o produto não for compativel com o que a planta precisa, isto é, os nutrientes não estiverem na forma em que possam ser absorvidos quando a cultura necessitar. 
A legislação brasileira de fertilizantes, ao exigir a garantia dos micronutrientes pelo teor total, abre oportunidade de se comercializar sub-produtos industriais que contenham micronutrientes, com teores totais mínimos exigidos pela legislação. Mas fica a dúvida de como é a disponibilidade desses micronutrientes nesses produtos, e como será o aproveitamento desses micronutrientes pelas plantas. Até que ponto o teor total dos elementos nos fertilizantes é importante. E uma pergunta pode ser feita: produtos feitos com materiais que não são oficialmente considerados como fertilizantes simples pela legislação brasileira, como exemplo zinco metálico, podem ser chamados de fertilizantes?

É claro que a necessidade de adubação com micronutrientes é muito grande, e que o uso de resíduos industriais poderia ser uma medida tomada visando a diminuição do preço dos fertilizantes e, consequentemente, reduzindo os custos de produção, ajudando a melhorar a qualidade e a competitividade de nossos produtos agrícolas no mercado interno e externo. Porém, há também a necessidade de prévios tratamentos desses resíduos, para que os micronutrientes neles presentes tornem-se disponiveis.

O objetivo do presente trabalho foi o de caracterizar a disponibilidade dos micronutrientes em fertilizantes comerciais, através do uso de extratores químicos diferentes. Também foram feitas correlações entre os teores solúveis dos micronutrientes nos fertilizantes e sua absorção pelas plantas de arroz, através de testes do tipo Neubauer $\&$ Schneider, procurando identificar o extrator que melhor caracterizou a disponibilidade dos micronutrientes para as plantas, nos fertilizantes. É um trabalho inicial que certamente gerará estudos mais detalhados sobre o assunto. 


\section{REVISÃO DE LITERATURA}

\subsection{Os micronutrientes}

Atualmente, sete elementos químicos absorvidos pelas plantas em pequena quantidade satisfazem os três critérios de essencialidade propostos por Arnon \& Stout (1939), sendo, portanto, considerados essenciais para o seu desenvolvimento: boro (B), cloro $(\mathrm{Cl})$, cobre $(\mathrm{Cu})$, ferro $(\mathrm{Fe})$, manganês $(\mathrm{Mn})$, molibdênio $(\mathrm{Mo})$ e zinco $(\mathrm{Zn})$. Existem alguns autores que consideram o cobalto $(\mathrm{Co})$ e o níquel $(\mathrm{Ni})$ como essenciais. A medida em que vão se desenvolvendo novas técnicas analíticas, è provável que esta lista seja aumentada, com a inclusão de novos elementos.

De acordo com Raij (1991b), os sete micronutrientes têm comportamento químico muito diferenciado. Dois são não-metais (boro e cloro) e os demais são metais pesados. $\mathrm{O}$ boro forma sempre ligações covalentes e em soluções naturais ocorre como ácido bórico. O cloro é sempre monovalente. O cobre ocorre como sulfetos, que se intemperizam, liberando o ion $\mathrm{Cu}^{2+}$ e seus complexos. $\mathrm{O}$ ferro ocorre em óxidos, silicatos e sulfetos e as valências são $2+$ e $3+$. O manganês ocorre em silicatos e óxidos, em valências $2+, 3+\mathrm{e} 4+$, sendo o $\mathrm{Mn}^{2+}$ mais importante em soluções ácidas. $\mathrm{O}$ molibdênio é, dos micronutrientes, o único metal de caráter aniònico em solos $\mathrm{e}$ minerais, ocorrendo também como sulfetos. O zinco ocorre como sulfetos e silicatos e, no intemperísmo de minerais, transforma-se em $\mathrm{Zn}^{2+}$.

Os efeitos da deficiência de micronutrientes, como limitante à produtividade, variam com a cultura e o solo, podendo ir de pequena redução na produtividade, até o total insucesso. Malavolta (1994) demonstrou que todas as culturas de maior 
importância econômica são afetadas pela carència de um ou mais micronutrientes, e que as deficiências se mostram praticamente em todo o território nacional. Deficiências de boro afetam com maior intensidade a cultura do café, seguida pelo citrus e olerícolas, entre outras. Exemplos de culturas mais exigentes em cobre são as do trigo, café, canade-açúcar e citrus. A cultura do abacaxi é uma das poucas que apresentam deficiências de ferro, enquanto que os citrus são plantas que podem apresentar facilmente deficiência de manganès. Sintomas de falta de zinco podem aparecer nas culturas do arroz e milho, citrus e café, entre outras. Isso reforça o porque da necessidade de utilização dos micronutrientes nas adubações, e de maneira correta e racional. As funções dos micronutrientes para as plantas, assim como seus sintomas de deficiências podem ser encontrados em Malavolta (1980).

No Brasil, segundo Lopes (1984), alguns aspectos justificam a preocupação com micronutrientes: cultivos intensivos com alta tecnologia em solos que anteriormente possuiam alta fertilidade natural e hoje estão empobrecidos; incorporação de solos com baixa fertilidade ao processo produtivo, como os de cerrado; aumento na produção e uso de fertilizantes de alta concentração, com menores quantidades de micronutrientes como impurezas; maior utilização de calcários nos solos, que contribui para a insolubilizacão de vários micronutrientes.

O quadro aponta, então, para um agravamento geral das deficiências de nutrientes, tornando-se, hoje em dia, uma obrigatoriedade as análises de plantas e solos, para posteriores reposições dos elementos que estarão em falta para o processo produtivo.

\subsection{Fertilizantes com micronutrientes}

As fontes de micronutrientes e suas respectivas garantias mínimas exigidas pelo Ministério da Agricultura (Brasil, 1982) são apresentadas na Tabela 1. 
Tabela 1 - Garantias mínimas de teores de micronutrientes em adubos exigidas pelo Ministério da Agricultura (Brasil, 1982)

\begin{tabular}{|c|c|c|}
\hline FERTILIZANTES SIMPLES & ESPECIFICAÇÕES & CARACTERISTICAS \\
\hline \multicolumn{3}{|l|}{ Silicatos findidos de: } \\
\hline Cobre & $10 \%$ de Cu total & Produtos obtidos pela fusão da silica com \\
\hline Manganès & $15 \%$ de Mn total & fontes diversas de micronutrientes \\
\hline Ferro & $20 \%$ de Fe total & \\
\hline Zinco & $10 \%$ de $\mathrm{Zn}$ total & \\
\hline Molibdènio & $20 \%$ de Mo total & \\
\hline Cobalto & $10 \%$ de Co total & \\
\hline Boro & $06 \%$ de B total & \\
\hline Bórax & I $1 \%$ de $B$ solúvel em água & Boro na forma de borato de sódio \\
\hline Acido bórico & $17 \%$ de $B$ soluvel em àgua & Boro na forma de ácido bórico \\
\hline Pentaborato de sódio & $18 \%$ de B total & Boro na forma de borato de sódio \\
\hline Ulexita & $8 \%$ de B total & Boro na forma de borato de sódio e cálcio \\
\hline Colemanita & $8 \%$ de $B$ total & Boro na forma de borato de calcio \\
\hline Boro-etanolamina & $8 \%$ de B solúvel em igua & Boro na forma de éster \\
\hline Boro orgànico & $8 \%$ de B total & Boro na forma de éster ou amida \\
\hline Cloreto de sódio & $57 \%$ de $\mathrm{Cl}$ solúvel em água & Cloro na forma de $\mathrm{NaCl}$ \\
\hline Cloreto de niquel & $25 \%$ de Cl solúvel em água & Cloro na forma de $\mathrm{NiCl} 2 . \mathrm{H}_{2} \mathrm{O}$ \\
\hline Sulfato de cobre & $20 \%$ de Cu soluvel em agua & Cobre na forma de $\mathrm{CuSO}_{4}$ \\
\hline Fosfato cuprico amoniacal & $30 \%$ de Cu total & $\begin{array}{l}\text { Cobre na forma de fosfato duplo de amònio } \\
\text { e Cobre }\end{array}$ \\
\hline Carbonato de cobre & $54 \%$ de Cu total & Cobre na forma de $\mathrm{CuCO} 3{ }_{3} \mathrm{Cu}(\mathrm{OH})_{2}$ \\
\hline Cloreto de cobre & $37 \%$ de $\mathrm{Cu}$ solúvel em agua & Cobre na forma de $\mathrm{CuCl}_{2} \mathrm{nH}_{2} \mathrm{O}$ \\
\hline Óxido de cobre & $75 \%$ de Cu total & Cobre na forma de $\mathrm{CuO}$ ou $\mathrm{Cu}_{2} \mathrm{O}$ \\
\hline Nitrato de cobre & $22 \%$ de $\mathrm{Cu}$ solivel em água & Cobre na forma de $\mathrm{Cu}\left(\mathrm{NO}_{3}\right)_{2} 3 \mathrm{H}_{2} \mathrm{O}$ \\
\hline \multicolumn{3}{|l|}{ Quelatos de: } \\
\hline Cobalto & $2 \%$ de Co solúvel em água & $\mathrm{Co}, \mathrm{Cu}, \mathrm{Fe}, \mathrm{Mn}, \mathrm{Zn}$. ligados ao EDTA. \\
\hline Cobre & $5 \%$ de $\mathrm{Cu}$ solúvel em água & DTPA, EDDHA HEEDTA EDDHMA. \\
\hline Ferro & $5 \%$ de Fe solúvel em água & EDDCHA;poliflavonöides, lignosulfonados.. \\
\hline Manganès & $5 \%$ de $\mathrm{Mn}$ solúvel em agua & Cada produto deverá conter somente um \\
\hline Zinco & $5 \%$ de Zn solúvel em água & nutriente, totalmente quelatizado. \\
\hline Fosfato ferroso amoniacal & $28 \%$ de Fe solúvel em água & Ferro na forma de $\mathrm{Fe}\left(\mathrm{NH}_{4}\right) \mathrm{PO}_{4}$ \\
\hline Polifosfato de ferro e amònio & $21 \%$ de Fe total & Ferro na forma de $\mathrm{Fe}\left(\mathrm{NH}_{4}\right) \mathrm{HP}_{2} \mathrm{O}$ ? \\
\hline Sulfato de ferro & $19 \%$ de Fe solúvel em água & Ferro na forma de $\mathrm{Fe}_{2}\left(\mathrm{SO}_{4}\right)_{3}$ ou $\mathrm{FeSO}_{4}$ \\
\hline Cloreto férrico & $16 \%$ de Fe solúvel em agua & Ferro na forma de $\mathrm{FeCl}_{3} 6 \mathrm{H}_{2} \mathrm{O}$ \\
\hline Clorato ferroso & $23 \%$ de $\mathrm{Fe}$ solúvel em água & Ferro na forma de $\mathrm{FeCl} z .4 \mathrm{H}_{2} \mathrm{O}$ \\
\hline Nitrato férrico & $11 \%$ de Fe soluvel em agua & Ferro na forma de $\mathrm{Fe}\left(\mathrm{NO}_{3}\right)_{3} .9 \mathrm{H}_{2} \mathrm{O}$ \\
\hline Carbonato de ferro & $41 \%$ de Fe total & Ferro na forma de $\mathrm{FeCO}_{3}$ \\
\hline Sulfato manganoso & $28 \%$ de $\mathrm{M} n$ solúvel emagua & Manganès na forma de $\mathrm{MnSO}_{4}$ \\
\hline Cloreto de manganes & $35 \%$ de $\mathrm{Mn}$ solúvel em agua & Manganès na forma de $\mathrm{MnCl}_{2} \mathrm{nH}_{2} \mathrm{O}$ \\
\hline Óxido manganoso & $41 \%$ de $\mathrm{Mn}$ total & Manganès na forma de $\mathrm{MnO}$ \\
\hline Carbonato de manganès & $45 \%$ de Mn total & Manganès na forma de $\mathrm{MnCO}_{3}$ \\
\hline Nitrato de manganès & $16 \%$ de Mn solúvel em agua & Manganès na forma de $\mathrm{Mn}\left(\mathrm{NO}_{3}\right)_{2} .6 \mathrm{H}_{2} \mathrm{O}$ \\
\hline Molibdato de amónio & $45 \%$ de Mo soluvel em a gua & Molibdènio na forma de $\left(\mathrm{NH}_{4}\right)_{2} \mathrm{MoO}_{4}$ \\
\hline Trióxido de molibdènio & $58 \%$ de Mo total & Molibdènio na forma de óxido \\
\hline Molibdato de sódio & $35 \%$ de Mo solível em água & Molibdènio na forma de $\mathrm{Na}_{2} \mathrm{MoO}_{4}$ \\
\hline Cloreto de zinco & $30 \%$ de $\mathrm{Zn}$ solúvel em agua & Zinco na forma de $\mathrm{ZnCl}_{2} . \mathrm{nH}_{2} \mathrm{O}$ \\
\hline Carbonato de zinco & $50 \%$ de $\mathrm{Zn}$ total & $\begin{array}{l}\text { Zinco na forma de } \mathrm{ZnCO}_{3} \text {, isento de } \mathrm{Zn} \\
\text { metálico }\end{array}$ \\
\hline Nitrato de zinco & $22 \%$ de $\mathrm{Zn}$ solúvel em agua & Zinco na forma de $\mathrm{Zn}\left(\mathrm{NO}_{3}\right){ }_{2} 6 \mathrm{H}_{2} \mathrm{O}$ \\
\hline Óxido de zinco & $50 \%$ de Zn total & $\begin{array}{l}\text { Zinco na forma de } \mathrm{ZnO} \text {. isento de } \mathrm{Zn} \\
\text { metalico }\end{array}$ \\
\hline Oxi-sulfato de zinco & $20 \%$ de $\mathrm{Zn}$ total $(1 / 3$ soluvel $\mathrm{em}$ & \\
\hline Sulfato de zinco & água) & Zinco na forma de $\mathrm{ZnSO}_{4}$ \\
\hline Cloreto de cobalto & $20 \%$ de $\mathrm{Zn}$ solúvel em água & Cobatto na forma de $\mathrm{CoCl}_{2} \cdot \mathrm{nH}_{2} \mathrm{O}$ \\
\hline Óxido de cobalto & $24 \%$ de Co solúvel em água & Cobalto na forma de oxido \\
\hline Sulfato de cobalto & $56 \%$ de Co total & Cobalto na forma de $\mathrm{CoSO}_{4} .7 \mathrm{H}_{2} \mathrm{O}$ \\
\hline Nitrato de cobatto & $16 \%$ de Co solúvel em água & Cobatto na forma de $\mathrm{Co}\left(\mathrm{NO}_{3}\right)_{2} .6 \mathrm{H}_{2} \mathrm{O}$ \\
\hline Fosfato de cobalto & $17 \%$ de $\mathrm{Co}$ solúvel em água & Cobahto na forma de $\mathrm{CO}_{3}\left(\mathrm{PO}_{4}\right)_{2}$ \\
\hline Carbonato de cobalto & $41 \%$ de Co total & Cobaho na forma de $\mathrm{CoCO}_{3}$ \\
\hline
\end{tabular}


Destas fontes, algumas são solúveis em água, como os quelatos, enquanto outras são insolúveis, mas disponiveis pelas plantas quando aplicadas no solo: é o caso dos carbonatos, fosfatos, oxidos, "fritas", dentre outras

O termo "fritas", de acordo com Malavolta (1981) é uma tradução literal do inglès "frited trace elements" (F.T.E.). Os micronutrientes, juntamente com sílica, são fundidos à $1300{ }^{\circ} \mathrm{C}$; ao sair do forno o produto é resfriado rapidamente em água, gerando cristais borossilicatados, que em seguida são moídos muito finamente.

O modo de aplicação do adubo contendo micronutrientes, visando-se ter uma eficiência agronômica desejável é também de grande importância. Volkweiss (1991) citou que pode-se ter aplicação via solo, via foliar, e nas sementes. Com a aplicação via solo busca-se aumentar a concentração na solução do solo, que é de onde as raizes os absorvem. É necessário, portanto, utilizar fontes de micronutrientes que se solubilizem em velocidade compativel com a absorção pelas raizes e que sejam aplicadas em posição possível de serem por elas atingidas. Na confecção de produtos para aplicação via solo, normalmente são usadas fontes solúveis e insolúveis. Porém as fontes insolúveis em água devem ser bem misturadas ao solo, para que sua eficiència seja exercida. As fontes solúveis são mais eficientes se localizadas, diminuindo a interação com o solo.

Para a aplicação via solo, o que vem se seguindo na prática, atualmente, é a utilização de adubos NPK granulados contendo micronutrientes no grânulo. A pequena concentração dos micronutrientes nestes adubos, aliado a quantidade com que são utilizados, facilita a aplicação uniforme na lavoura. Em vista disto, a tendência atual é a substituição de outras fontes por adubos NPK com micronutrientes para a adubação no solo.

No que diz respeito à aplicação foliar, ainda segundo Volkweiss (1991), é uma prática que vem crescendo muito no Brasil, principalmente com uso de zinco e boro em culturas perenes. Tem as vantagens de se ter uma aplicação mais uniforme, mais localizada, de mais rápida utilização pelas plantas, porém com custos de aplicação maiores que no solo. As fontes de micronutrientes devem ser solúveis em água, sendo os sulfatos mais indicados, podendo-se usar também os quelatos. 
A aplicação de micronutrientes em sementes é o método mais usado para a aplicação de molibdênio e cobalto em plantas. Além deles, o boro, cobre, manganês e zinco já foram aplicados em sementes, muitas vezes com resultados positivos, citados por Santos et al. (1982) e Mortvedt (1985). Fontes solúveis em água são preferiveis, porém Giordano (1977) citou casos em que fontes insolúveis são eficientes.

\subsection{Extratores de micronutrientes dos fertilizantes}

A legislação brasileira tenta dar alguma caracteristica para cada produto e especifica a garantia mínima do micronutriente em cada um (Tabela 1), (Brasil,1982). Porém Alcarde \& Rodella (1993), dizem que esta legislação abre um precedente que pode estar sendo usado por produtores de fertilizantes inescrupulosos: a garantia e os métodos oficiais de análise (Brasil,1983) contemplam o teor total dos micronutrientes. Isto dá oportunidade de se comercializar diversos sub-produtos industriais que contenham micronutrientes, com teores totais mínimos exigidos pela legislação nos diferentes fertilizantes simples contendo micronutrientes, mas com esses micronutrientes estando nas formas quimicas com que se rotulam e previstas na legislação. Um exemplo dessa fraude, com grande possibilidade de acontecer, é a comercialização de zinco metálico sob o rótulo de óxido de zinco.

Essas formas químicas não contempladas na legislação como fonte de micronutrientes, como o zinco metálico, silicato de zinco e sulfeto de zinco, são de eficiência agrícola ainda duvidosa e, além disso, podem ter teores elevados de contaminantes que, com o passar do tempo, podem ser grandes poluentes dos solos, podendo afetar a colheita e a qualidade dos produtos. Por exemplo, na formulação 04$14-08+0,5 \%$ de $\mathrm{Zn}$ a legislação não exige qualquer caracterização da forma com que o zinco se encontra: considera-se o teor total e analisa-se como tal.

O primeiro nutriente presente em fertilizantes que teve sua disponibilidade baseada no teor total contestada foi o fósforo. Atualmente, segundo Raij (1991a), a caracterização dos fertilizantes fosfatados no Brasil tem sido feita através de quatro 
determinações: (i) a do teor total de $\mathrm{P}_{2} \mathrm{O}_{5}$, que inclui todas as formas químicas; (ii) a do teor solúvel em citrato neutro de amônio + água $\left(\mathrm{CNA}+\mathrm{H}_{2} \mathrm{O}\right)$, utilizado para avaliar o fósforo disponivel dos fertilizantes fosfatados acidulados; (iii) a do teor solúvel em ácido cítrico a $2 \%$, empregado para avaliar o fósforo disponivel em fosfatos naturais ou termofosfatos; (iv) e a do teor solúvel em água. A legislação brasileira exige que os teores de fósforo solúveis em cada extrator sejam mencionados na embalagem (Brasil, 1983) e que os extratores sejam empregados de acordo com o fertilizante fosfatado analisado (Alcarde, 1992). Prochnow (1996) citou que a avaliação da disponibilidade imediata de fósforo dos fertilizantes fosfatados acidulados, através do extrator CNA + $\mathrm{H}_{2} \mathrm{O}$ mostrou-se inadequada, quando se utiliza rochas fosfatadas com alto teor de impurezas de ferro e alumínio usadas na fabricação dos fertilizantes. Como se observa, é um assunto em que os estudos não estão esgotados.

A água é considerado o extrator universal. Sua extração é uma excelente indicação da presença de elementos altamente solúveis, prontamente disponíveis, seja em solos ou fertilizantes.

Alcarde \& Ponchio (1979) esclareceram a ação solubilizante dos extratores usados na determinação do fósforo solúvel dos fertilizantes. A solução neutra de citrato de amônio (CNA) é uma solução tampão relativamente concentrada, de pH 7,0, surgida em 1871, enquanto que a solução de ácido cítrico (AC) é mais diluída, mas com acidez elevada, isto é, pH 2,30, surgida em 1899. Demostraram, com base nas constantes de estabilidade do ânion citrato, a habilidade que o $\mathrm{CNA}$, no $\mathrm{pH}$ neutro, e o $\mathrm{AC}$, em condições de acidez, têm em formar complexos com cátions presentes, e passíveis de serem disponiveis, entre eles o $\mathrm{Ca}, \mathrm{Cu}, \mathrm{Fe}, \mathrm{Mg}, \mathrm{Mn}, \mathrm{Na}$ e $\mathrm{Zn}$. Fica claro a capacidade dos dois extratores em solubilizar os micronutrientes metálicos. Em contrapartida, são liberados para a solução, também, os ânions acompanhantes, como os fosfatos, sulfatos, molibdatos e boratos. Os autores citam também, que as características físico-químicas dos fertilizantes é de grande importância, como estrutura cristalina, grau de pureza e porosidade, na solubilização.

Agentes quelantes se mostraram promissores para avaliar a disponibilidade de micronutrientes catiônicos no solo. Esses agentes combinam com os metais livres em 
solução, formando complexos solúveis, e reduzem a atividade do metal livre na solução. Em resposta, metais são dessorvidos, se desligando da fase sólida para reabastecer os metais livres na solução, até atingir o equilibrio. A quantidade de metais que se acumula na solução durante a extração é função tanto da atividade do ín metálico, como da habilidade do solo em repor esses ions. Lindsay \& Norvell (1978) utilizaram o ácido dietilenopentacético (DTPA) como extrator de $\mathrm{Cu}, \mathrm{Fe}, \mathrm{Mn}$ e $\mathrm{Zn}$ dos solos. Escolheram a solução de DTPA a $\mathrm{pH}=7,30$ por ser a que apresentava a mais favorável combinação de constantes de estabilidade para complexações simultâneas dos micronutrientes metálicos. De acordo com os autores, neste $\mathrm{pH}$ há a maior habilidade do DTPA complexar $\mathrm{Cu}, \mathrm{Fe}, \mathrm{Mn}$ e $\mathrm{Zn}$, em competição com o cálcio e magnésio.

Outro agente quelante bastante citado e utilizado é $o$ ácido etilenodiaminotetracético (EDTA). Ringbom (1963) relatou que os valores de $\mathrm{pH}$ em que as constantes de estabilidade do EDTA complexam $\mathrm{Cu}, \mathrm{Fe}, \mathrm{Mn}$ e $\mathrm{Zn}$ estão entre 9 e 10. Muraoka et al. (1983 a,b) estudando o EDTA e o EDTA $+\mathrm{CaCl}_{2}$ no pH original dos solos utilizados (entre 5,35 e 6,10), concluiram que o segundo extrator foi eficiente na avaliação da disponibilidade de $\mathrm{Zn}$ dos solos; o mesmo não ocorreu para o $\mathrm{Mn}$.

É de se esperar que, de forma semelhante ao que ocorre com o AC e CNA, com a adaptação do uso de agentes quelantes na análise de disponibilidade de micronutrientes em fertilizantes, quando ocorrer complexação de $\mathrm{Cu}, \mathrm{Fe}, \mathrm{Mn}$ e $\mathrm{Zn}$, e também de $\mathrm{Ca}, \mathrm{Mg}$ e $\mathrm{Na}$, se estes estiverem presentes, ocorrerá também a solubilização de ânions fosfato, borato e molibdato presentes.

Em recente pesquisa, Alcarde \& Rodella (1993) objetivaram estabelecer um procedimento analítico, viável de utilização em rotina, que permitisse reconhecer se um material contendo zinco pode ou não ser considerado fertilizante simples. Os materiais testados foram zinco metálico pulverizado, óxido de zinco em pó, quatro amostras de óxido de zinco comercial de diversas procedências, carbonato de zinco comercial, duas amostras de sulfeto de zinco, sendo uma comercial e uma como sub-produto de metalurgia, cinco amostras de silicato de zinco comercial de diferentes procedências, e três misturas de zinco metálico com óxido de zinco. O estudo baseou-se no uso das soluções extratoras: cloreto de amônio $2 \mathrm{M}, 1,5 \mathrm{M}$ e $1 \mathrm{M}$, citrato de amônio de densidade 
1,09 e pH=7,0, isto é, a mesma solução usada na avaliação do fósforo, na concentração original e nas diluições $(1+1),(1+3)$ e $(1+9)$, e solução de ácido cítrico a $2 \%$. As técnicas de extração foram agitação ou fervura da amostra com as soluções extratoras. Os resultados mostraram que a fervura da amostra com a solução de citrato de amônio na diluição $(1+9)$ foi a que melhor caracterizou os fertilizantes simples contendo zinco insolúvel em água. Outra constatação foi que os produtos não fertilizantes contendo zinco insolúvel em água existentes no mercado apresentaram teores elevados de cobre, chumbo e cádmio.

\subsection{Resíduos industriais como fonte de micronutrientes}

$\mathrm{O}$ emprego de residuos industriais como fontes mais baratas de micronutrientes é relatado por Nikitin (1960), o qual menciona a matéria-prima e os processos usuais de obtenção: rejeito de cobre metálico e óxido de zinco que são lixiviados por ácido sulfúrico, convertendo-se nos sulfatos respectivos. O manganês pode ser recuperado a partir de escórias de altos fornos. Sulfato ferroso é obtido quando o ferro ou o aço são mergulhados em ácido sulfúrico na limpeza preparatória para a galvanização. Certamente esses produtos obtidos são solúveis, pois há um tratamento do resíduo antes de utiliza-lo como fonte de micronutrientes. O problema maior é a utilização dos residuos como estão, na forma metálica, diretamente na adubação, pois os micronutrientes certamente não estarão disponiveis.

Mortvedt \& Cunningham (1971) descrevem que o óxido de zinco e o sulfato de manganês podem ser obtidos como subprodutos da fabricação de $\mathrm{Na}_{2} \mathrm{~S}_{2} \mathrm{O}_{4}$ e $\mathrm{Na}_{2} \mathrm{~S}_{2} \mathrm{O}_{3}$ respectivamente, ou produção de outros materiais. Mencionam que alguns desses subprodutos podem também conter quantidades apreciáveis de metais pesados, como o chumbo, não se sabendo se no caso de serem aplicados ao solo teriam algum efeito sobre as plantas. De acordo com Mortvedt (1985), muitos subprodutos industriais contendo micronutrientes são comercializados nos E.U.A.. A maior parte desses como fontes de $\mathrm{Mn}$ ou de $\mathrm{Zn}$. São fontes de $\mathrm{Zn}$ como subproduto: ácidos usados na indústria de 
galvanização e outros, pós recuperados de chaminés ou de armazéns de ensacamento, resíduos de fundição de zinco e de indústrias de pigmentos, baterias, borracha e outras. Para o autor, lixiviação é necessária para remover impurezas desses produtos, mas alguns deles são usados sem purificação. Alguns ácidos usados também contém ferro, que pode ser precipitado como $\mathrm{FeSO}_{4}$. Ainda segundo Mortvedt (1985), alguns dos subprodutos industriais podem conter também metais pesados como contaminantes, como cádmio, crômio, níquel e chumbo em concentrações muito variáveis, porém como geralmente as doses de micronutrientes usadas são baixas, a adição do metal pesado será ainda menor. Os resíduos ou sub-produtos contendo micronutrientes estão disponiveis em vários países, de acordo com Lopes (1991). Por exemplo, pneus contém uma alta porcentagem de óxido de zinco. Se os pneus descartados fossem queimados, as cinzas poderiam apresentar uma alta percentagem do elemento. As aparas de metal, escórias, residuos de indústria de galvanoplastia, baterias são também fontes em potencial. Vários processos são usados para remover impurezas desses materiais, mas alguns produtos contendo $\mathrm{ZnO}$ são usados sem purificação. Cita, também, que sub-produtos de cloretos, nitratos, sulfatos e oxi-sulfatos de $\mathrm{Zn}$, e sulfatos e oxi-sulfatos de Mn são também comercializados como fonte de micronutrientes. Comenta sobre o problema de contaminações com metais pesados, mas não considera nada sobre disponibilidade.

A preocupação da empresa Produquimica, produtora de fertilizantes com micronutrientes, em razão da polèmica causada com a importação de um material para ser usado como fonte de micronutrientes para fertilizantes, fez gerar um trabalho de autoria de Malavolta (1994). Nele, o autor faz uma avaliação sobre o potencial de uso desse material. O resíduo apresentava a seguinte constituição: $44,9 \%$ de $\mathrm{Zn}, 8,2 \%$ de $\mathrm{Cu}$, $0,16 \%$ de $\mathrm{Fe}, 0,69 \%$ de $\mathrm{Mn}$, além de concentrações inferiores de metais pesados tóxicos. Se o resíduo fosse usado diretamente para fornecer $\mathrm{Zn}$, teria de ser usado para fornecer uma dose de aproximadamente $5 \mathrm{~kg}$ por hectare, isto é, dever-se-ia aplicar inicialmente $11 \mathrm{~kg}$ do produto por hectare, a cada dois anos, devido ao efeito residual. Discute também que jamais ocorrerão prejuízos ao ambiente nesta dose, mas não comenta nada sobre necessidade de tratamento do resíduo para que os micronutrientes fiquem disponiveis às plantas. 
Amaral Sobrinho (1993) e Amaral Sobrinho et al. (1993) estudaram a eficiência de um residuo siderúrgico como corretivo e fonte de $\mathrm{Cu}, \mathrm{Fe}, \mathrm{Mn}, \mathrm{Ni}$ e $\mathrm{Zn}$. Na análise do solo, os teores de $\mathrm{Fe}, \mathrm{Mn}$, Ni e $\mathrm{Zn}$ aumentaram, e o de $\mathrm{Cu}$ sofreu decréscimo. Houve correlação, positiva e significativa, somente entre os teores de $\mathrm{Cu}$ e $\mathrm{Ni}$ do solo e as quantidades absorvidas pelo sorgo, o que parece indicar que os demais elementos não estavam em forma disponivel para as plantas.

Amaral (1994), avaliando um resíduo da indústria de zinco, com 2,5 a $3 \%$ de zinco total, como corretivo da acidez e fonte de zinco e metais pesados para plantas de milho e eucalipto, concluiu que, em doses altas o resíduo tem potencial para ser considerado uma fonte de zinco, principalmente para o milho. O grande problema encontrado foi que a aplicação de doses elevadas permitiu a detecção de cádmio no solo e nas plantas de milho, em concentrações acima do limite máximo admitido para a alimentação humana e animal. Para o eucalipto não encontrou-se esse problema, porém o problema ocorrido com o milho praticamente inviabilizou o uso geral do produto como fonte de zinco.

\subsection{Método de Neubauer \& Schneider para avaliar a disponibilidade de nutrientes às plantas}

O método de Neubauer \& Schneider, citado por Catani \& Bergamin Filho (1961), para a avaliação da quantidade de nutrientes disponiveis no solo baseia-se no conceito de que um grande número de plantas cultivadas num pequeno volume de terra haverão de, em pouco tempo, exaurir os elementos disponiveis da amostra de solo. A análise das plantas possibilitará a avaliação do que estava disponivel no solo. O método inicialmente foi proposto para se medir os teores de fósforo e potássio do solo. Consistia no cultivo de 100 plantinhas de centeio em $100 \mathrm{~g}$ de terra diluido com areia de quartzo puro. Depois de 14-18 dias de crescimento, a parte aérea e as raizes eram colhidas, incineradas e analisadas para esses dois nutrientes. 
Em face das dificuldades encontradas na aplicação do método original, ele foi sendo modificado em alguns detalhes por diversos autores. Assim, o centeio foi substituido pelo arroz (Catani \& Paiva Netto, 1950), planta mais adaptada às condições do Estado de São Paulo. As quantidades de terra e areia foram reduzidas por Catani \& Bergamin Filho (1961), com resultados análogos aos obtidos pelo método original.

Mello (1973) concluiu que o método não foi eficiente para avaliar o teor de cálcio disponivel de um solo que havia recebido doses crescentes de carbonato de cálcio, provavelmente devido ao aproveitamento por parte das plantas do cálcio do solo.

Mais recentemente, Mattiazzo-Prezotto (1994) avaliando a biodisponibilidade de $\mathrm{Cu}$ e $\mathrm{Zn}$ proveniente de resíduos industriais pelo método de Neubauer \& Schneider, encontrou boas correlações entre os teores dos elementos nas plantas e o teor extraído dos solos pelo extrator salino $\mathrm{Ca}\left(\mathrm{NO}_{3}\right)_{2} 0,05 \mathrm{~mol} \mathrm{~L}^{-1}$ e pelo DTPA $0,05 \mathrm{~mol} \mathrm{~L}^{-1}$. 


\section{MATERIAL E MÉTODOS}

\subsection{Material}

O estudo foi conduzido no Departamento de Química da Escola Superior de Agricultura "Luiz de Queiróz" - ESALQ, da Universidade de São Paulo.

Foram utilizadas 30 amostras de fertilizantes comerciais diferentes, para a caracterização da disponibilidade dos micronutrientes nos mesmos. Foram selecionados produtos considerados de solubilidade lenta, como as fritas e boratos, e produtos mais solúveis, como os sais e quelatos para aplicação foliar, em que, teoricamente, todo o micronutriente está prontamente disponivel. As garantias desses fertilizantes se encontram listados na Tabela 2.

As amostras foram coletadas segundo metodologia descrita em Brasil (1982). Foram, então, levadas ao laboratório para serem preparadas, visando homogeneização, que consistiu em quarteação da amostra em quarteador tipo "Jones" até se atingir, aproximadamente, 100 gramas de fertilizante por amostra. A seguir, as amostras foram moídas manualmente, em gral de porcelana, até que passassem por completo em peneira com abertura de malha de $0,84 \mathrm{~mm}$ (ABNT $\mathrm{n}^{\mathrm{o}} 20$ ). O objetivo desse método de moagem utilizado foi o de procurar evitar contaminação dos fertilizantes por micronutrientes derivados de outros locais, como por exemplo das hélices do moinho. Uma importante observação ocorrida nesta fase, e com ligação ao objetivo da pesquisa, foi a presença de uma certa quantidade de impurezas metálicas de diâmetro superior à $0,84 \mathrm{~mm}$ que ficavam retidas na peneira, como fios de cobre, pontas de aço, etc. Visualmente se observou muitas impurezas metálicas com diâmetro de partículas menores que o da 
peneira utilizada, que passaram para a porção de fertilizante a ser analisada, provavelmente insolúveis no solo, mas que terão seu teor de micronutrientes contemplado numa análise pelo teor total.

Tabela 2 - Fertilizantes comerciais utilizados no presente trabalho, suas respectivas garantias, e forma fisica em que se apresentavam.

\begin{tabular}{|c|c|c|c|c|c|c|c|c|c|c|}
\hline \multirow{2}{*}{$N^{\mathrm{o}}$} & \multirow{2}{*}{ Identificação } & \multirow{2}{*}{ Empresa } & \multirow{2}{*}{ Tipo } & $\mathrm{B}$ & $\mathrm{Cu}$ & $\mathrm{Fe}$ & $\mathrm{Mn}$ & Mo & $\overline{Z n}$ & \multirow{2}{*}{ Forma } \\
\hline & & & & \multicolumn{6}{|c|}{ - $\%$ - } & \\
\hline 01 & FTE BR-12 & Nutriplant & Frita & 1.8 & 0,8 & 3,0 & 2.0 & 0.1 & 9,0 & Granulado \\
\hline 02 & FTE Sementes & Nutriplant & Frita & 2.5 & - & - & 2.0 & 6.0 & 25.0 & Pó \\
\hline 03 & FTE JCO 2M & Nutriplant & Frita & 2.0 & 5,0 & 5.0 & 8.0 & - & 5,0 & Pó \\
\hline 04 & FTE Centro Oeste & Nutriplant & Frita & 2,0 & 2.0 & - & 10.0 & - & 15.0 & Granulado \\
\hline 05 & Nutricitro 224 & Nutriplant & Frita & 2.0 & - & - & 4.0 & - & 20.0 & Pó \\
\hline 06 & Borogran - 10 & Nutriplant & Frita & 10,0 & - & - & - & - & - & Granulado \\
\hline 07 & Hidrozinc Frit 20 & Nutriplant & Frita & - & - & - & - & - & 20.0 & Granulado \\
\hline 08 & FTE Cerrrado S & Nutriplant & Frita & 0,5 & 1,06 & - & 6,0 & 0.01 & 13,0 & Pó \\
\hline 09 & Zincogran 20 & Nutriplant & Frita & - & - & - & - & - & 20,0 & Granulado \\
\hline 10 & FTE BR - 18 & Nutriplant & Frita & 3.6 & 1.6 & - & - & 0.2 & 18.0 & Granulado \\
\hline 11 & FTE BR - 8 & Nutriplant & Frita & 2,5 & 1.0 & 5,0 & 10.0 & 0,1 & 7,0 & Pó \\
\hline 12 & Zincoman & Nutriplant & Frita & - & 7,0 & - & 15.0 & - & 7,0 & Granulado \\
\hline 13 & $\mathrm{Mib}-4$ & Produquímica & Frita & 4,0 & - & - & - & - & 20,0 & Granulado \\
\hline 14 & $\mathrm{Mib}-3$ & Produquímica & Frita & 1,8 & 0.8 & 3,0 & 2.0 & 0,1 & 9,0 & Granulado \\
\hline 15 & Mib- 3 & Produquimica & Frita & 1,8 & 0,8 & 3,0 & 2.0 & 0.1 & 9,0 & Pó \\
\hline 16 & Mib-16A & Produquímica & Frita & 2,5 & - & - & - & 1.3 & 25,0 & Granulado \\
\hline 17 & $\mathrm{Mib}-28$ & Produquímica & Frita & 2,0 & 2.0 & - & 10.0 & - & 15,0 & Granulado \\
\hline 18 & Agrimax-12 & Fertibrás & Frita & 1.8 & 0.8 & 3,0 & 2.0 & 0.1 & 9.0 & Granulado \\
\hline 19 & Gran-0-zinc 20 & Fertibrás & Frita & - & - & 1,0 & - & - & 20.0 & Granulado \\
\hline 20 & Gran-o-bor 10 & Fertibrás & Frita & 10.0 & - & - & - & - & - & Granulado \\
\hline 21 & Agrimax CO 150 & Fertibrás & Frita & 2,0 & 2.0 & - & 10.0 & - & 15,0 & Granulado \\
\hline 22 & HGB 12 & - & Frita & 2.0 & 2.0 & - & 10,0 & - & 15,0 & Pó \\
\hline 23 & Plantzinco F IV & Agroplanta & Frita & - & - & 1,0 & - & - & 40,0 & Farelado \\
\hline 24 & Plantzinco F II & Agroplanta & Frita & - & - & - & - & - & 20,0 & Farelado \\
\hline 25 & Ulexita & Produquímica & Borato & 12,0 & - & - & - & - & & Farelado \\
\hline 26 & Boro Importado & Argentina & Borato & 15,0 & - & - & - & - & - & Granulado \\
\hline 27 & Nitrex MS - 2 & Fertibrás & Sais & 1,5 & 1,0 & - & 8,0 & - & 10,0 & Pó \\
\hline 28 & Copas - 8 (café) & Copas & Sais & 3.0 & - & - & - & - & 8,0 & Pó \\
\hline 29 & Copas - 9 (citrus) & Copas & Sais & 2,0 & - & - & 9,0 & - & 11,0 & Pó \\
\hline 30 & Nutri Oxi-Zn "C" & Oxiquímica & Quelato & - & - & - & - & - & 21.5 & Líquido \\
\hline
\end{tabular}




\subsection{Métodos}

\subsubsection{Avaliação química da disponibilidade dos micronutrientes nos fertilizantes}

Todos os produtos foram analisados quanto ao teor total de micronutrientes, o teor de micronutrientes solúvel em água, solúvel em solução de ácido cítrico a $2 \%$, de citrato neutro de amônio na diluição $1+9$, de ácido dietilenopentacético (DTPA) 0,005 mol L $\mathrm{L}^{-1}$ e de ácido etilenodiaminotetracético (EDTA) $0,005 \mathrm{~mol} \mathrm{~L}^{-1}$. Com exceção do teor total, as outras metodologias são propostas neste trabalho. A escolha dos extratores utilizados baseou-se no fato da água ser considerado o extrator universal, o ácido cítrico e o citrato neutro de amônio por já serem utilizados na rotina para determinação de fósforo solúvel em fertilizantes, e o DTPA e EDTA por serem extratores responsáveis por quelação e colocação de micronutrientes metálicos em solução, e também por serem utilizados na análise de solos para avaliar os micronutrientes disponiveis.

\subsubsection{Extrações}

\subsection{Teor total de micronutrientes - (Brasil,1983)}

a) Transferiu-se $1,0000 \mathrm{~g}$ da amostra para copo de $150 \mathrm{~mL}$, adicionou-se $10 \mathrm{~mL}$ de $\mathrm{HCl}$ concentrado, ferveu-se para evaporar até próximo à secura em chapa aquecedora, sem deixar queimar o resíduo;

b) Dissolveu-se o resíduo com $20 \mathrm{~mL}$ de solução de $\mathrm{HCl} 2 \mathrm{~mol} \mathrm{~L}^{-1}$, fervendo ligeiramente. Após, filtrou-se em papel faixa branca, recebendo o filtrado em balão de $100 \mathrm{~mL}$. Lavou-se o copo e o filtro com porções de água destilada e completou-se o volume.

c) Foi preparada uma prova em branco. 


\subsection{Teor de micronutrientes solúvel em água}

a) Transferiu-se $2,5000 \mathrm{~g}$ da amostra para papel de filtro faixa branca adaptado em funil, e colocado sobre balão de $250 \mathrm{~mL}$;

b) Lavou-se com porções sucessivas de água destilada, tendo o cuidado de promover a suspensão da amostra; procedeu-se a extração até quase completar $250 \mathrm{~mL}$. Nos filtrados que apresentaram turbidez, foram adicionados $2 \mathrm{~mL}$ de solução de $\mathrm{HNO}_{3}(1+1)$;

c) Completou-se o volume.

d) Foi preparada uma prova em branco.

\subsection{Teor de micronutrientes solúvel em solução de ácido cítrico a $2 \%$}

A solução de ácido cítrico a $2 \%$ (AC) foi preparada dissolvendo-se $20,0 \mathrm{~g}$ de ácido cítrico cristalizado em água destilada. Transferiu-se para balão volumétrico de $1 \mathrm{~L}$ e completou-se o volume.

a) Transferiu-se $1,0000 \mathrm{~g}$ da amostra para erlenmeyer de $250 \mathrm{~mL}$, adicionaram-se 100 $\mathrm{mL}$ da solução de ácido cítrico a $2 \%$ e tampou-se com rolha de borracha;

b) Colocou-se em agitador tipo Wagner e agitou-se por 1 hora, a 30-40 rpm;

c) Transferiu-se o conteúdo do erlenmeyer para balão de $250 \mathrm{~mL}$, completando-se o volume com água destilada, deixando em repouso para decantar. Usou-se o sobrenadante para as determinações.

d) Foi preparada uma prova em branco.

\subsection{Teor de micronutrientes solúvel em solução neutra de citrato de amônio $(1+9)$}

A solução neutra de citrato de amônio $(1+9)$ - (CNA) foi preparada dissolvendose $370 \mathrm{~g}$ de ácido cítrico cristalizado em 1,5 L de água destilada e adicionando-se 345 
$\mathrm{mL}$ de solução de hidróxido de amônio. Determinou-se o $\mathrm{pH}$ potenciometricamente, ajustando à 7,0 com hidróxido de amônio $(1+7)$. Acertou-se a densidade para 1,09 , à temperatura de $20^{\circ} \mathrm{C}$, com água destilada. Em balão volumétrico de $1 \mathrm{~L}$ adicionou-se $100 \mathrm{~mL}$ dessa solução e completou-se o volume.

a) Transferiu-se $1,0000 \mathrm{~g}$ da amostra para erlenmeyer de $250 \mathrm{~mL}$, adicionaram-se 100 $\mathrm{mL}$ da solução neutra de citrato de amônio $(1+9)$ e tampou-se com rolha de borracha;

b) Colocou-se em agitador tipo Wagner e agitou-se por 1 hora, a 30-40 rpm;

c) Transferiu-se o conteúdo do erlenmeyer para balão de $250 \mathrm{~mL}$, completando-se o volume com água destilada, deixando em repouso para decantar. Usou-se o sobrenadante para as determinações.

d) Foi preparada uma prova em branco.

\subsection{Teor de micronutrientes solúvel em solução de DTPA $0,005 \mathrm{~mol} \mathrm{~L}^{-1}$}

A solução de DTPA utilizada foi a mesma proposta por Lindsay \& Norvell (1978) e que é utilizada atualmente para a extração de micronutrientes metálicos disponíveis de solos, pelo princípio da quelação. A única diferença dessa metodologia aqui proposta é a mudança da relação entre a massa da amostra com o extrator. Para solo a relação utilizada é de 1:2, enquanto para fertilizante, por ter uma concentração bem maior de micronutrientes, é proposta a relação $1: 100$.

O preparo da solução de DTPA $0,005 \mathrm{~mol} \mathrm{~L}^{-1}$ foi feito dissolvendo-se $1,96 \mathrm{~g}$ de DTPA num copo com aproximadamente $200 \mathrm{~mL}$ de água deionizada, acrescentando-se 14,9 mL de trietanolamina e, em seguida, $1,47 \mathrm{~g}$ de cloreto de cálcio $\left(\mathrm{CaCl}_{2} .2 \mathrm{H}_{2} \mathrm{O}\right)$. Transferiu-se para balão volumétrico de $1 \mathrm{~L}$, e o volume foi completado com água deionizada. $\mathrm{O}$ pH da solução foi corrigido para 7,3 através do uso de ácido clorídrico 4 $\mathrm{mol} \mathrm{L} \mathrm{L}^{-1}$.

a) Transferiu-se $1,0000 \mathrm{~g}$ da amostra para erlenmeyer de $250 \mathrm{~mL}$, adicionaram-se 100 $\mathrm{mL}$ da solução de DTPA $0,005 \mathrm{~mol} \mathrm{~L}^{-1}$ e tampou-se com rolha de borracha; 
b) Colocou-se em agitador tipo Wagner e agitou-se por 1 hora, a 30-40 rpm;

c) Transferiu-se o conteúdo do erlenmeyer para balão de $250 \mathrm{~mL}$, completou-se o volume com água destilada, deixando em repouso para decantar. Usou-se o sobrenadante para as determinações.

d) Foi preparada uma prova em branco.

\subsection{Teor de micronutrientes solúvel em solução de EDTA $0,005 \mathrm{~mol} \mathrm{~L}^{-1}$.}

A solução de EDTA foi preparada dissolvendo-se $1,86 \mathrm{~g}$ de EDTA num copo com aproximadamente $200 \mathrm{~mL}$ de água deionizada, acrescentando-se $14,9 \mathrm{~mL}$ de trietanolamina e, em seguida, $1,47 \mathrm{~g}$ de cloreto de cálcio $\left(\mathrm{CaCl}_{2} .2 \mathrm{H}_{2} \mathrm{O}\right)$. Transferiu-se para balão volumétrico de $1 \mathrm{~L}$, e o volume foi completado com água deionizada. $\mathrm{O} \mathrm{pH}$ da solução foi corrigido para 9,3 através do uso de hidróxido de sódio concentrado.

a) Transferiu-se $1,0000 \mathrm{~g}$ da amostra para erlenmeyer de $250 \mathrm{~mL}$, adicionou-se 100 $\mathrm{mL}$ da solução de EDTA $0,005 \mathrm{~mol} \mathrm{~L}^{-1}$ e tampou-se com rolha de borracha;

b) Colocou-se em agitador tipo Wagner e agitou-se por 1 hora, a 30-40 rpm;

c) Transferiu-se o conteúdo do erlenmeyer para balão de $250 \mathrm{~mL}$, completando-se o volume com água destilada, deixando-se em repouso para decantar. Usou-se o sobrenadante para as determinações.

d) Foi preparada uma prova em branco.

\subsubsection{Determinações}

As determinações de $\mathrm{Cu}, \mathrm{Fe}, \mathrm{Mn}$ e $\mathrm{Zn}$, em todos os extratos, foram feitas por espectrofotometria de absorção atômica, as de B segundo metodologia proposta pela Association of Official Analytical Chemists (1984), e as de Mo segundo Brasil (1983), todas após convenientes diluições com água destilada. 


\subsubsection{Avaliação do aproveitamento dos micronutrientes pelas plantas}

Foi realizada uma avaliação do aproveitamento dos micronutrientes pelas plantas, utilizando uma modificação do método de Neubauer \& Schneider, citado por Catani \& Bergamin Filho (1961). Na Figura 1 observam-se plantas em desenvolvimento durante o teste.

O método foi conduzido da seguinte maneira: em placas de Petri foram adicionadas camadas de sílica pré-lavadas com $\mathrm{HCl}(1+2)$, para se eliminar possiveis impurezas. O motivo da utilização da sílica, foi que o solo poderia fornecer micronutrientes para as plantas, o que dificultaria determinar se o micronutriente veio do solo ou do fertilizante. Cada placa recebeu uma dose de $1 \mathrm{mg}$ do fertilizante, de modo a fornecer a quantidade de cada elemento, conforme mostrado na Tabela 3. Estas quantidades foram baseadas nos teores totais de micronutrientes, determinados neste trabalho. Foram realizadas três repetições para cada fertilizante.

A seguir, foram plantadas 40 sementes de arroz cv. IAC 201, em cada placa, cobrindo-se com uma fina camada de silica. As placas foram irrigadas diariamente com $5 \mathrm{~mL}$ da solução nutritiva de Hogland e Arnon (1950), isenta de micronutrientes. Após 20-22 dias, as plantas foram colhidas por inteiro, lavadas, secas em estufa, pesadas, moídas, e submetidas à determinação dos teores de micronutrientes, segundo Malavolta et al. (1989). Determinaram-se, em cada amostra, apenas os micronutrientes garantidos pelos fabricantes. Com os valores da matéria seca produzida e os teores absorvidos, calcularam-se as quantidades de cada micronutriente acumuladas pelas plantas em cada tratamento.

\subsubsection{Tratamento estatístico}

Foram realizadas correlações entre os teores de micronutrientes garantidos pelos fabricantes e os teores totais encontrados, visando se identificar a validade dessas 
garantias. Também foram realizadas correlações entre o teor total de micronutrientes em cada fertilizante, e os teores solubilizados pelos diferentes extratores, visando identificar a coerência entre os teores presentes e a quantidade extraida. Essa determinação é importante pois correlações baixas podem indicar presença de micronutrientes em forma não disponivel, assim como correlações altas podem indicar extração de formas não solúveis. Essas correlações foram determinadas separadamente nos fertilizantes considerados solúveis e nos insolúveis. O motivo do uso dessas correlações foi o de se ter uma tendência geral de como é a extração realizada por cada extrator perante o grupo de fertilizantes.

No final foram realizadas correlações entre os teores de cada micronutriente extraído pelos diferentes extratores, e os teores encontrados nas plantas após a realização do teste de Neubauer \& Schneider, procurando-se identificar o melhor extrator para cada micronutriente. 


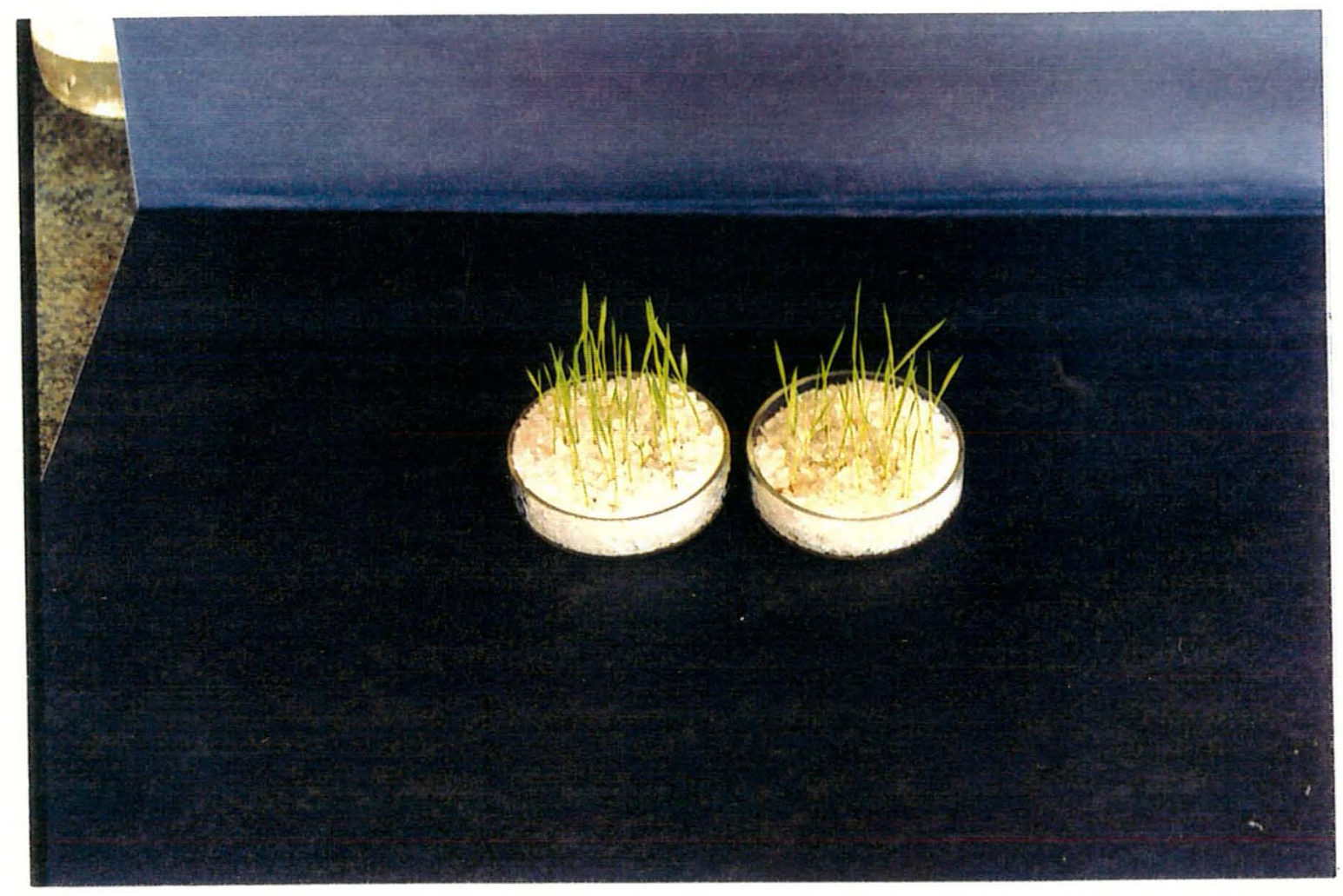

Figura 1 - Teste de Neubauer \& Schneider para avaliar a disponibilidade dos micronutrientes nos fertilizantes, dez dias após a germinação das plantas de arroz. 
Tabela 3 - Quantidade de cada micronutriente, em $\mu \mathrm{g}$, fornecido em cada tratamento, para avaliação da disponibilidade nos fertilizantes pelo método de Neubauer \& Schneider.

\begin{tabular}{|c|c|c|c|c|c|c|c|}
\hline \multirow{2}{*}{$N^{o}$} & \multirow{2}{*}{ Identificação } & $\mathrm{B}$ & $\mathrm{Cu}$ & $\mathrm{Fe}$ & $\mathrm{Mn}$ & Mo & $\mathrm{Zn}$ \\
\hline & & \multicolumn{6}{|c|}{ ug } \\
\hline 01 & FTE BR-12 & 19,8 & 09,3 & 101,6 & 68,2 & 1,50 & 205,3 \\
\hline 02 & FTE Sementes & 10,5 & - & - & 37,9 & 41,8 & 207,7 \\
\hline 03 & FTE JCO 2M & 19,2 & 51,0 & 50,7 & 87,0 & - & 41,4 \\
\hline 04 & FTE Centro Oeste & 30,0 & 10,0 & - & 63,8 & - & 179,3 \\
\hline 05 & Nutricitro 224 & 22,0 & - & - & 48,2 & $>$ & 224,8 \\
\hline 06 & Borogran - 10 & 93,6 & - & - & - & - & - \\
\hline 07 & Hidrozinc Frit 20 & - & - & - & - & - & 201,3 \\
\hline 08 & FTE Cerrrado S & 6,40 & 20,6 & - & 55,1 & 0,50 & 112,0 \\
\hline 09 & Zincogran 20 & - & - & - & - & & 200,5 \\
\hline 10 & FTE BR - 18 & 30,3 & 25,4 & - & - & 0,30 & 179,2 \\
\hline 11 & FTE BR - 8 & 21,8 & 15,3 & 59,4 & 103,6 & 0,60 & 88,1 \\
\hline 12 & Zincoman & - & 37,9 & - & 118,3 & - & 82,6 \\
\hline 13 & $\mathrm{Mib}-4$ & 31,0 & - & - & - & - & 172,7 \\
\hline 14 & $\mathrm{Mib}-3$ & 14,4 & 5,30 & 25,1 & 20,5 & 1,20 & 77,8 \\
\hline 15 & Mib - 3 & 16,8 & 7,90 & 41,1 & 21,2 & 1,20 & 88,1 \\
\hline 16 & Mib $-16 A$ & 30,2 & - & - & - & 15,7 & 304,0 \\
\hline 17 & Mib -28 & 21,3 & 13,8 & - & 80,2 & - & 145,6 \\
\hline 18 & Agrimax-12 & 17,0 & 10,2 & 90,6 & 19,9 & 1,10 & 86,8 \\
\hline 19 & Gran-o-zinc 20 & - & - & 113,0 & - & - & 181,1 \\
\hline 20 & Gran-o-bor 10 & 93,5 & - & - & - & - & - \\
\hline 21 & Agrimax CO 150 & 21,0 & 21,6 & - & 68,7 & - & 162,4 \\
\hline 22 & HGB 12 & 18,4 & 23,4 & - & 81,8 & - & 125,7 \\
\hline 23 & Plantzinco F IV & - & - & 8,30 & - & - & 542,5 \\
\hline 24 & Plantzinco F II & - & - & - & - & - & 200,8 \\
\hline 25 & Ulexita & 144,9 & - & $=$ & - & - & - \\
\hline 26 & Boro Importado & 151,0 & - & - & - & - & - \\
\hline 27 & Nitrex MS - 2 & 15,2 & 9,10 & - & 91,2 & - & 179,3 \\
\hline 28 & Copas - 8 (café) & 28,7 & - & - & - & - & 78,3 \\
\hline 29 & Copas - 9 (citrus) & 21,0 & - & - & 108,7 & - & 188,0 \\
\hline 30 & Nutri Oxi-Zn " $\mathrm{C}$ " & - & - & - & - & - & 107,5 \\
\hline
\end{tabular}




\section{RESULTADOS E DiSCUSSÃO}

\subsection{Avaliação química da disponibilidade dos micronutrientes}

A análise do resultados foi feita separadamente em dois grupos distintos: micronutrientes catiônicos (cobre, ferro, manganès e zinco) e aniônicos (boro e molibdênio).

\subsubsection{Micronutrientes catiônicos}

\subsubsection{Zinco}

$\mathrm{Na}$ Tabela 4 encontram-se os teores de zinco extraídos dos fertilizantes, por todos os extratores utilizados, e também os teores de zinco garantidos pelos produtores dos fertilizantes. É interessante observar a presença de teor total do elemento bem superior ao garantido, como as amostras 1 e 23 , por exemplo. Isto pode ser uma indicação da utilização de matéria-prima não considerada como fonte do elemento pela legislação na fabricação dos mesmos. Também os valores extraídos pelos diferentes extratores é bem variado, por isso foram realizadas correlações entre o teor total e o extraído por cada extrator, para se obter uma tendência de como é a ação do extrator perante uma série de fertilizantes. Também observou-se nos fertilizantes considerados solúveis (amostras de número 27 a 30), o teor total mais elevado de zinco presente em relação à garantia, com exceção da amostra 28; porém este teor mais elevado estava todo na forma solúvel nas amostras 27 e 29 . Na amostra 30 isto não ocorreu, porém as formas solúveis estavam de acordo com a garantia. 
Tabela 4 - Teores de zinco (\%) extraídos pelos diferentes extratores, nos fertilizantes com e sem garantia do elemento.

\begin{tabular}{|c|c|c|c|c|c|c|c|c|c|}
\hline \multirow{3}{*}{$\mathrm{N}^{\mathrm{o}}$} & \multirow{3}{*}{ Identificação } & \multirow{3}{*}{ Tipo } & \multicolumn{7}{|c|}{ Extrator } \\
\hline & & & garantia & $\begin{array}{l}\text { teor } \\
\text { total }\end{array}$ & água & $\begin{array}{l}\text { A.C. } \\
2 \% \\
\end{array}$ & $\begin{array}{l}\text { C.N.A } \\
1+9\end{array}$ & DTPA & EDTA \\
\hline & & & \multicolumn{7}{|c|}{ - $\%$ } \\
\hline \multicolumn{10}{|c|}{ Fertilizantes com garantia } \\
\hline 01 & FTE BR-12 & Frita & 9,0 & 20,53 & 1,18 & 6,51 & 3,43 & 5,25 & 2,50 \\
\hline 02 & FTE Sementes & Frita & 25,0 & 20,77 & 0,14 & 10,73 & 11,89 & 9,50 & 3,50 \\
\hline 03 & FTE JCO 2M & Frita & 5,0 & 4,14 & 0,00 & 2,78 & 0,48 & 0,75 & 0,20 \\
\hline 04 & FTE Centro Oeste & Frita & 15,0 & 17,93 & 0,71 & 5,63 & 2,55 & 5,35 & 3,80 \\
\hline 05 & Nutricitro 224 & Frita & 20,0 & 22,48 & 0,00 & 11,06 & 3,74 & 5,60 & 1,45 \\
\hline 07 & Hidrozinc Frit 20 & Frita & 20,0 & 20,13 & 7,98 & 11,51 & 5,20 & 8,95 & 5,20 \\
\hline 08 & FTE Cerrrado S & Frita & 13,0 & 11,20 & 0,00 & 8,16 & 1,11 & 1,70 & 0,65 \\
\hline 09 & Zincogran 20 & Frita & 20,0 & 20,05 & 2,46 & 13,81 & 9,34 & 3,50 & 3,55 \\
\hline 10 & FTE BR - 18 & Frita & 18,0 & 17,92 & 0,78 & 6,89 & 6,67 & 9,00 & 5,50 \\
\hline 11 & FTE BR - 8 & Frita & 7,0 & 8,81 & 0,00 & 3,66 & 0,51 & 1,30 & 0,30 \\
\hline 12 & Zincoman & Frita & 7,0 & 8,26 & 2,45 & 5,48 & 4,22 & 5,85 & 3,35 \\
\hline 13 & Mib - 4 & Frita & 20,0 & 17,27 & 6,83 & 7,60 & 3,23 & 9,95 & 6,10 \\
\hline 14 & Mib - 3 & Frita & 9,0 & 7,78 & 3,78 & 5,40 & 5,48 & 6,95 & 4,05 \\
\hline 15 & Mib - 3 & Frita & 9,0 & 8,81 & 0,00 & 4,47 & 2,95 & 5,80 & 1,55 \\
\hline 16 & Mib $-16 A$ & Frita & 25,0 & 30,40 & 6,37 & 9,32 & 6,64 & 3,90 & 4,10 \\
\hline 17 & Mib - 28 & Frita & 15,0 & 14,56 & 5,80 & 9,82 & 2,98 & 10,70 & 2,90 \\
\hline 18 & Agrimax-12 & Frita & 9,0 & 8,68 & 0,25 & 5,33 & 1,19 & 4,70 & 4,95 \\
\hline 19 & Gran-o-zinc 20 & Frita & 20,0 & 18,11 & 0,71 & 12,98 & 6,49 & 7,85 & 2,40 \\
\hline 21 & Agrimax CO 150 & Frita & 15,0 & 16,24 & 1,01 & 9,42 & 10,48 & 7,65 & 3,05 \\
\hline 22 & HGB 12 & Frita & 15,0 & 12,57 & 0,00 & 7,47 & 1,49 & 4,55 & 0,80 \\
\hline 23 & Plantzinco F IV & Frita & 40,0 & 54,25 & 0,01 & 33,90 & 17,44 & 7,30 & 1,90 \\
\hline 24 & Plantzinco F II & Frita & 20,0 & 20,08 & 1,14 & 10,00 & 9,04 & 7,25 & 3,05 \\
\hline 27 & Nitrex MS - 2 & Sais & 10,0 & 17,93 & 17,73 & 17,70 & 17,60 & 17,60 & 4,00 \\
\hline 28 & Copas - 8 (café) & Sais & 8,0 & 7,83 & 7,83 & 6,20 & 7,50 & 7,40 & 4,40 \\
\hline 29 & Copas - 9 (citrus) & Sais & 11,0 & 18,80 & 18,80 & 18,70 & 18,40 & 18,30 & 7,40 \\
\hline 30 & Nutri Oxi-Zn "C" & Quelato & 21,5 & 29,12 & 21,92 & 22,30 & 21,70 & 20,60 & 4,90 \\
\hline \multicolumn{10}{|c|}{ Fertilizantes sem garantia } \\
\hline 06 & Borogran - 10 & Frita & - & 1,03 & 0,00 & 0,88 & 0,53 & 0,80 & 0,65 \\
\hline 20 & Gran-o-bor 10 & Frita & - & 0,27 & 0,00 & 0,01 & 0,11 & 0,40 & 0,13 \\
\hline 25 & Ulexita & Boratos & - & 0,00 & 0,00 & 0,00 & 0,00 & 0,00 & 0,00 \\
\hline 26 & Boro Importado & Boratos & - & 0,00 & 0,00 & 0,00 & 0,00 & 0,00 & 0,00 \\
\hline
\end{tabular}

Quanto aos teores de zinco nos fertilizantes sem a garantia do elemento, pode-se observar, ainda na Tabela 4, que as amostras 6 e 20, do tipo fritas, apresentaram um 
pequeno teor do elemento, indicando que algum resíduo pode ter sido utilizado em sua fabricação. As amostras 25 e 26 nada apresentaram, o que era de se esperar, pois são boratos, produtos naturais.

Uma primeira comparação realizada foi entre a garantia de zinco nos fertilizantes e o total extraído de acordo com a legislação (Brasil, 1983), conforme se observa na Figura 2. O coeficiente de correlação encontrado foi de 0,92 , altamente significativo, indicando que o elemento foi adicionado ao fertilizante. $O$ valor do coeficiente angular da reta maior do que 1 (Tabela 5), indica uma tendência dos fertilizantes possuírem mais zinco do que é garantido.

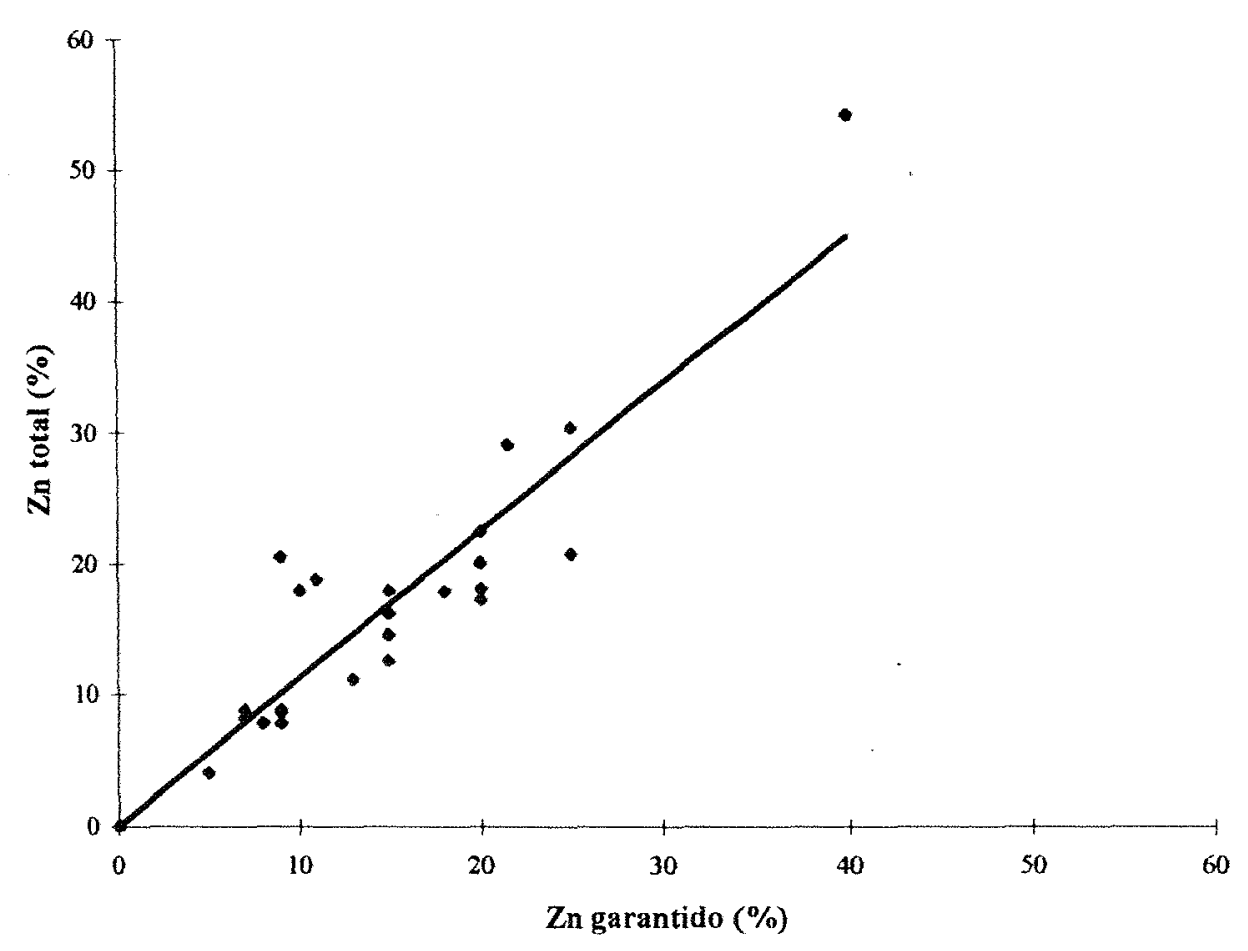

Figura 2 - Correlação apresentada entre os teores de zinco garantidos pelos fabricantes, e os teores totais extraídos com $\mathrm{HCl}$ concentrado 
As análises entre os teores totais e os teores solúveis por cada extrator foram consideradas de duas maneiras: comparação entre os teores extraídos dos fertilizantes considerados solúveis, e entre os teores nos fertilizantes tipo fritas, considerados de baixa solubilidade em água. Esta precaução foi tomada para que, no final, consiga-se definir um extrator que tenha atuado melhor na caracterização da solubilidade. É importante salientar, também, que essas correlações foram realizadas somente entre os fertilizantes que tinham garantia de zinco, pois a entrada dos outros produtos nos cálculos poderia gerar dados incorretos.

Tabela 5 - Valores dos coeficientes angulares da reta e dos coeficientes de correlação obtidos entre os teores garantidos pelos fabricantes e o teor total de zinco extraído por $\mathrm{HCl}$ concentrado dos fertilizantes, e entre o teor total e os teores solúveis pelos diferentes extratores, nas amostras de fertilizantes solúveis, e nas amostras de fertilizantes insolúveis em água.

\begin{tabular}{ccccccc}
\hline & \multicolumn{2}{c}{ Garantia x teor total } & \multicolumn{2}{c}{ Zinco total x solúveis } & \multicolumn{2}{c}{ Zinco total $\mathrm{x}$ insolúveis } \\
\cline { 2 - 7 } Extrator & $\begin{array}{c}\text { Coeficiente } \\
\text { angular da } \\
\text { reta }\end{array}$ & $\begin{array}{c}\text { Coeficientes } \\
\text { Correlação } \\
(\mathrm{r})\end{array}$ & $\begin{array}{c}\text { Coeficiente } \\
\text { angular da } \\
\text { reta }\end{array}$ & $\begin{array}{c}\text { Coeficientes } \\
\text { Correlação } \\
(\mathrm{r})\end{array}$ & $\begin{array}{c}\text { Coeficiente } \\
\text { angular da } \\
\text { reta }\end{array}$ & $\begin{array}{c}\text { Coeficientes } \\
\text { Correlação } \\
(\mathrm{r})\end{array}$ \\
\hline HCl conc. & 1,12 & $0,92^{* *}$ & - & - & - & - \\
Água & - & - & 0,86 & $0,97^{* *}$ & 0,08 & $0,12^{\text {ns }}$ \\
A.C. $2 \%$ & - & - & 0,86 & $0,97^{* *}$ & 0,53 & $0,91^{* *}$ \\
C.N.A. (1+9) & - & - & 0,85 & $0,97^{* *}$ & 0,31 & $0,78^{* *}$ \\
DTPA & - & - & 0,83 & $0,96^{* *}$ & 0,28 & $0,38^{\text {ns }}$ \\
EDTA & - & - & 0,33 & $0,69^{\text {ns }}$ & 013 & $0,21^{\text {ns }}$ \\
\hline
\end{tabular}

ns - Não significativo

* - Significativo ao nivel de $1 \%$ de probabilidade

$\mathrm{Na}$ Figura 3 encontram-se as correlações realizadas entre o teor total e os teores solubilizados pelos diferentes extratores, para os fertilizantes considerados solúveis. Observa-se que todos os extratores solubilizaram praticamente todo o zinco dos fertilizantes, podendo-se considerar que ele estava, então, na forma solúvel. Este comportamento só não ocorreu na presença do EDTA. Esta alta extração pode ser caracterizada pelos altos coeficientes angulares das retas apresentadas (Tabela 5), pois quanto mais próximo de 1,0 esse valor, maior a quantidade extraida em relação ao teor 
total. Os valores da amostra 30, já discutidos, diminuíram um pouco a inclinação das retas. A alta solubilização pela água é um indicativo da utilização de fontes solúveis de zinco nos fertilizantes. Quanto aos coeficientes de correlação altamente significativos apresentados pelos extratores água, AC, CNA e DTPA, pode-se dizer que a extração por eles realizada foi proporcional ao aumento do teor total de zinco; para o EDTA o valor foi não significativo, e isto associado à sua baixa extração de zinco solúvel, é um indicativo de sua baixa eficiência na determinação de zinco solúvel, nesta concentração e pH utilizados. Isto pode ter ocorrido devido a alguma precipitação causada pelo valor do pH da solução, apesar de Ringbom (1963) demonstrar uma boa complexação de zinco pelo EDTA na faixa de $\mathrm{pH}$ utilizado no trabalho.

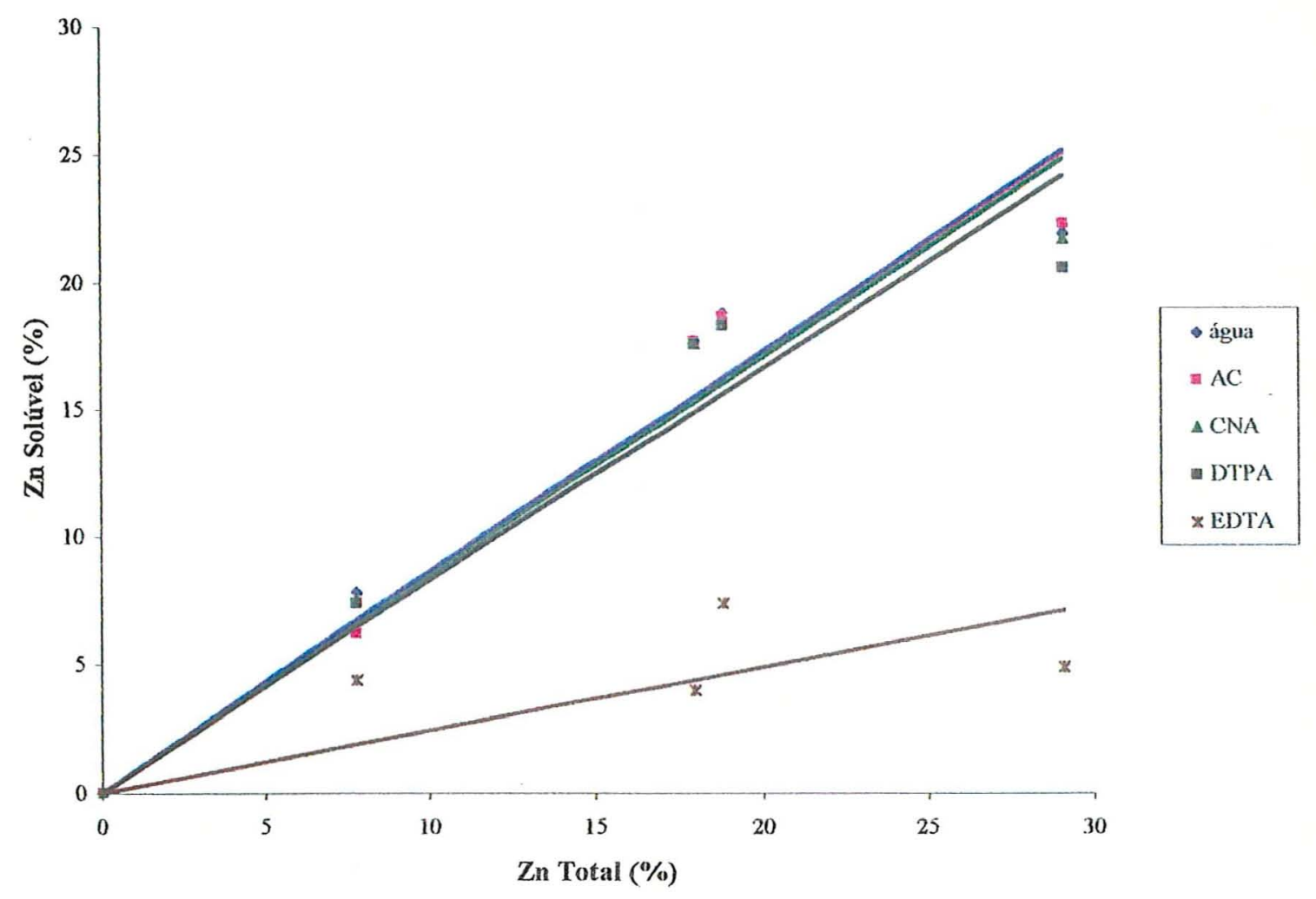

Figura 3 - Correlações apresentadas entre o teor total de zinco e os teores solubilizados pelos diferentes extratores, para os fertilizantes considerados solúveis. 


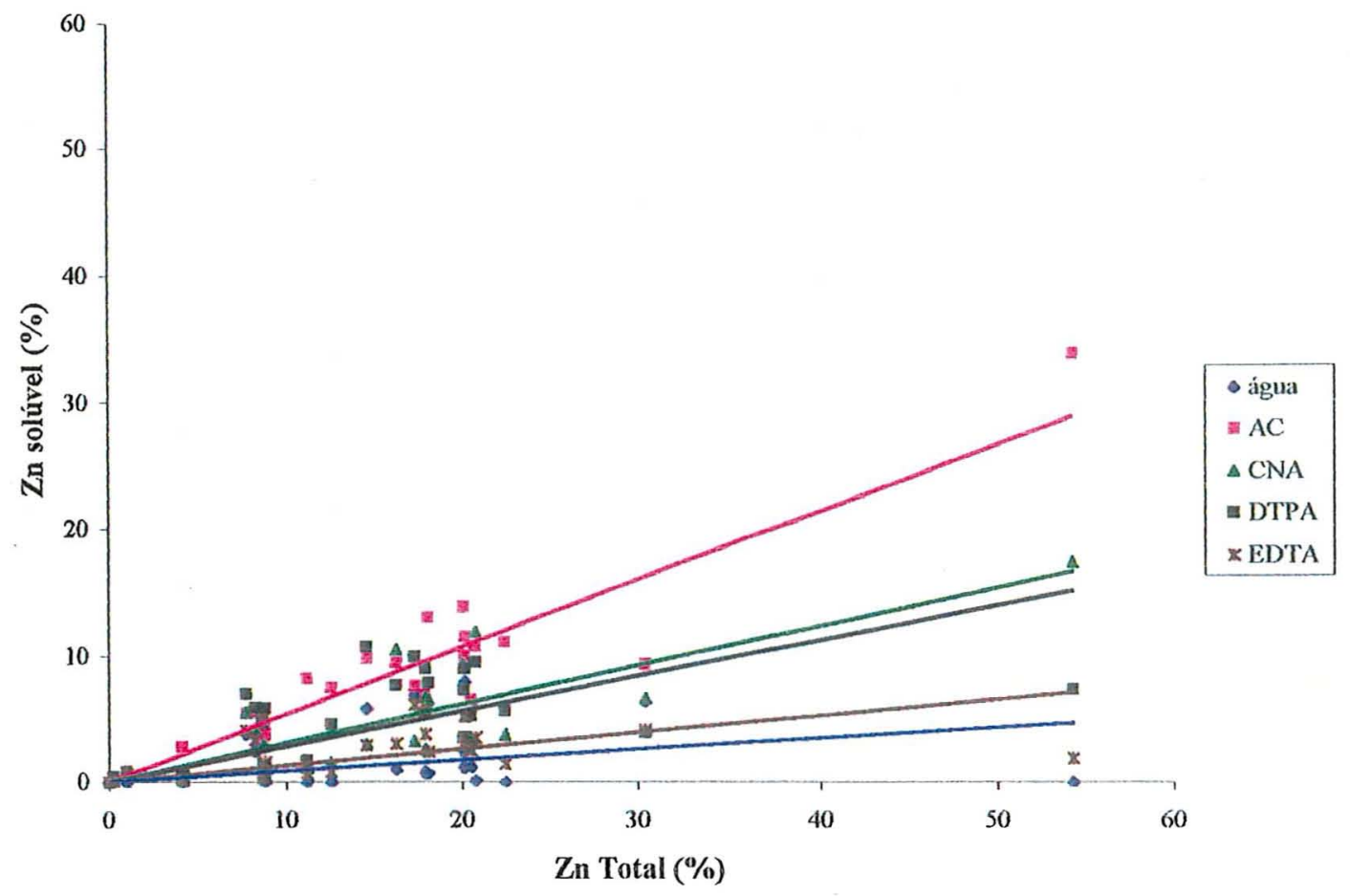

Figura 4 - Correlações apresentadas entre o teor total de zinco e os teores solubilizados pelos diferentes extratores, para os fertilizantes considerados insolúveis.

Analisando-se, agora, as comparações entre os teores totais de zinco e os teores extraídos pelos diferentes extratores para as fritas (Figura 4), conclui-se, pelos baixos coeficientes lineares das retas, apresentados na Tabela 5, que todos os extratores solubilizaram bem menos zinco em relação ao teor total presente. E observa-se três tendências diferenciadas de extração: o AC tendeu a extrair bem mais, seguido do CNA e DTPA, e com o EDTA e água extraindo menos. Quanto aos coeficientes de correlação (Tabela 5), somente o AC e o CNA foram significativos, e que aumentavam a extração à medida que aumentava o teor de zinco nos fertilizantes. Isto pode indicar que o extrator extraiu também formas insolúveis presentes. Uma explicação que pode ser dada ao valor $\mathrm{r}=0,91$ do extrator $\mathrm{AC}$, é que, devido a acidez elevada apresentada pelo mesmo, em torno de 2,3 (Alcarde \& Ponchio, 1979), está solubilizando formas pouco 
solúveis de zinco. Da mesma forma, o coeficiente de correlação não significativo apresentado pelo DTPA, por exemplo, pode ser devido aos diferentes materiais utilizados na fabricação dos fertilizantes, fazendo com que cada um tenha um teor diferente de zinco disponível.

Esta diferença de comportamento observada entre os extratores (Figuras 3 e 4) demonstra que foram diferentes na avaliação do zinco disponivel. Porém, é interessante sempre lembrar que somente as correlações entre o teor de zinco extraído pelos extratores e os teores absorvidos por plantas poderão facilitar a identificação dos extratores que melhor caracterizam a solubilidade de zinco nos fertilizantes.

\subsubsection{Ferro}

Os teores totais de ferro extraídos dos fertilizantes, os teores solúveis pelos extratores, assim como a garantia de ferro fornecida pelos fabricantes encontram-se listados na Tabela 6. A primeira constatação interessante quanto ao teor desse elemento nos fertilizantes é a sua alta concentração total, no geral, tanto nas amostras com, como nas sem garantia. Se levar-se em conta, por exemplo, as amostras 07 e 09, entre outras, observa-se a presença de uma alta concentração do elemento, mesmo sem ser garantido. Estes fertilizantes são fontes exclusivas de zinco, e este, provavelmente deve ter sido adicionado na forma de algum resíduo, rico em ferro. Também pode-se observar que o elemento, tanto nas amostra com garantia, como nas sem, praticamente não é extraído pela água, CNA, EDTA e DTPA, somente o AC extraiu um pouco. Pode-se concluir, portanto, que o ferro foi adicionado, no geral, em formas pouco solúveis aos fertilizantes estudados.

Uma correlação entre os teores de ferro garantidos pelos fabricantes, e o teor total determinado neste trabalho foi realizada, conforme se observa na Figura 5 . O valor obtido foi não significativo $(r=0,23)$. Pelos pontos plotados no gráfico observa-se dois grupos distintos de fertilizantes: um grupo em que os teores totais estão próximos da garantia, e outro em que os teores totais são bem superiores aos garantidos; 
provavelmente foi utilizado algum produto não considerado fertilizante no fornecimento de micronutrientes.

Tabela 6 - Teores de ferro (\%) extraídos pelos diferentes extratores, nos fertilizantes com e sem garantia do elemento.

\section{Extrator}

\begin{tabular}{|c|c|c|c|c|c|c|c|c|c|}
\hline \multirow{3}{*}{$N^{\mathbf{a}}$} & \multirow{3}{*}{ Identificação } & \multirow{3}{*}{ Tipo } & \\
\hline & & & garantia & $\begin{array}{l}\text { teor } \\
\text { total }\end{array}$ & água & $\begin{array}{c}\text { A.C. } \\
2 \%\end{array}$ & $\begin{array}{r}\text { C.N.A } \\
1+9 \\
\end{array}$ & DTPA & EDTA \\
\hline & & & \multicolumn{7}{|c|}{ \% } \\
\hline \multicolumn{10}{|c|}{ Fertilizantes com garantia } \\
\hline 01 & FTE BR-12 & Frita & 3,0 & 10,16 & 0,00 & 0,95 & 0,33 & 0,16 & 0,03 \\
\hline 03 & FTE JCO $2 \mathrm{M}$ & Frita & 5,0 & 5,07 & 0,00 & 0,71 & 0,05 & 0,04 & 0,01 \\
\hline 11 & FTE BR - 8 & Frita & 5,0 & 5,94 & 0,00 & 0,78 & 0,05 & 0,06 & 0,01 \\
\hline 14 & $\mathrm{Mib}-3$ & Frita & 3,0 & 2,51 & 0,01 & 0,79 & 0,13 & 0,01 & 0,02 \\
\hline 15 & $\mathrm{Mib}-3$ & Frita & 3,0 & 4,11 & 0,00 & 0,32 & 0,09 & 0,04 & 0,01 \\
\hline 18 & Agrimax-12 & Frita & 3,0 & 9,06 & 0,00 & 0,86 & 0,11 & 0,03 & 0,03 \\
\hline 19 & Gran-o-zinc 20 & Frita & 1,0 & 11,30 & 0,00 & 1,96 & 0,47 & 0,02 & 0,02 \\
\hline 23 & Plantzinco F IV & Frita & 1,0 & 0,83 & 0,00 & 0,28 & 0,10 & 0,02 & 0,01 \\
\hline \multicolumn{10}{|c|}{ Fertilizantes sem garantia } \\
\hline 02 & FTE Sementes & Frita & - & 2,83 & 0,00 & 0,53 & 0,14 & 0,02 & 0,03 \\
\hline 04 & FTE Centro Oeste & Frita & - & 3,64 & 0,00 & 1,04 & 0,12 & 0,05 & 0,03 \\
\hline 05 & Nutricitro 224 & Frita & - & 4,20 & 0,00 & 1,55 & 0,04 & 0,03 & 0,01 \\
\hline 06 & Borogran - 10 & Frita & - & 1,76 & 0,00 & 0,14 & 0,06 & 0,08 & 0,03 \\
\hline 07 & Hidrozinc Frit 20 & Frita & - & 15,90 & 0,10 & 0,31 & 0,11 & 0,05 & 0,02 \\
\hline 08 & FTE Cerrrado S & Frita & - & 5,91 & 0,00 & 1,69 & 0,05 & 0,07 & 0,01 \\
\hline 09 & Zincogran 20 & Frita & - & 24,67 & 0,25 & 3,25 & 1,79 & 0,24 & 0,16 \\
\hline 10 & FTE BR - I9 & Frita & - & 7,79 & 0,00 & 0,93 & 0,46 & 0,07 & 0,05 \\
\hline 12 & Zincoman & Frita & - & 9,47 & 0,00 & 1,00 & 0,35 & 0,01 & 0,01 \\
\hline 13 & $\mathrm{Mib}-4$ & Frita & - & 2,22 & 0,01 & 0,50 & 0,21 & 0,02 & 0,01 \\
\hline 16 & $\mathrm{Mib}-16 \mathrm{~A}$ & Frita & - & 4,86 & 0,06 & 1,15 & 0,63 & 0,10 & 0,03 \\
\hline 17 & $\mathrm{Mib}-28$ & Frita & - & 3,97 & 0,07 & 1,37 & 0,36 & 0,03 & 0,03 \\
\hline 20 & Gran-o-bor 10 & Frita & - & 0,50 & 0,00 & 0,00 & 0,04 & 0,03 & 0,02 \\
\hline 21 & Agrimax CO 150 & Frita & - & 3,53 & 0,00 & 0,56 & 0,15 & 0,02 & 0,01 \\
\hline 22 & HGB 12 & Frita & - & 2,41 & 0,00 & 0,82 & 0,09 & 0,07 & 0,01 \\
\hline 24 & Plantzinco F II & Frita & - & 8,08 & 0,00 & 1,03 & 0,09 & 0,01 & 0,01 \\
\hline 25 & Ulexita & Boratos & - & 1,65 & 0,00 & 0,02 & 0,00 & 0,01 & 0,01 \\
\hline 26 & Boro Importado & Boratos & - & 0,17 & 0,00 & 0,23 & 0,06 & 0,17 & 0,01 \\
\hline 27 & Nitrex MS - 2 & Sais & - & 0,26 & 0,18 & 0,24 & 0,24 & 0,15 & 0,01 \\
\hline 28 & Copas - 8 (café) & Sais & - & 0,13 & 0,05 & 0,06 & 0,06 & 0,06 & 0,01 \\
\hline 29 & Copas - 9 (citrus) & Sais & - & 0,18 & 0,11 & 0,13 & 0,11 & 0,08 & 0,00 \\
\hline 30 & Nutri Oxi-Zn "C" & Quelato & - & 0,04 & 0,01 & 0,02 & 0,02 & 0,01 & 0,00 \\
\hline
\end{tabular}




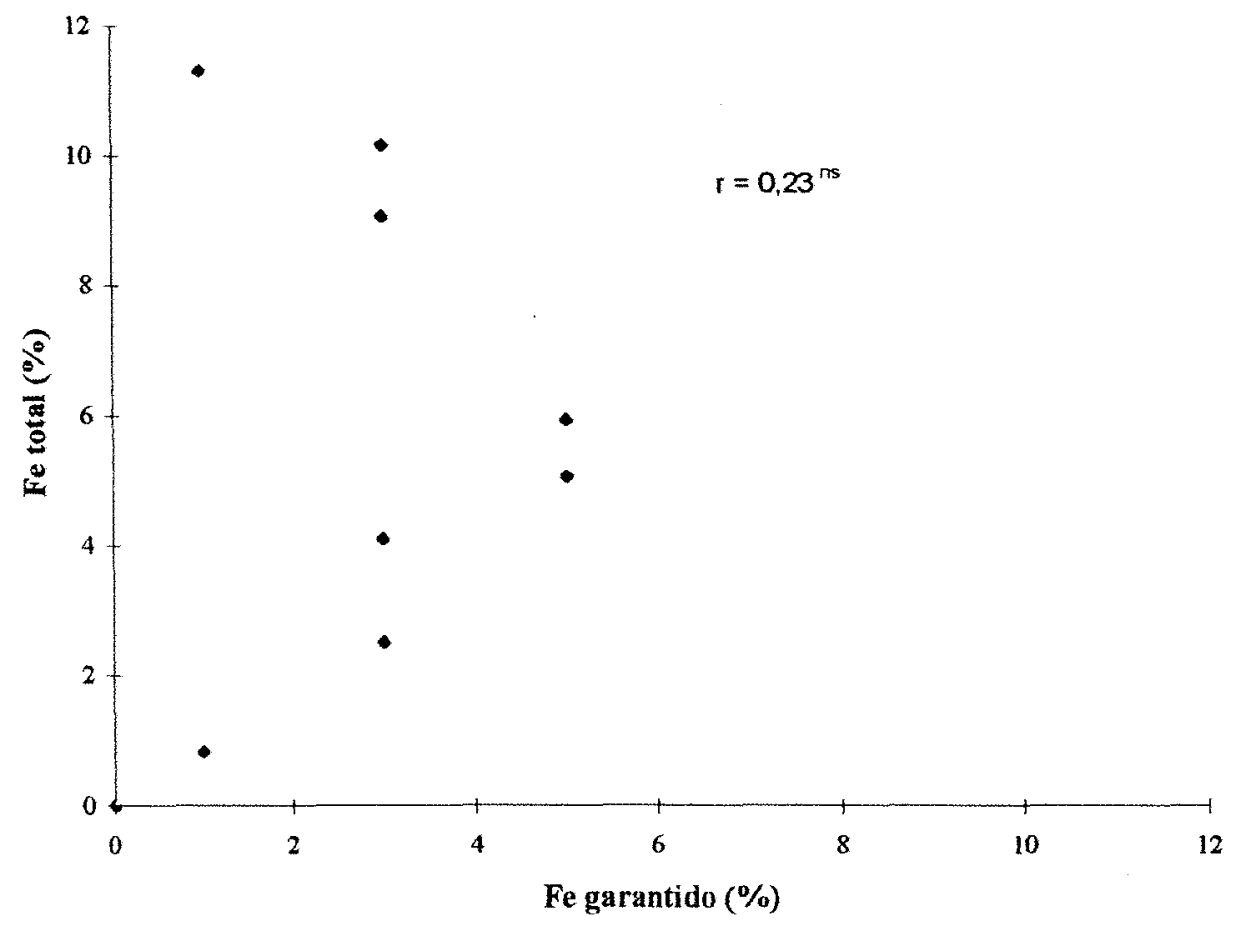

Figura 5 - Correlação apresentada entre os teores de ferro garantidos pelos fabricantes, e os teores totais extraídos com $\mathrm{HCl}$ concentrado

A solubilização do ferro por todos os extratores, em relação aos teores totais presentes é mostrada na Figura 6. É importante salientar que considerou-se apenas os fertilizantes com garantia do elemento, pois o objetivo inicial do presente trabalho é o de considerar a solubilidade dos elementos garantidos. Constata-se que os extratores água, DTPA e EDTA não conseguiram solubilizar ferro. Ringbom (1963) e Lindsay \& Norvell (1978) demostraram a capacidade de quelatação do ferro disponível em solução pelo DTPA e EDTA. A solubilidade igual a zero em água é um indicativo da utilização de produtos com ferro indisponivel, provavelmente metálico, na produção dos fertilizantes. $\mathrm{O}$ extrator $\mathrm{AC}$ foi o que mais conseguiu solubilizar ferro; sua acidez (Alcarde \& Ponchio, 1979) provavelmente favoreceu a liberação de ferro insolúvel à solução. O extrator CNA extraiu uma quantidade muito pequena de ferro. É interessante observar 
que os coeficientes de correlação entre o teor total presente nos fertilizantes e o extraído por esses dois últimos extratores (Tabela 7) foi significativa, e à medida que aumentava o teor total de ferro presente aumentava a solubilização. Isto pode ser mais uma demonstração da possível extração de ferro insolúvel por esses extratores no estudo do elemento ferro não foi feito uso de nenhum fertilizante com presença de ferro considerado solúvel, pois não foi encontrado no mercado nenhum produto com essa característica.

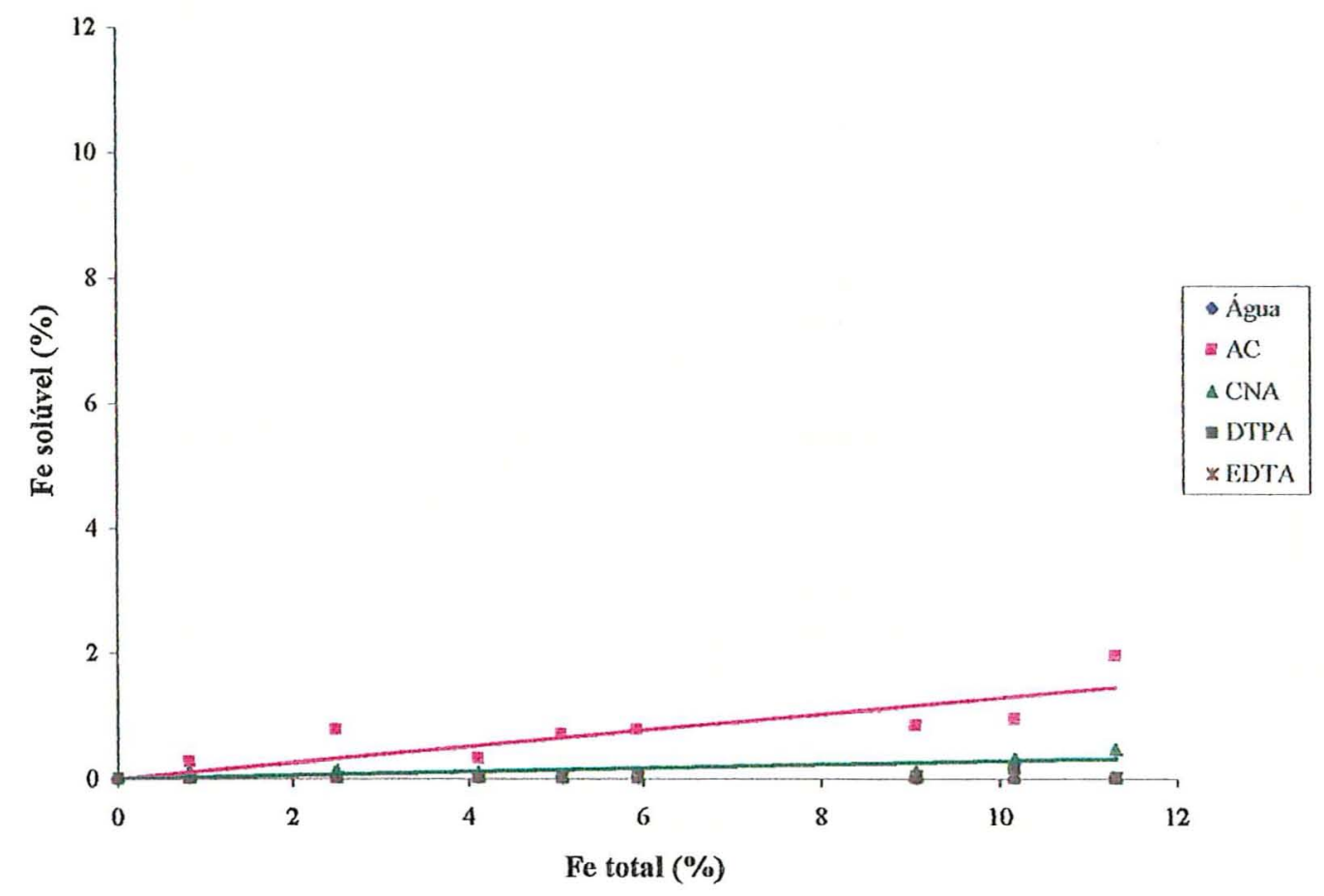

Figura 6 - Correlações apresentadas entre o teor total de ferro e os teores solubilizados pelos diferentes extratores, para os fertilizantes considerados insolúveis. 
Tabela 7 - Valores dos coeficientes angulares da reta e dos coeficientes de correlação obtidos entre o teor total de ferro extraído por $\mathrm{HCl}$ concentrado dos fertilizantes e os teores solúveis pelos diferentes extratores e nas amostras de fertilizantes insolúveis em água.

\begin{tabular}{ccc}
\hline \multirow{2}{*}{ Extrator } & \multicolumn{3}{c}{ Ferro total x insolúveis } \\
\cline { 2 - 3 } & \multicolumn{3}{c}{ Coeficiente angular da reta } & Coeficientes de Correlação (r) \\
\hline Agua & 0,00 & $0,24^{\text {ns }}$ \\
A.C. $2 \%$ & 0,13 & $0,84^{* *}$ \\
C.N.A. $(1+9)$ & 0,03 & $0,75^{*}$ \\
DTPA & 0,00 & $0,54^{\mathrm{ns}}$ \\
EDTA & 0,00 & $0,58^{\mathrm{ns}}$ \\
\hline ns - Não significativo & & \\
* - Significativo ao nivet de $5 \%$ de probabilidade & & \\
** - Significativo ao nivel de $1 \%$ de probabilidade &
\end{tabular}

\subsubsection{Manganês}

Na Tabela 8 são apresentados os teores totais de manganês determinados de acordo com Brasil (1983), e os teores solúveis nos diversos extratores testados, tanto para os fertilizantes com, como nos sem garantia do elemento. Nestes últimos, observase a presença de manganês em alto teor em algumas amostras, como na número 16 , que apresentou $26,4 \%$ do elemento. Esta amostra é um fertilizante com garantia de alto teor de zinco (25\%). Fica uma evidência de que foi utilizado algum material não considerado fertilizante, com alto teor de manganês e zinco para fornecimento do zinco. Também as amostras 10,13 e 24 ocorreu coisa semelhante.

A correlação entre o teor de manganês garantido pelos fabricantes e o teor total extraído é apresentada na Figura 7. Apesar de altamente significativa (Tabela 9), observa-se uma certa dispersão dos pontos, podendo ser uma indicação do uso de diversas fontes distintas na adição do elemento aos fertilizantes. 
Tabela 8 - Teores de manganês (\%) extraídos pelos diferentes extratores, nos fertilizantes com e sem garantia do elemento.

\begin{tabular}{|c|c|c|c|c|c|c|c|c|c|}
\hline \multirow{3}{*}{ № } & \multirow{3}{*}{ Identificação } & \multirow{3}{*}{ Tipo } & \multicolumn{7}{|c|}{ Extrator } \\
\hline & & & garantia & $\begin{array}{l}\text { teor } \\
\text { total }\end{array}$ & água & $\begin{array}{l}\text { A.C. } \\
2 \% \\
\end{array}$ & $\begin{array}{c}\text { C.N.A } \\
1+9 \\
\end{array}$ & DTPA & EDTA \\
\hline & & & \multicolumn{7}{|c|}{ 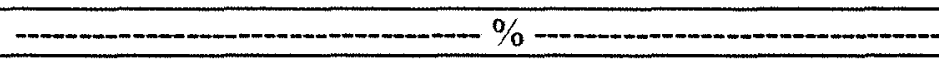 } \\
\hline \multicolumn{10}{|c|}{ Fertilizantes com garantia } \\
\hline 01 & FTE BR-12 & Frita & 2,0 & 6,82 & 0,92 & 3,35 & 1,47 & 0,67 & 0,37 \\
\hline 02 & FTE Sementes & Frita & 2,0 & 3,79 & 0,01 & 0,73 & 0,59 & 0,05 & 0,00 \\
\hline 03 & FTE JCO 2M & Frita & 8,0 & 8,70 & 0,00 & 2,69 & 0,29 & 0,31 & 0,00 \\
\hline 04 & FTE Centro Oeste & Frita & 10,0 & 6,38 & 0,99 & 3,24 & 0,24 & 1,39 & 0,17 \\
\hline 05 & Nutricitro 224 & Frita & 4,0 & 4,82 & 0,01 & 2,08 & 0,25 & 0,43 & 0,01 \\
\hline 08 & FTE Cerrrado S & Frita & 6,0 & 5,51 & 0,00 & 1,56 & 0,25 & 0,27 & 0,00 \\
\hline 11 & FTE BR - 8 & Frita & 10,0 & 10,36 & 0,00 & 1,51 & 0,10 & 0,22 & 0,00 \\
\hline 12 & Zincoman & Frita & 15,0 & 11,83 & 2,36 & 4,18 & 2,27 & 2,37 & 0,42 \\
\hline 14 & $\mathrm{Mib}-3$ & Frita & 2,0 & 2,05 & 1,42 & 1,88 & 0,28 & 0,64 & 0,14 \\
\hline 15 & Mib - 3 & Frita & 2,0 & 2,12 & 1,00 & 0,85 & 0,50 & 0,45 & 0,08 \\
\hline 17 & $\mathrm{Mib}-28$ & Frita & 10,0 & 8,02 & 3,20 & 3,98 & 1,17 & 1,96 & 0,69 \\
\hline 18 & Agrimax-12 & Frita & 2,0 & 1,99 & 0,09 & 0,54 & 0,03 & 0,08 & 0,02 \\
\hline 21 & Agrimax CO 150 & Frita & 10,0 & 6,87 & 0,52 & 2,52 & 0,44 & 0,48 & 0,10 \\
\hline 22 & HGB 12 & Frita & 10,0 & 8,18 & 0,00 & 4,58 & 0,25 & 0,72 & 0,04 \\
\hline 27 & Nitrex MS - 2 & Sais & 8,0 & 9,12 & 7,79 & 6,17 & 6,42 & 8,27 & 2,22 \\
\hline 29 & Copas - 9 (citrus) & Sais & 9,0 & 10,87 & 9,57 & 10,80 & 10,60 & 10,80 & 1,69 \\
\hline \multicolumn{10}{|c|}{ Fertilizantes sem garantia } \\
\hline 06 & Borogran - 10 & Frita & - & 0,17 & 0,01 & 0,03 & 0,00 & 0,04 & 0,01 \\
\hline 07 & Hidrozinc Frit 20 & Frita & - & 0,00 & 0,00 & 0,00 & 0,00 & 0,00 & 0,00 \\
\hline 09 & Zincogran 20 & Frita & - & 1,08 & 0,15 & 0,26 & 0,17 & 0,18 & 0,03 \\
\hline 10 & FTE BR - 18 & Frita & - & 2,23 & 0,41 & 0,73 & 0,40 & 0,36 & 0,09 \\
\hline 13 & Mib - 4 & Frita & - & 2,97 & 1,35 & 1,50 & 0,33 & 1,23 & 0,13 \\
\hline 16 & Mib - 16A & Frita & - & 26,40 & 2,49 & 0,89 & 0,52 & 1,22 & 0,05 \\
\hline 19 & Gran-o-zinc 20 & Frita & - & 0,50 & 0,04 & 0,16 & 0,04 & 0,05 & 0,01 \\
\hline 20 & Gran-o-bor 10 & Frita & - & 0,15 & 0,01 & 0,02 & 0,00 & 0,01 & 0,00 \\
\hline 23 & Plantzinco F IV & Frita & - & 0,44 & 0,00 & 0,31 & 0,06 & 0,03 & 0,00 \\
\hline 24 & Plantzinco F II & Frita & - & 3,61 & 0,02 & 1,43 & 0,27 & 0,03 & 0,00 \\
\hline 25 & Ulexita & Boratos & - & 0,00 & 0,00 & 0,00 & 0,00 & 0,00 & 0,00 \\
\hline 26 & Boro Importado & Boratos & - & 0,00 & 0,00 & 0,00 & 0,00 & 0,00 & 0,00 \\
\hline 28 & Copas - 8 (café) & Sais & $=$ & 0,03 & 0,03 & 0,02 & 0,02 & 0,03 & 0,00 \\
\hline 30 & Nutri Oxi-Zn "C" & Quelato & - & 0,00 & 0,00 & 0,00 & 0,00 & 0,00 & 0,00 \\
\hline
\end{tabular}




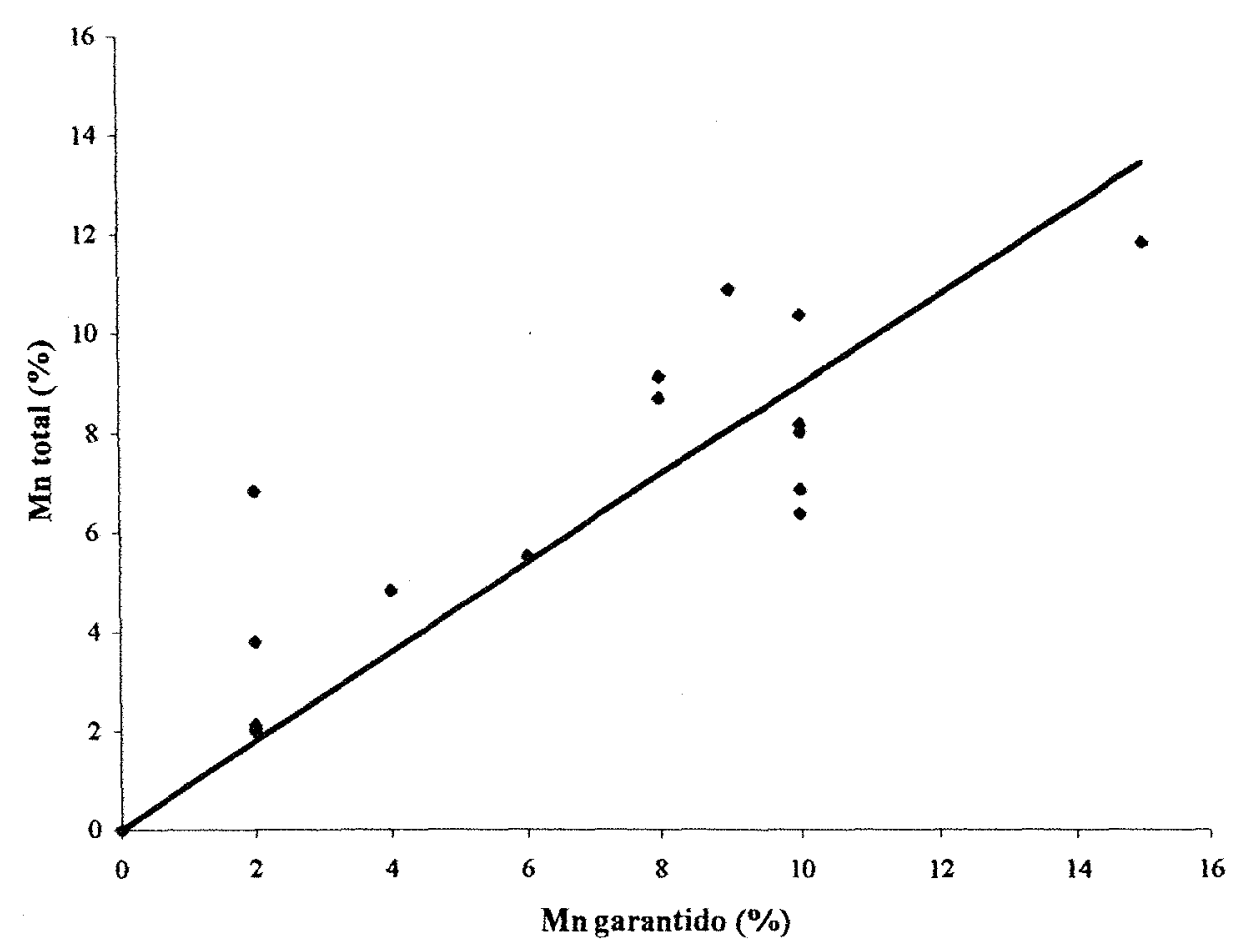

Figura 7 -Correlação apresentada entre os teores de manganês garantidos pelos fabricantes, e os teores totais extraídos com $\mathrm{HCl}$ concentrado

Considerando o teor extraído dos fertilizantes solúveis (Figura 8), observa-se que o DTPA tendeu extrair mais, seguido do AC, CNA e água, praticamente idênticos, e com o EDTA extraindo bem menos; estes fatos podem ser comprovados pelos valores do coeficiente angular obtidos para cada reta (Tabela 9). A efetividade do $\mathrm{AC}, \mathrm{CNA}$ e DTPA em solubilizar manganês é demonstrada em Ringbom (1963). A alta extração realizada pela água comprova que foram usadas fontes bastante solúveis no fornecimento de manganês aos fertilizantes. Os altos e significativos coeficientes de correlação apresentados pelos extratores DTPA e água (Tabela 9) indicam uma coerência na extração do manganês, isto é, aumentando o teor total aumenta a extração. Para o $\mathrm{AC}, \mathrm{CNA}$ e EDTA a correlação foi não significativa. $\mathrm{O}$ pequeno número de amostras testadas deixa um pouco em dúvida a validade desse fato, para o AC e CNA. 
Porém, para o EDTA, a baixa eficácia na extração por si só já desqualifica o extrator como eficiente na determinação de manganês disponível em fertilizantes, no $\mathrm{pH}$ e concentração testados.

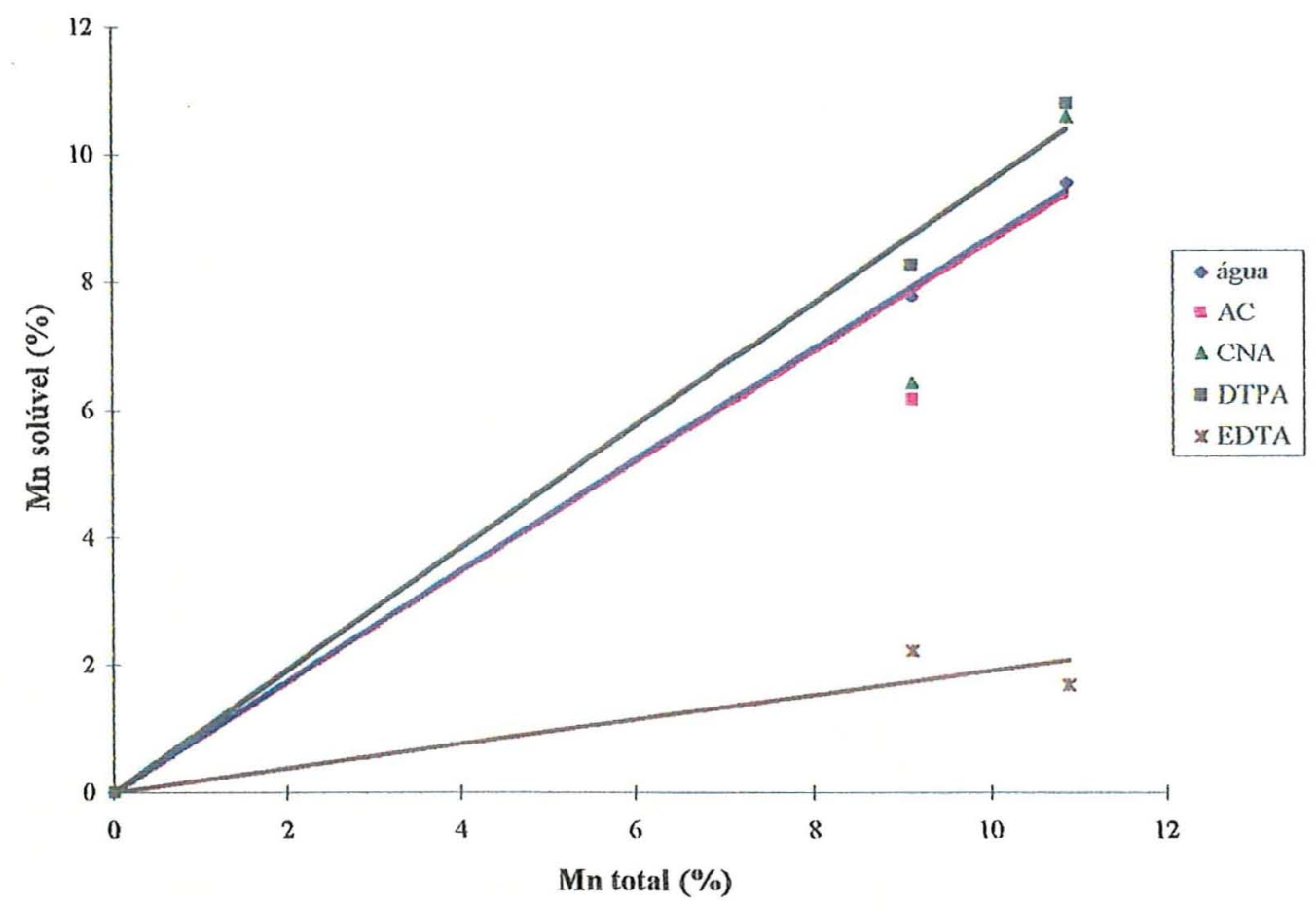

Figura 8 - Correlações apresentadas entre o teor total de manganês e os teores solubilizados pelos diferentes extratores, para os fertilizantes considerados solúveis. 
Tabela 9 - Valores dos coeficientes angulares da reta e dos coeficientes de correlação obtidos entre os teores garantidos pelos fabricantes e o teor total de manganês extraido por $\mathrm{HCl}$ concentrado dos fertilizantes, e entre o teor total e os teores solúveis pelos diferentes extratores, nas amostras de fertilizantes solúveis, e nas amostras de fertilizantes insolúveis em água.

\begin{tabular}{ccccccc}
\hline \multirow{2}{*}{ Extrator } & \multicolumn{2}{c}{ Garantia x teor total } & \multicolumn{2}{c}{ Manganês total x solúveis } & \multicolumn{2}{c}{ Manganês total x insolúveis } \\
\cline { 2 - 7 } & $\begin{array}{c}\text { Coeficient } \\
\text { e angular } \\
\text { da reta }\end{array}$ & $\begin{array}{c}\text { Coeficientes } \\
\text { Correlação } \\
(\mathrm{r})\end{array}$ & $\begin{array}{c}\text { Coeficiente } \\
\text { angular da } \\
\text { reta }\end{array}$ & $\begin{array}{c}\text { Coeficientes } \\
\text { Correlação } \\
(\mathrm{r})\end{array}$ & $\begin{array}{c}\text { Coeficiente } \\
\text { angular da } \\
\text { reta }\end{array}$ & $\begin{array}{c}\text { Coeficientes } \\
\text { Correlação } \\
(\mathrm{r})\end{array}$ \\
\hline HCl conc. & 0,90 & $0,87^{* *}$ & - & - & - & - \\
Água & - & - & 0,87 & $0,99^{* *}$ & 0,11 & $0,29^{\text {ns }}$ \\
A.C. $2 \%$ & - & - & 0,86 & $0,96^{\text {ns }}$ & 0,37 & $0,75^{* *}$ \\
C.N.A. $(1+9)$ & - & - & 0,86 & $0,97^{\text {ns }}$ & 0,09 & $0,53^{*}$ \\
DTPA & - & - & 0,96 & $0,99^{* *}$ & 0,12 & $0,57^{*}$ \\
EDTA & - & - & 0,19 & $0,93^{\text {ns }}$ & 0,02 & $0,39^{\text {ns }}$ \\
\hline
\end{tabular}

ns - Não signiticativo

* Significativo ao nivel de $\$ \%$ de probabilidade

** - Significativo ao nivel de $1 \%$ de probabilidade

Avaliando-se, agora, a solubilização do manganês das fontes menos solúveis (Figura 9), observa-se que o manganès teve uma baixa extração por todos os extratores testados, evidenciado pelos baixos coeficientes angulares das retas, apresentados na Tabela 9. Isto é uma indicação da utilização de fontes de baixa solubilidade, até resíduos metálicos na fabricação dos fertilizantes. Houve tendência semelhante de extração por parte dos extratores água, CNA e DTPA, em média extraindo $11 \%$ do manganês total. Também os coeficientes de correlação para esses três extratores foram baixos e não significativos, indicando extração não coerente das diferentes fontes. Isto é outra evidência à adição de produtos não contemplados como fonte de manganês pela legislação. Quanto a maior extração realizada pelo $\mathrm{AC}$, e com coeficiente de correlação também superior, e significativo, fica novamente a suspeita se acidez elevada do extrator (Alcarde \& Ponchio, 1979) não está favorecendo a liberação de manganês insolúvel nos à solução. A extração praticamente nula por parte do EDTA reforça a baixa eficiência desse extrator na solubilização do manganês dos fertilizantes. 


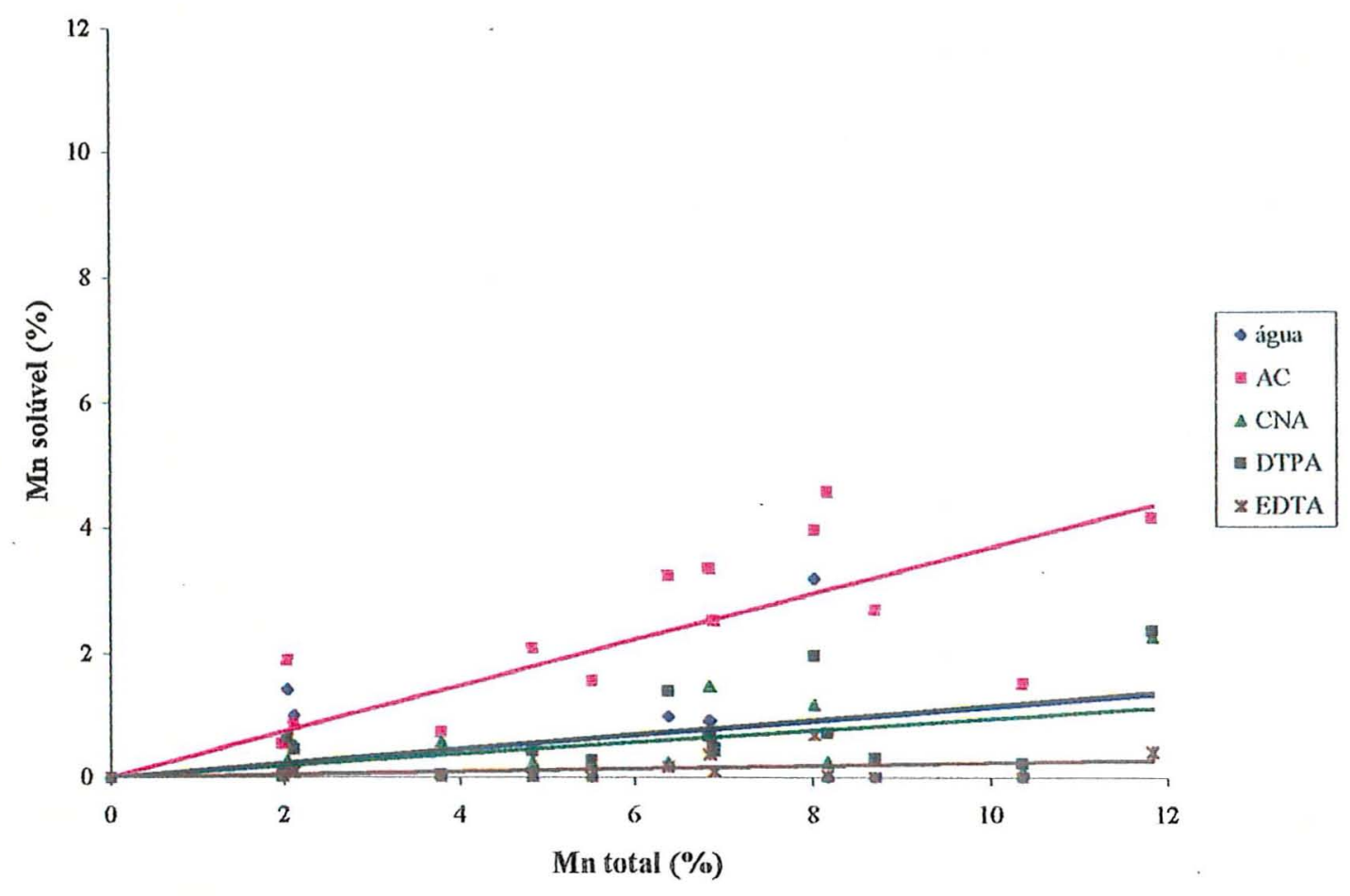

Figura 9 - Correlações apresentadas entre o teor total de manganês e os teores solubilizados pelos diferentes extratores, para os fertilizantes considerados insolúveis.

\subsubsection{Cobre}

Os teores totais de cobre determinados, assim como os teores solubilizados pelos extratores utilizados neste trabalho, tanto nos fertilizantes cujos produtores garantiam um teor mínimo do elemento, como nos fertilizantes sem cobre garantido, são apresentados na Tabela 10. É interessante observar algumas amostras sem garantia que apresentaram teor de cobre até superior a muitas com garantia. Provavelmente isso possa estar associado ao uso de resíduos metálicos no fornecimento de outros elementos, principalmente zinco. Uma evidência dessa utilização de materiais não considerados 
fertilizantes é a presença, por exemplo, de fios de cobre visiveis a olho nu nas amostras de diversos fertilizantes, conforme relatado anteriormente.

Tabela 10 - Teores de cobre (\%) extraídos pelos diferentes extratores, nos fertilizantes com e sem garantia do elemento

Extrator

\begin{tabular}{|c|c|c|c|c|c|c|c|c|c|}
\hline \multirow{3}{*}{$\mathrm{N}^{\mathrm{o}}$} & \multirow{3}{*}{ Identificação } & \multirow{3}{*}{ Tipo } & & & & & & & \\
\hline & & & garantia & $\begin{array}{l}\text { teor } \\
\text { total } \\
\end{array}$ & água & $\begin{array}{l}\text { A.C. } \\
2 \% \\
\end{array}$ & $\begin{array}{r}\text { C.N.A } \\
1+9 \\
\end{array}$ & DTPA & EDTA \\
\hline & & & \multicolumn{7}{|c|}{ (1) $\%$} \\
\hline \multicolumn{10}{|c|}{ Fertilizantes com garantia } \\
\hline 01 & FTE BR-12 & Frita & 0,8 & 0,93 & 0,01 & 0,95 & 0,80 & 0,34 & 0,12 \\
\hline 03 & FTE JCO $2 \mathrm{M}$ & Frita & 5,0 & 5,10 & 0,00 & 0,75 & 0,53 & 0,60 & 0,08 \\
\hline 04 & FTE Centro Oeste & Frita & 2,0 & 1,00 & 0,00 & 0,60 & 0,08 & 0,42 & 0,06 \\
\hline 08 & FTE Cerrrado S & Frita & 1,06 & 2,06 & 0,00 & 0,73 & 0,97 & 0,94 & 0,18 \\
\hline 10 & FTE BR - 18 & Frita & 1,6 & 2,54 & 0,00 & 0,56 & 0,88 & 0,46 & 0,38 \\
\hline 11 & FTE BR - 8 & Frita & 1,0 & 1,53 & 0,00 & 0,30 & 0,11 & 0,02 & 0,11 \\
\hline 12 & Zincoman & Frita & 7,0 & 3,79 & 0,22 & 1,18 & 0,81 & 0,53 & 0,25 \\
\hline 14 & Mib - 3 & Frita & 0,8 & 0,53 & 0,01 & 0,24 & 0,05 & 0,16 & 0,02 \\
\hline 15 & Mib - 3 & Frita & 0,8 & 0,79 & 0,00 & 0,27 & 0,13 & 0,17 & 0,06 \\
\hline 17 & Mib - 28 & Frita & 2,0 & 1,38 & 0,29 & 0,99 & 0,08 & 0,04 & 0,12 \\
\hline 18 & Agrimax-12 & Frita & 0,8 & 1,02 & 0,00 & 0,40 & 0,14 & 0,27 & 0,05 \\
\hline 21 & Agrimax CO 150 & Frita & 2,0 & 2,16 & 0,01 & 1,10 & 1,94 & 0,28 & 0,03 \\
\hline 22 & HGB 12 & Frita & 2,0 & 2,34 & 0,00 & 0,20 & 0,17 & 0,35 & 0,27 \\
\hline 27 & Nitrex MS - 2 & Sais & 1,0 & 0,91 & 0,85 & 0,77 & 0,82 & 0,82 & 0,65 \\
\hline \multicolumn{10}{|c|}{ Fertilizantes sem garantia } \\
\hline 02 & FTE S & Frita & - & 1,40 & 0,00 & 0,17 & 0,62 &, 27 & 0,12 \\
\hline 05 & Nutricitro 224 & Frita & - & 2,04 & 0,00 & 0,45 & 0,15 & 0,42 & 0,08 \\
\hline 06 & Borogran - 10 & Frita & - & 0,23 & 0,00 & 0,07 & 0,06 & 0,12 & 0,02 \\
\hline 07 & Hidrozinc Frit 20 & Frita & - & 0,00 & 0,00 & 0,00 & 0,00 & 0,00 & 0,00 \\
\hline 09 & Zincogran 20 & Frita & - & 0,52 & 0,01 & 0,08 & 0,02 & 0,02 & 0,01 \\
\hline 13 & $\mathrm{Mib}-4$ & Frita & - & 0,54 & 0,03 & 0,23 & 0,09 & 0,26 & 0,06 \\
\hline 16 & $\mathrm{Mib}-16 \mathrm{~A}$ & Frita & - & 0,31 & 0,01 & 0,03 & 0,02 & 0,30 & 0,01 \\
\hline 19 & Gran-o-zinc 20 & Frita & - & 2,71 & 0,01 & 1,43 & 0,50 & 0,54 & 0,14 \\
\hline 20 & Gran-o-bor 10 & Frita & - & 0,03 & 0,00 & 0,01 & 0,00 & 0,03 & 0,01 \\
\hline 23 & Plantzinco F IV & Frita & - & 2,16 & 0,00 & 0,29 & 0,56 & 0,22 & 0,47 \\
\hline 24 & Plantzinco F II & Frita & - & 2,10 & 0,00 & 0,80 & 0,14 & 0,26 & 0,09 \\
\hline 25 & Ulexita & Boratos & - & 0,00 & 0,00 & 0,00 & 0,00 & 0,00 & 0,00 \\
\hline 26 & Boro Importado & Boratos & - & 0,00 & 0,00 & 0,00 & 0,00 & 0,00 & 0,00 \\
\hline 28 & Copas - 8 (café) & Sais & - & 0,01 & 0,00 & 0,00 & 0,00 & 0,00 & 0,00 \\
\hline 29 & Copas - 9 (citrus) & Sais & - & 0,01 & 0,00 & 0,00 & 0,00 & 0,00 & 0,00 \\
\hline 30 & Nutri Oxi-Zn "C" & Quelato & - & 0,01 & 0,00 & 0,00 & 0,00 & 0,03 & 0,00 \\
\hline
\end{tabular}




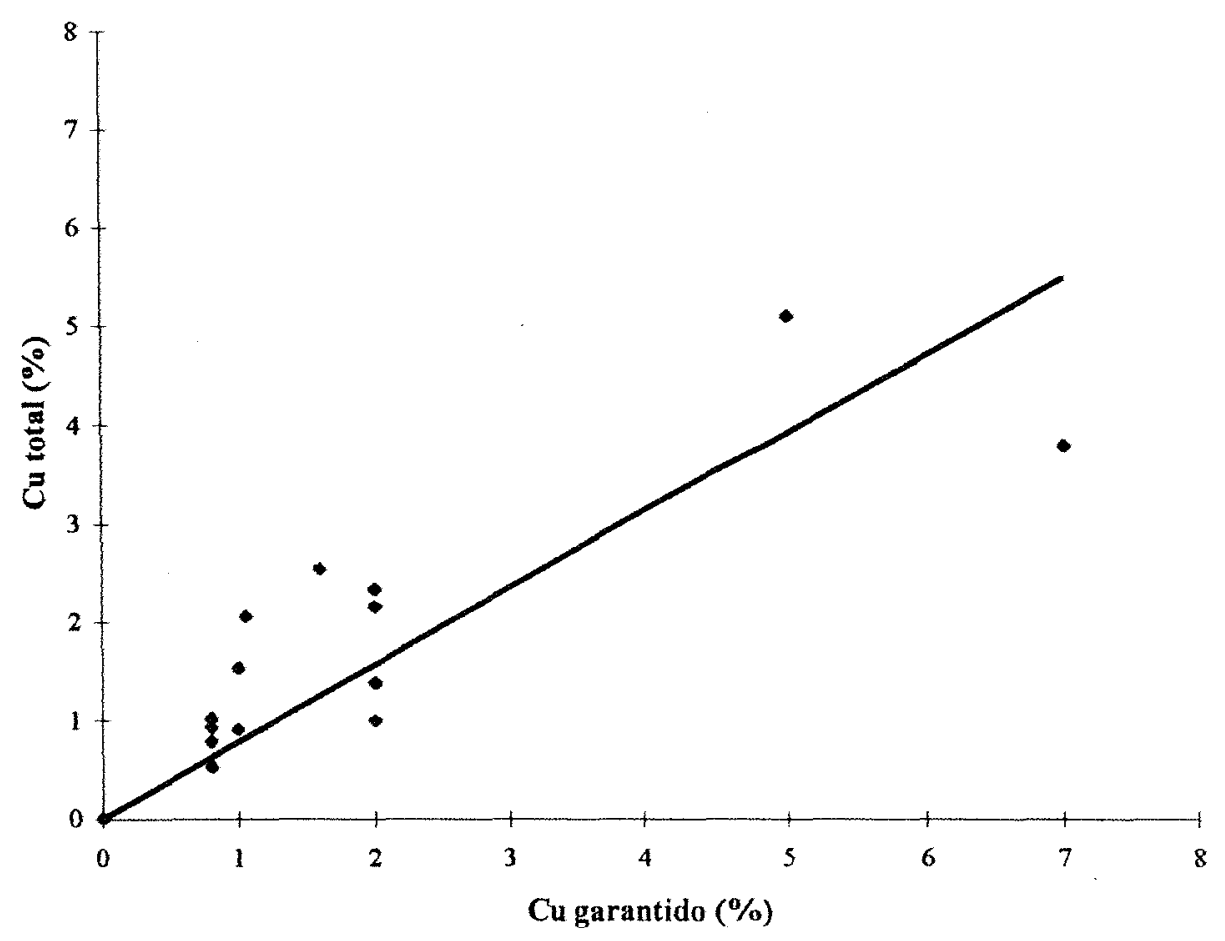

Figura 10 - Correlação apresentada entre os teores de cobre garantidos pelos fabricantes, e os teores totais extraidos com $\mathrm{HCl}$ concentrado

Para a avaliação da solubilidade de cobre presente em fertilizantes considerados solúveis foi utilizada apenas uma amostra encontrada no mercado, número 27. Pelos valores abtidos, ainda apresentados na Tabela 10, observa-se que apresentou teor total de cobre ao redor de $91 \%$ do garantido. As extrações com água, CNA e DTPA foram semelhantes, e próximas do teor total encontrado, ficando o AC um pouco abaixo. $\mathrm{O}$ EDTA foi o extrator que menos solubilizou, como também ocorreu para todos os outros micronutrientes metálicos testados, praticamente desqualificando, novamente, este extrator, no pH e concentração utilizados. Esses dados dão uma visão geral de que foram adicionados produtos altamente solúveis na fabricação do fertilizante, fato evidenciado 
pela alta solubilidade em água. Porém, seria necessário o uso de mais fontes para comprovar esses fatos.

O coeficiente de correlação entre os teores de cobre garantidos e os teores determinados de acordo com Brasil (1983), mostrou-se altamente significativo, como se observa na Figura 10. E pela Tabela 10, com algumas exceções, fica notório que o teor garantido está presente nos fertilizantes.

Na Figura 11 são apresentadas as tendências de solubilização do cobre pelos diferentes extratores, dos fertilizantes de baixa solubilidade, e com garantia do elemento.

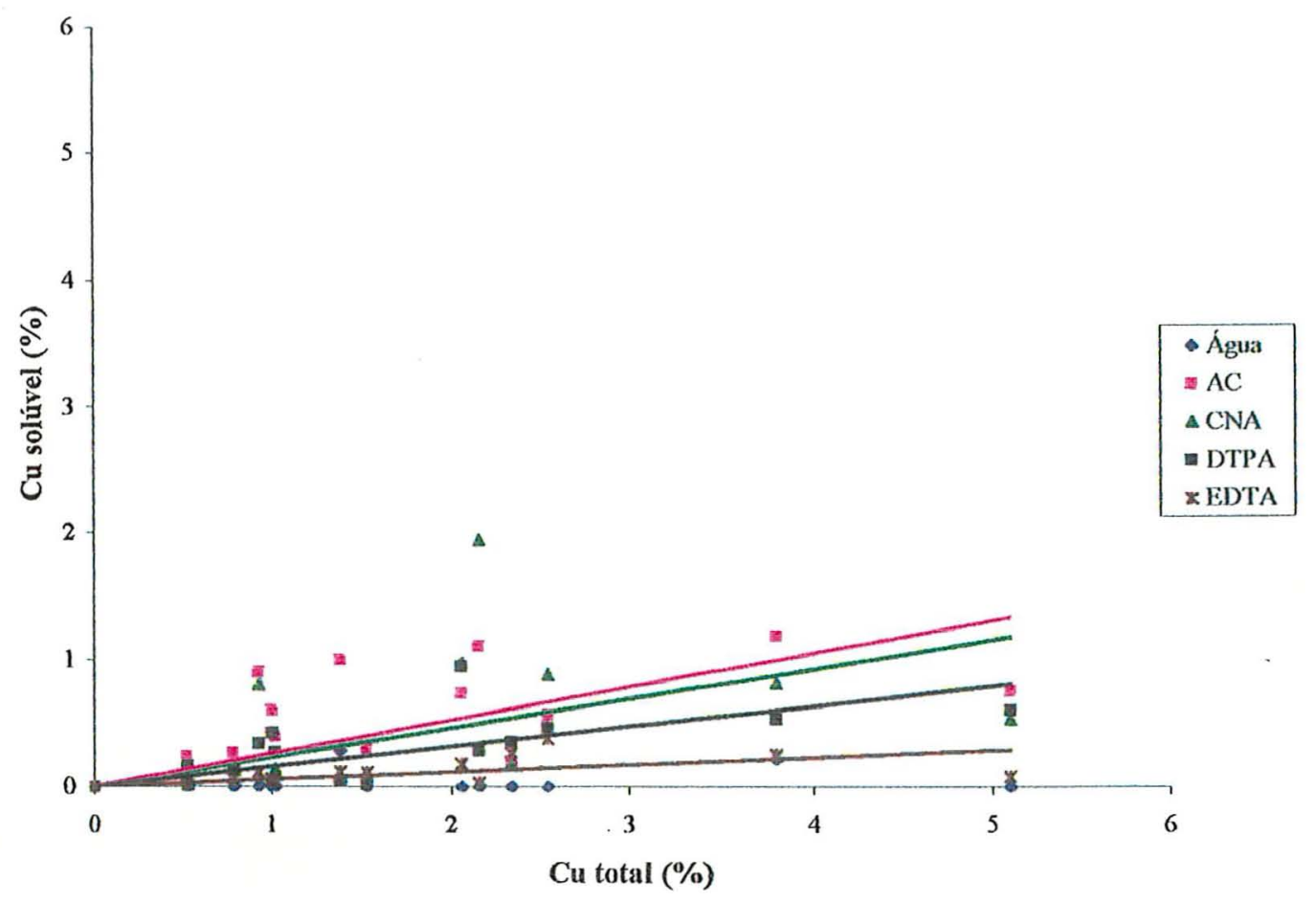

Figura 11 - Correlações apresentadas entre o teor total de cobre e os teores solubilizados pelos diferentes extratores, para os fertilizantes considerados insolúveis. 
A primeira constatação é a solubilidade praticamente zero do cobre em água, indicando a utilização de fontes bastante insolúveis na fabricação desses fertilizantes, já que, como visto anteriormente, a água possui grande capacidade de solubilizar cobre em formas solúveis presentes. Entre os outros extratores, o $\mathrm{AC}$, que foi um dos que menos extraiu o cobre da fonte solúvel, foi o que mais extraiu, seguido bem próximo pelo CNA, e mais abaixo pelo DTPA e EDTA. Os teores extraídos, porém, foram baixos, de acordo com os valores dos coeficientes angulares das retas, apresentados na Tabela 11. Esses valores são mais uma indicação da utilização de fontes não consideradas pela legislação para o fornecimento de cobre.

Tabela 11 - Valores dos coeficientes angulares da reta e dos coeficientes de correlação obtidos entre os teores garantidos pelos fabricantes e o teor total de cobre extraído por $\mathrm{HCl}$ concentrado dos fertilizantes, e entre o teor total e os teores solúveis pelos diferentes extratores, nas amostras de fertilizantes insolúveis em água.

\begin{tabular}{ccccc}
\hline \multirow{2}{*}{ Extrator } & \multicolumn{2}{c}{ Garantia x teor total } & \multicolumn{2}{c}{ Cobre total x insolúveis } \\
\cline { 2 - 5 } & $\begin{array}{c}\text { Coeficiente } \\
\text { angular da reta }\end{array}$ & $\begin{array}{c}\text { Coeficientes de } \\
\text { Correlação (r) }\end{array}$ & $\begin{array}{c}\text { Coeficiente } \\
\text { angular da reta }\end{array}$ & $\begin{array}{c}\text { Coeficientes de } \\
\text { Correlação (r) }\end{array}$ \\
\hline HCl conc & 0,79 & $0,85^{* *}$ & - & - \\
Água & - & - & 0,00 & $0,21^{\text {ns }}$ \\
A.C. 2\% & - & - & 0,26 & $0,57^{*}$ \\
C.N.A. $(1+9)$ & - & - & 0,23 & $0,44^{\text {ns }}$ \\
DTPA & - & - & 0,16 & $0,63^{* *}$ \\
EDTA & - & - & 0,05 & $0,51^{*}$ \\
\hline ns - Não significativo & & & \\
* - Significalivo ao nivel de $5 \%$ de probabilidade & & & \\
** Significativo ao nivel de 1\% de probabilidade &
\end{tabular}




\subsubsection{Micronutrientes aniônicos}

\subsubsection{Boro}

$\mathrm{Na}$ Tabela 12 encontram-se os teores de boro extraidos pelos diferentes extratores utilizados, nos fertilizantes com e sem garantia do elemento. Diferentemente dos micronutrientes metálicos, os fertilizantes sem garantia apresentaram um teor muito baixo do micronutriente

Uma primeira correlação realizada foi entre o teor de boro garantido pelos fabricantes, e o teor total extraído por $\mathrm{HCl}$ concentrado (Figura 12). Observa-se, pelo alto coeficiente de correlação encontrado, altamente significativo, e também pelo coeficiente angular da reta, relacionados na Tabela 13, que a quantidade de boro extraída é praticamente a mesma que a garantida. Pode-se concluir que para o fornecimento do elemento aos fertilizantes foram utilizadas fontes exclusivas do mesmo. Outra constatação interessante, é que para a extração oficial do boro dos fertilizantes (Brasil, 1983) utiliza-se outra metodologia. Porém, a extração utilizada nesta pesquisa mostrou-se viável, e pode acelerar o trabalho de se determinar o teor total de vários micronutrientes contidos em um mesmo fertilizante.

O boro, pela legislação, é adicionado aos fertilizantes em formas de boratos de sódio e boratos de cálcio, considerados insolúveis em água, e também como ácido bórico, solúvel.

$\mathrm{Na}$ Figura 13 observam-se as extrações de boro de todos os fertilizantes considerados solúveis. O extrator DTPA foi o que mais extraiu, fato evidenciado pelo maior coeficiente angular da reta, seguido da água e EDTA, praticamente iguais, e mais abaixo pelo $\mathrm{AC}$ e CNA. Levando-se em conta o nível de significância das correlações, e considerando que quanto mais significativas, mais coerente as extrações, isto é, aumentando o teor total, aumenta o teor extraído, observa-se que o EDTA obteve coeficiente de correlação próximo de 1,0 , e altamente significativo ao nível de $1 \%$ de probabilidade; água e EDTA tiveram significância ao nível de 5\% de probabilidade, enquanto que para $\mathrm{AC}$ e $\mathrm{CNA}$ as correlações foram não significativas. Considerando 
que, teoricamente, todo o boro nesses fertilizantes teria que estar prontamente disponivel, fica uma evidência que o extrator DTPA foi o que mais eficientemente extraiu o boro disponivel dos fertilizantes

Tabela 12 - Teores de boro (\%) extraidos pelos diferentes extratores, nos fertilizantes com e sem garantia do elemento

\section{Extrator}

\begin{tabular}{|c|c|c|c|c|c|c|c|c|c|}
\hline \multirow{3}{*}{$\mathrm{N}^{\mathrm{g}}$} & \multirow{3}{*}{ Identificação } & \multirow{3}{*}{ Tipo } & \multirow{2}{*}{ Garantia } & \multirow{3}{*}{\multicolumn{2}{|c|}{$\begin{array}{l}\text { teor } \\
\text { total água }\end{array}$}} & \multirow{3}{*}{\multicolumn{2}{|c|}{$\begin{array}{cc}\text { A.C. } & \text { C.N.A } \\
2 \% & 1+9 \\
\end{array}$}} & \multirow[b]{2}{*}{ DTPA } & \multirow[b]{2}{*}{ EDTA } \\
\hline & & & & & & & & & \\
\hline & & & \multicolumn{4}{|c|}{$\%$} & & & \\
\hline \multicolumn{10}{|c|}{ Fertilizantes com garantia } \\
\hline 01 & FTE BR-12 & Frita & 1,8 & 1,98 & 1,51 & 1,55 & 1,14 & 1,41 & 1,37 \\
\hline 02 & FTE Sementes & Frita & 2,5 & 1,05 & 0,58 & 0,95 & 1,11 & 1,08 & 1,07 \\
\hline 03 & FTE JCO $2 \mathrm{M}$ & Frita & 2,0 & 1,92 & 0,52 & 1,40 & 1,63 & 1,79 & 2,01 \\
\hline 04 & FTE Centro Oeste & Frita & 2,0 & 3,00 & 0,60 & 1,92 & 1,06 & 1,40 & 1,52 \\
\hline 05 & Nutricitro 224 & Frita & 2,0 & 2,20 & 0,64 & 1,10 & 1,55 & 2,17 & 1,03 \\
\hline 06 & Borogran - 10 & Frita & 10,0 & 9,36 & 2,93 & 4,11 & 4,37 & 9,29 & 4,00 \\
\hline 08 & FTE Cerrrado S & Frita & 0,5 & 0,64 & 0,20 & 0,42 & 0,42 & 0,39 & 1,63 \\
\hline 10 & FTE BR - 18 & Frita & 3,6 & 3,03 & 0,28 & 1,11 & 1,59 & 2,82 & 1,63 \\
\hline 11 & FTE BR - 8 & Frita & 2,5 & 2,18 & 0,80 & 0,57 & 1,86 & 2,05 & 1,83 \\
\hline 13 & Mib - 4 & Frita & 4,0 & 3,10 & 1,50 & 1,66 & 0,91 & 2,23 & 0,95 \\
\hline 14 & Mib - 3 & Frita & 1,8 & 1,44 & 1,39 & 0,65 & 1,14 & 1,28 & 1,40 \\
\hline 15 & Mib - 3 & Frita & 1,8 & 1,68 & 0,79 & 0,76 & 0,80 & 0,72 & 0,93 \\
\hline 16 & $\mathrm{Mib}-16 \mathrm{~A}$ & Frita & 2,5 & 3,02 & 0,80 & 0,61 & 2,11 & 2,79 & 0,70 \\
\hline 17 & Mib - 28 & Frita & 2,0 & 2,13 & 1,43 & 0,95 & 1,02 & 2,10 & 0,80 \\
\hline 18 & Agrimax-12 & Frita & 1,8 & 1,70 & 0,44 & 0,57 & 1,44 & 1,22 & 1,06 \\
\hline 20 & Gran-o-bor 10 & Frita & 10,0 & 9,35 & 4,88 & 2,11 & 6,70 & 9,30 & 6,17 \\
\hline 21 & Agrimax CO 150 & Frita & 2,0 & 2,10 & 0,91 & 1,47 & 1,72 & 1,74 & 0,52 \\
\hline 22 & HGB 12 & Frita & 2,0 & 1,84 & 0,62 & 0,61 & 0,72 & 1,03 & 1,82 \\
\hline 25 & Ulexita & Boratos & 12,0 & 14,49 & 3,97 & 9,60 & 10,61 & 14,40 & 9,50 \\
\hline 26 & Boro Importado & Boratos & 15,0 & 15,10 & 2,52 & 8,72 & 7,56 & 8,54 & 0,87 \\
\hline 27 & Nitrex MS - 2 & Sais & 1,5 & 1,52 & 0,71 & 0,96 & 0,90 & 1,50 & 0,77 \\
\hline 28 & Copas - 8 (café) & Sais & 3,0 & 2,87 & 2,31 & 1,57 & 2,42 & 2,68 & 2,05 \\
\hline 29 & Copas - 9 (citrus) & Sais & 2,0 & 2,10 & 1,81 & 2,10 & 0,95 & 1,83 & 2,00 \\
\hline \multicolumn{10}{|c|}{ Fertilizantes sem garantia } \\
\hline 07 & Hidrozinc Frit 20 & Frita & - & 0,05 & 0,01 & 0,01 & 0,01 & 0,01 & 0,01 \\
\hline 09 & Zincogran 20 & Frita & - & 0,14 & 0,02 & 0,02 & 0,07 & 0,01 & 0,01 \\
\hline 12 & Zincoman & Frita & - & 0,23 & 0,01 & 0,25 & 0,27 & 0,20 & 0,25 \\
\hline 19 & Gran-o-zinc 20 & Frita & - & 0,07 & 0,01 & 0,00 & 0,03 & 0,02 & 0,01 \\
\hline 23 & Plantzinco F IV & Frita & - & 0,02 & 0,01 & 0,02 & 0,01 & 0,01 & 0,01 \\
\hline 24 & Plantzinco F II & Frita & - & 0,06 & 0,01 & 0,03 & 0,03 & 0,03 & 0,03 \\
\hline 30 & Nutri Oxi-Zn "C" & Quelato & - & 0,00 & 0,00 & 0,00 & 0,00 & 0,00 & 0,00 \\
\hline
\end{tabular}




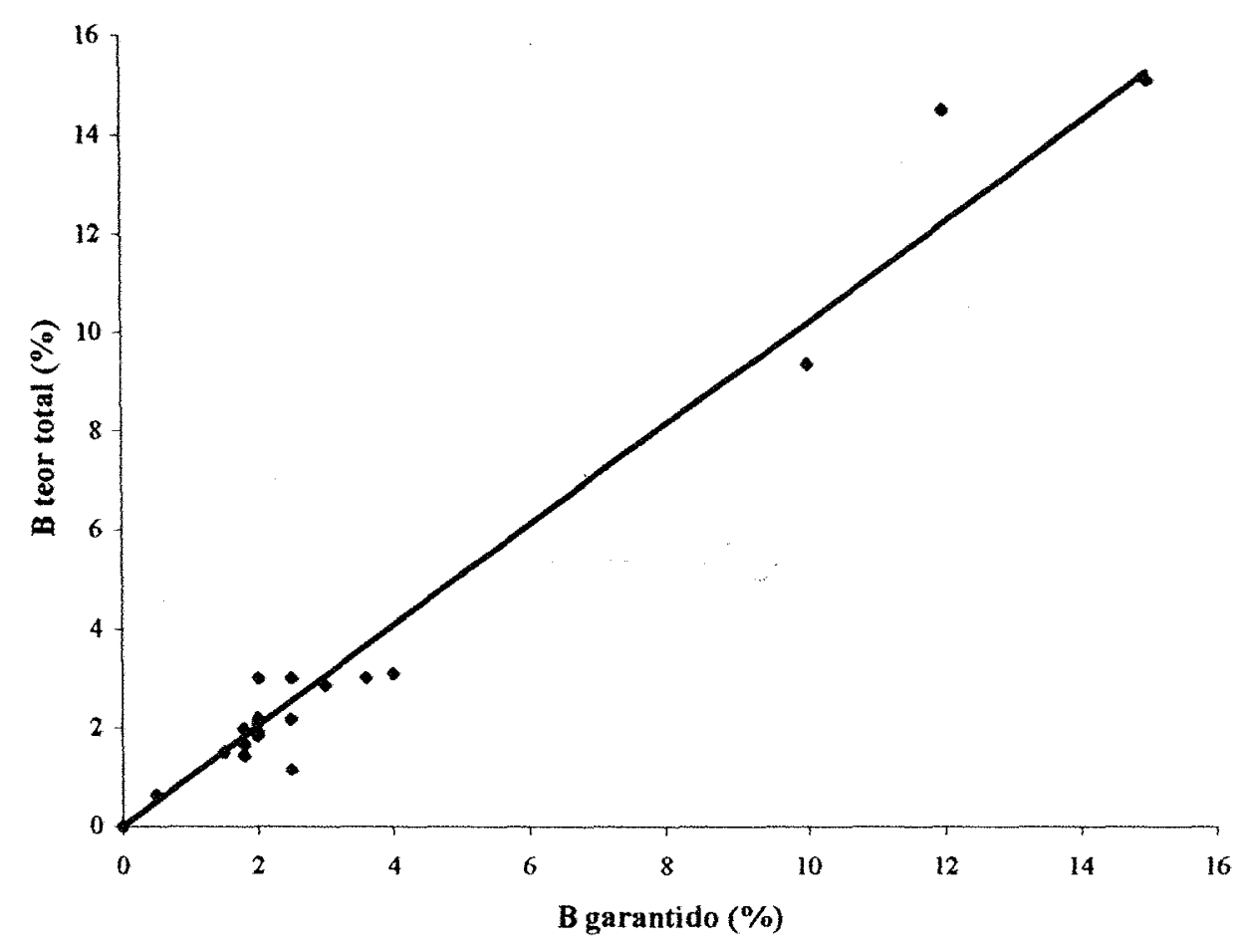

Figura 12 - Correlação apresentada entre os teores de boro garantidos pelos fabricantes, e os teores totais extraidos com $\mathrm{HCl}$ concentrado

Analisando, agora, o comportamento dos extratores para as fontes insolúveis em água, observa-se, pela Figura 14, que DTPA foi o extrator que mais extraiu, evidenciado peio alto coeficiente angular da reta (Tabela 13). Em seguida se posicionaram, pela ordem, o CNA, AC, EDTA e água. A menor extração desse último 
extrator é lógica, pela própria característica dos fertilizantes. Os altos e significativos coeficientes de correlação apresentados por todos extratores mostra que todos estão extraindo coerentemente o boro solúvel de todas amostras, isto é, estão extraindo somente formas químicas semelhantes presentes nos diferentes fertilizantes. Isto provavelmente está indicando que foram usadas fontes com boro solúvel na fabricação desses produtos.

Tabela 13 - Valores dos coeficientes angulares da reta e dos coeficientes de correlação obtidos entre os teores garantidos pelos fabricantes e o teor total de boro extraído por $\mathrm{HCl}$ concentrado dos fertilizantes, e entre o teor total e os teores solúveis pelos diferentes extratores, nas amostras de fertilizantes solúveis, e nas amostras de fertilizantes insolúveis em água.

\begin{tabular}{ccccccc}
\hline \multirow{2}{*}{ Extrator } & \multicolumn{2}{c}{ Garantia x teor total } & \multicolumn{2}{c}{ Boro total x solúveis } & \multicolumn{2}{c}{ Boro total x insolúveis } \\
\cline { 2 - 7 } & $\begin{array}{c}\text { Coeficiente } \\
\text { angular da } \\
\text { reta }\end{array}$ & $\begin{array}{c}\text { Coeficientes } \\
\text { Correlação } \\
\text { (r) }\end{array}$ & $\begin{array}{c}\text { Coeficiente } \\
\text { angular da } \\
\text { reta }\end{array}$ & $\begin{array}{c}\text { Coeficientes } \\
\text { Correlação } \\
\text { (r) }\end{array}$ & $\begin{array}{c}\text { Coeficiente } \\
\text { angular da } \\
\text { reta }\end{array}$ & $\begin{array}{c}\text { Coeficientes } \\
\text { Correlação } \\
(\mathbf{r})\end{array}$ \\
\hline HCl conc. & 1,02 & $0,99^{* *}$ & - & - & - & - \\
Água & - & - & 0,76 & $0,96^{*}$ & 0,29 & $0,82^{* *}$ \\
A.C. $2 \%$ & - & - & 0,69 & $0,87^{\text {ns }}$ & 0,53 & $0,93^{* *}$ \\
C.N.A. $(1+9)$ & - & - & 0,69 & $0,92^{\text {ms }}$ & 0,61 & $0,96^{* *}$ \\
DTPA & - & - & 0,92 & $0,99^{* *}$ & 0,83 & $0,95^{* *}$ \\
EDTA & - & - & 0,75 & $0,94^{*}$ & 0,42 & $0,69^{* *}$ \\
\hline
\end{tabular}

ns - Não significativo

* - Significativo ao nivel de $5 \%$ de probabilidade

** - Significativo ao nivel de $1 \%$ de probabilidade 


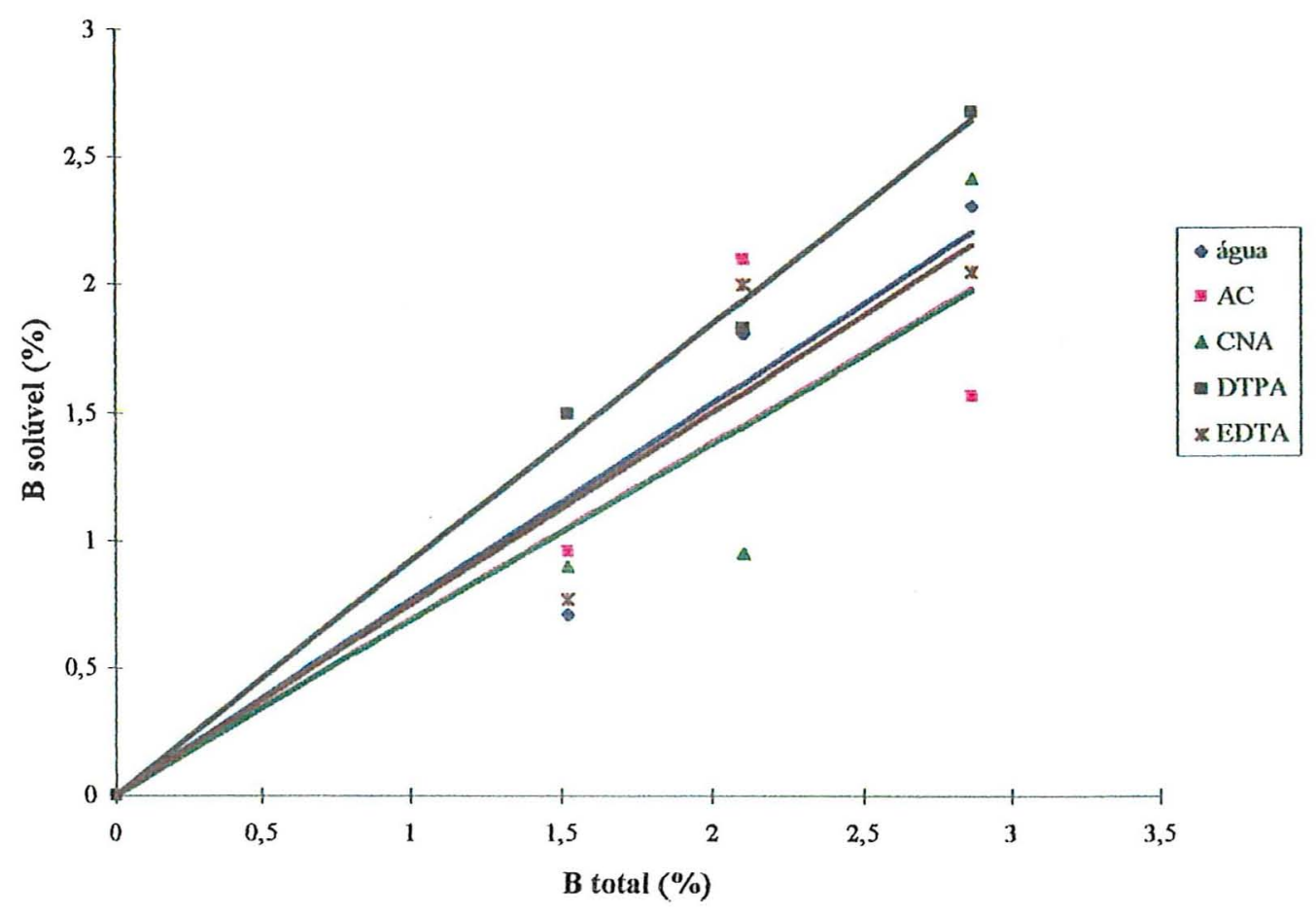

Figura 13 - Correlações apresentadas entre o teor total de boro e os teores solubilizados pelos diferentes extratores, para os fertilizantes considerados solúveis.

Levando-se em conta os dados da Tabela 13, e Figuras 13 e 14, em conjunto, pode-se chegar a uma conclusão que o DTPA foi o extrator que melhor caracterizou a disponibilidade de boro nos fertilizantes, e que a garantia pelo teor total pode estar indicando o boro realmente disponivel. 


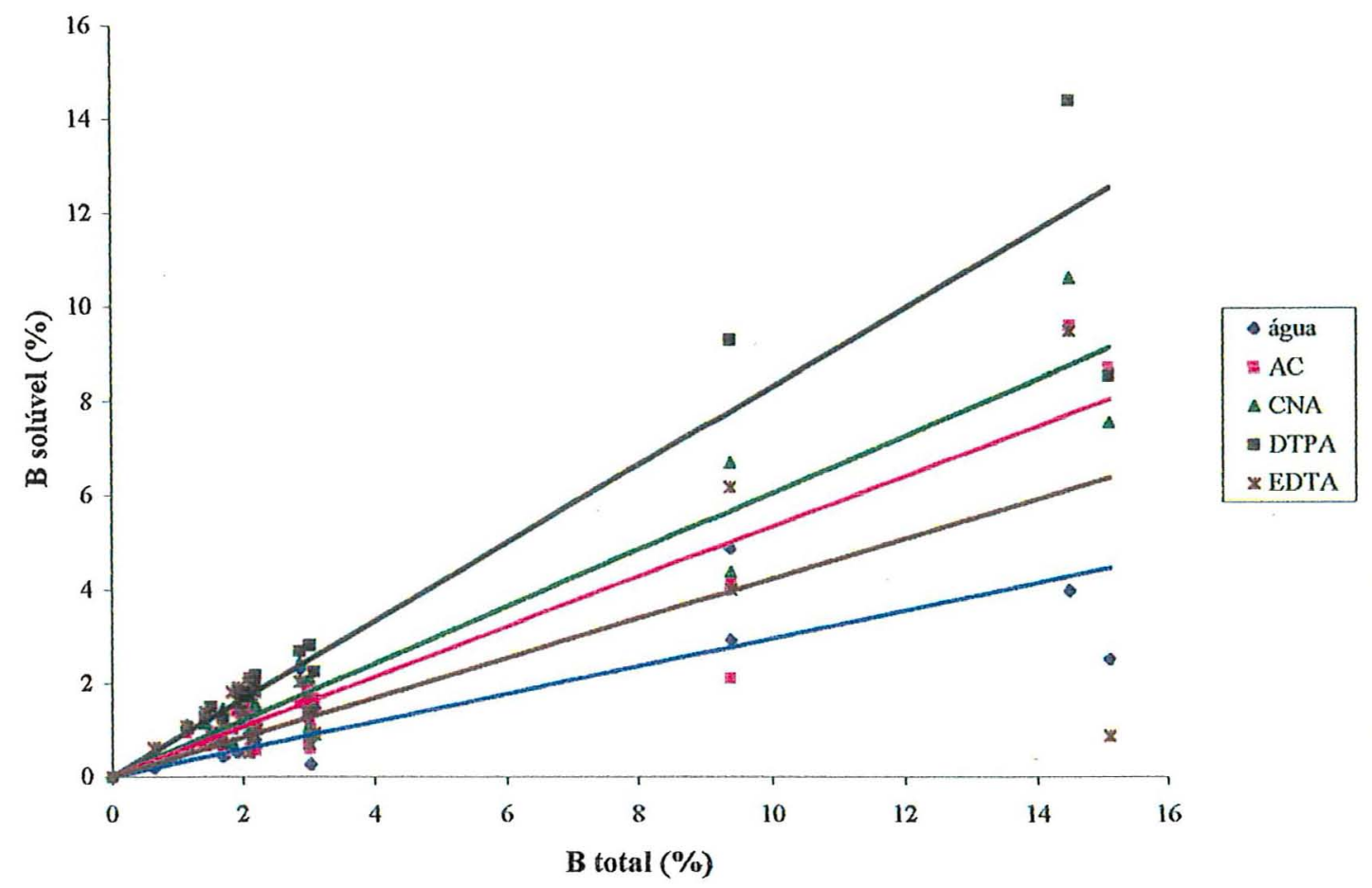

Figura 14 - Correlações apresentadas entre o teor total de boro e os teores solubilizados pelos diferentes extratores, para os fertilizantes considerados insolúveis.

\subsubsection{Molibdênio}

$\mathrm{O}$ molibdênio é um micronutriente que, devido a pequena quantidade que as plantas necessitam, é adicionado em teores totais muito baixos aos fertilizantes, conforme se observa na Tabela 14. Com exceção das amostras número 2 e 16, que garantem, respectivamente, 6 e 1,3\% do elemento, os outros fertilizantes garantem de 0,01 a $0,2 \%$, teores muito baixos que, com pequena variações, refletem em diferenças percentuais muito grandes de molibdênio. Somente por essa constatação, já se prevê uma dificuldade muito grande na avaliação da disponibilidade do elemento nos fertilizantes. 
Tabela 14 - Teores de molibdênio (\%) extraidos pelos diferentes extratores, nos fertilizantes com e sem garantia do elemento.

\begin{tabular}{|c|c|c|c|c|c|c|c|c|c|}
\hline \multirow{3}{*}{$N^{\mathbf{o}}$} & \multirow{3}{*}{ Identificação } & \multirow{3}{*}{ Tipo } & \multicolumn{7}{|c|}{ Extrator } \\
\hline & & & garantia & $\begin{array}{l}\text { teor } \\
\text { total } \\
\end{array}$ & água & $\begin{array}{l}\text { A.C. } \\
2 \% \\
\end{array}$ & $\begin{array}{r}\text { C.N.A } \\
1+9 \\
\end{array}$ & DTPA & EDTA \\
\hline & & & \multicolumn{7}{|c|}{ - $\%$} \\
\hline \multicolumn{10}{|c|}{ Fertilizantes com garantia } \\
\hline 01 & FTE BR-12 & Frita & 0,1 & 0,15 & 0,00 & 0,05 & 0,08 & 0,02 & 0,07 \\
\hline 02 & FTE Sementes & Frita & 6,0 & 4,18 & 0,13 & 3,79 & 3,92 & 2,02 & 2,29 \\
\hline 08 & FTE Cerrrado $\mathrm{S}$ & Frita & 0,01 & 0,05 & 0,01 & 0,00 & 0,01 & 0,04 & 0,04 \\
\hline 10 & FTE BR - 18 & Frita & 0,2 & 0,03 & 0,01 & 0,00 & 0,00 & 0,00 & 0,00 \\
\hline 11 & FTE BR - 8 & Frita & 0,1 & 0,06 & 0,06 & 0,05 & 0,05 & 0,05 & 0,05 \\
\hline 14 & Mib - 3 & Frita & 0,1 & 0,12 & 0,09 & 0,06 & 0,02 & 0,04 & 0,06 \\
\hline 15 & $\mathrm{Mib}-3$ & Frita & 0,1 & 0,12 & 0,11 & 0,05 & 0,04 & 0,03 & 0,10 \\
\hline 16 & Mib - 16A & Frita & 1,3 & 1,57 & 0,38 & 0,76 & 0,14 & 1,41 & 1,14 \\
\hline 18 & Agrimax-12 & Frita & 0,1 & 0,11 & 0,05 & 0,10 & 0,01 & 0,03 & 0,06 \\
\hline \multicolumn{10}{|c|}{ Fertilizantes sem garantia } \\
\hline 03 & FTE JCO 2M & Frita & - & 0,00 & 0,00 & 0,00 & 0,00 & 0,00 & 0,00 \\
\hline 04 & FTE Centro Oeste & Frita & - & 0,00 & 0,00 & 0,00 & 0,00 & 0,00 & 0,00 \\
\hline 05 & Nutricitro 224 & Frita & - & 0,00 & 0,00 & 0,00 & 0,00 & 0,00 & 0,00 \\
\hline 06 & Borogran - 10 & Frita & - & 0,00 & 0,00 & 0,00 & 0,00 & 0,00 & 0,00 \\
\hline 07 & Hidrozinc Frit 20 & Frita & - & 0,00 & 0,00 & 0,00 & 0,00 & 0,00 & 0,00 \\
\hline 09 & Zincogran 20 & Frita & - & 0,00 & 0,00 & 0,00 & 0,00 & 0,00 & 0,00 \\
\hline 12 & Zincoman & Frita & - & 0,00 & 0,00 & 0,00 & 0,00 & 0,00 & 0,00 \\
\hline 13 & Mib - 4 & Frita & - & 0,00 & 0,00 & 0,00 & 0,00 & 0,00 & 0,00 \\
\hline 17 & Mib - 28 & Frita & - & 0,00 & 0,00 & 0,00 & 0,00 & 0,00 & 0,00 \\
\hline 19 & Gran-o-zinc 20 & Frita & - & 0,00 & 0,00 & 0,00 & 0,00 & 0,00 & 0,00 \\
\hline 20 & Gran-o-bor 10 & Frita & - & 0,00 & 0,00 & 0,00 & 0,00 & 0,00 & 0,00 \\
\hline 21 & Agrimax CO 150 & Frita & - & 0,00 & 0,00 & 0,00 & 0,00 & 0,00 & 0,00 \\
\hline 22 & HGB 12 & Frita & - & 0,00 & 0,00 & 0,00 & 0,00 & 0,00 & 0,00 \\
\hline 23 & Plantzinco F IV & Frita & - & 0,00 & 0,00 & 0,00 & 0,00 & 0,00 & 0,00 \\
\hline 24 & Plantzinco F II & Frita & - & 0,00 & 0,00 & 0,00 & 0,00 & 0,00 & 0,00 \\
\hline 25 & Ulexita & Boratos & - & 0,00 & 0,00 & 0,00 & 0,00 & 0,00 & 0,00 \\
\hline 26 & Boro Importado & Boratos & - & 0,00 & 0,00 & 0,00 & 0,00 & 0,00 & 0,00 \\
\hline 27 & Nitrex MS - 2 & Sais & - & 0,00 & 0,00 & 0,00 & 0,00 & 0,00 & 0,00 \\
\hline 28 & Copas - 8 (café) & Sais & - & 0,00 & 0,00 & 0,00 & 0,00 & 0,00 & 0,00 \\
\hline 29 & Copas - 9 (citrus) & Sais & - & 0,00 & 0,00 & 0,00 & 0,00 & 0,00 & 0,00 \\
\hline 30 & Nutri Oxi-Zn "C" & Quelato & - & 0,00 & 0,00 & 0,00 & 0,00 & 0,00 & 0,00 \\
\hline
\end{tabular}

Uma primeira observação, também pela Tabela 14 , é que em todos os fertilizantes sem garantia do elemento, não se detectou nenhum teor do elemento. Quanto as amostras com garantia, observou-se que, com exceção das amostras 2 e 10, todas as outras apresentaram teor próximo ou superior ao garantido, demonstrando que 0 
molibdênio, no geral, foi adicionado ao fertilizante, fato que pode ser comprovado pelo alto e significante coeficiente de correlação entre os teores garantidos e os teores totais determinados, apresentados na Figura 15. A amostra 2, que garante alto teor de molibdênio, é recomendada para mistura com sementes, pré-plantio, de espécies leguminosas. $\mathrm{O}$ menor teor do elemento encontrado pode ser comprometedor para as culturas.

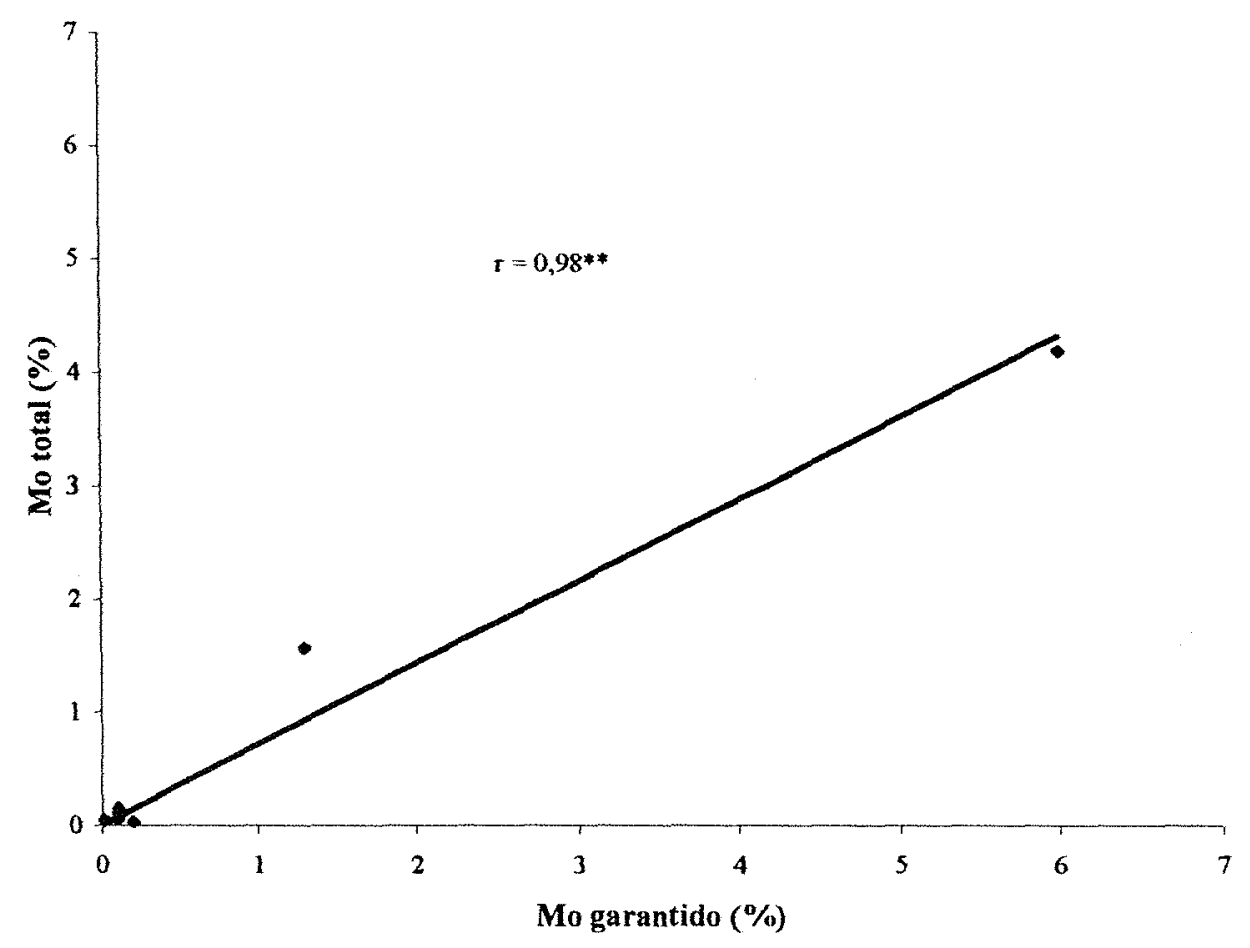

Figura 15 - Correlação apresentada entre os teores de molibdênio garantidos pelos fabricantes, e os teores totais extraídos com $\mathrm{HCl}$ concentrado

A caracterização da solubilidade do molibdênio pelos diferentes extratores é apresentada na Figura 16, para todos os fertilizantes, e Figura 17, para os fertilizantes com baixo teor. Somente pelas figuras, observa-se uma grande incoerência de resultados. Em cada caso ocorreu uma tendência diferenciada de extração por parte dos extratores. Isso ocorreu devido à grande diferença de teores apresentadas pelos 
fertilizantes; a presença de mais fertilizantes em doses intermediárias favoreceria um melhor estudo. Também os estudos com produtos com doses muito baixas compromete a exatidão dos dados, como já citado anteriormente.

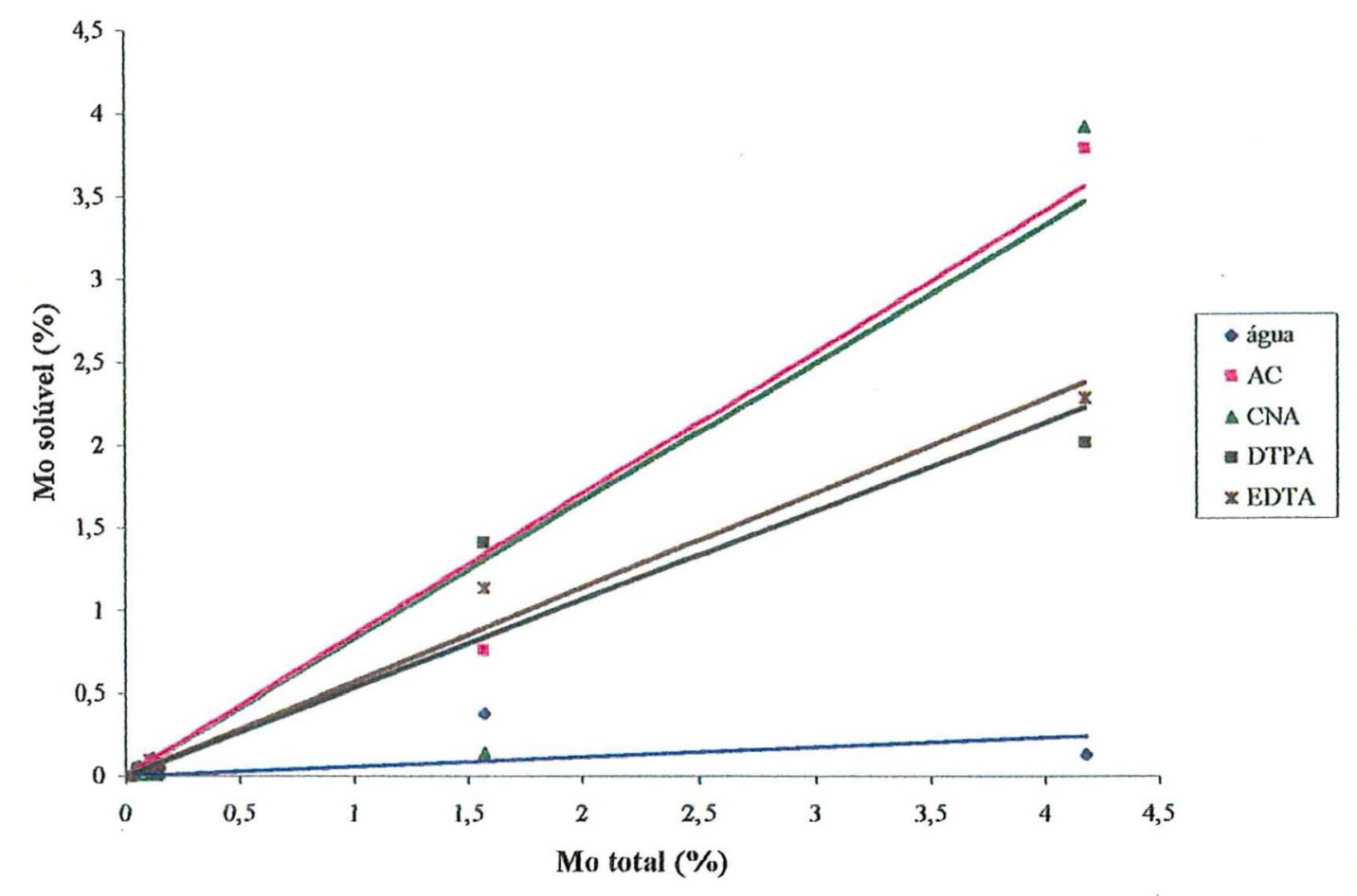

Figura 16 - Correlações apresentadas entre o teor total de molibdênio e os teores solubilizados pelos diferentes extratores, para todos os fertilizantes com garantia do elemento.

A boa solubilidade em água da maioria dos produtos com baixo teor de molibdênio (Tabela 14) leva a indicação de que o micronutriente foi fornecido em formas solúveis a esses fertilizantes. As amostras com teor elevado apresentaram baixa solubilidade em água, o que indica produtos mais insolúveis em sua composição. 


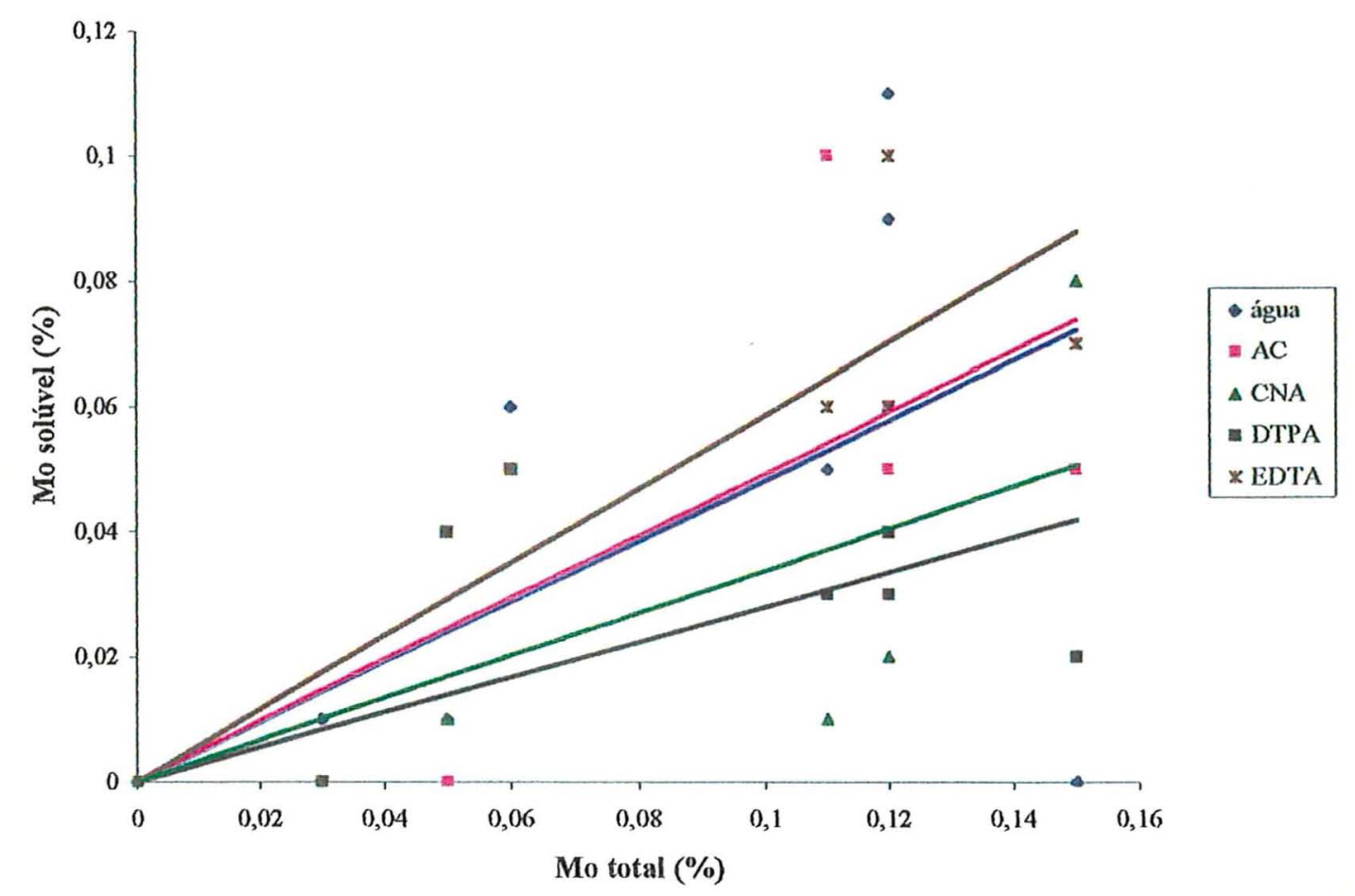

Figura 17 - Correlações apresentadas entre o teor total de molibdênio e os teores solubilizados pelos diferentes extratores, para os fertilizantes com baixo teor garantido

\subsection{Disponibilidade dos micronutrientes para as plantas pelo método de Neubauer \& Schneider}

$\mathrm{Na}$ Tabela 15 encontram-se as quantidades de matéria seca, em gramas, produzida por cada uma das três repetições do teste de Neubauer \& Schneider, para cada fertilizante. É interessante observar que a quantidade produzida foi muito pequena, não sendo possível determinar todos os micronutrientes em cada repetição. Foi feita, então, a mistura das três repetições para cada fertilizante, determinando-se os teores de boro, 
cobre, ferro, manganês e zinco absorvidos pelas plantas de arroz. O molibdênio não foi determinado, pois para sua análise são necessários 5,0 g de matéria seca (Malavolta et al., 1989).

Tabela 15 - Quantidades de matéria seca, em gramas, produzida por cada uma das três repetições (A, B, C) no teste de Neubauer \& Schneider, para cada fertilizante, e para o tratamento testemunha.

\begin{tabular}{|c|c|c|c|c|c|}
\hline \multirow{3}{*}{$\mathrm{N}^{\mathbf{o}}$} & \multicolumn{5}{|c|}{ Repetições } \\
\hline & \multirow[t]{2}{*}{ Identificação } & $\mathrm{A}$ & B & $\mathrm{C}$ & Média \\
\hline & & \multicolumn{4}{|c|}{ - } \\
\hline & Testemunha & 0,22 & 0,29 & 0,21 & 0,24 \\
\hline 01 & FTE BR-12 & 0,35 & 0,36 & 0,33 & 0,35 \\
\hline 02 & FTE Sementes & 0,25 & 0,25 & 0,26 & 0,25 \\
\hline 03 & FTE JCO 2M & 0,37 & 0,34 & 0,31 & 0,34 \\
\hline 04 & FTE Centro Oeste & 0,29 & 0,27 & 0,27 & 0,27 \\
\hline 05 & Nutricitro 224 & 0,31 & 0,28 & 0,30 & 0,30 \\
\hline 06 & Borogran - 10 & 0,38 & 0,37 & 0,30 & 0,35 \\
\hline 07 & Hidrozinc Frit 20 & 0,31 & 0,28 & 0,28 & 0,29 \\
\hline 08 & FTE Cerrrado S & 0,30 & 0,35 & 0,30 & 0,32 \\
\hline 09 & Zincogran 20 & 0,22 & 0,32 & 0,24 & 0,26 \\
\hline 10 & FTE BR - 18 & 0,29 & 0,28 & 0,30 & 0,29 \\
\hline 11 & FTE BR - 8 & 0,28 & 0,28 & 0,28 & 0,28 \\
\hline 12 & Zincoman & 0,31 & 0,28 & 0,30 & 0,30 \\
\hline 13 & Mib - 4 & 0,39 & 0,35 & 0,30 & 0,35 \\
\hline 14 & Mib - 3 & 0,35 & 0,35 & 0,35 & 0,35 \\
\hline 15 & $\mathrm{Mib}-3$ & 0,25 & 0,25 & 0,28 & 0,26 \\
\hline 16 & Mib $-16 A$ & 0,32 & 0,32 & 0,33 & 0,32 \\
\hline 17 & Mib - 28 & 0,34 & 0,39 & 0,30 & 0,35 \\
\hline 18 & Agrimax-12 & 0,24 & 0,24 & 0,26 & 0,25 \\
\hline 19 & Gran-o-zinc 20 & 0,42 & 0,35 & 0,35 & 0,37 \\
\hline 20 & Gran-o-bor 10 & 0,35 & 0,36 & 0,36 & 0,36 \\
\hline 21 & Agrimax CO 150 & 0,30 & 0,36 & 0,34 & 0,33 \\
\hline 22 & HGB 12 & 0,30 & 0,30 & 0,31 & 0,30 \\
\hline 23 & Plantzinco F IV & 0,29 & 0,31 & 0,30 & 0,30 \\
\hline 24 & Plantzinco F II & 0,30 & 0,30 & 0,26 & 0,28 \\
\hline 25 & Ulexita & 0,35 & 0,36 & 0,33 & 0,35 \\
\hline 26 & Boro Importado & 0,30 & 0,36 & 0,34 & 0,33 \\
\hline 27 & Nitrex MS - 2 & 0,35 & 0,36 & 0,36 & 0,36 \\
\hline 28 & Copas - 8 (café) & 0,36 & 0,36 & 0,32 & 0,35 \\
\hline 29 & Copas - 9 (citrus) & 0,40 & 0,30 & 0,33 & 0,34 \\
\hline 30 & Nutri Oxi-Zn "C" & 0,31 & 0,31 & 0,33 & 0,32 \\
\hline
\end{tabular}


Os teores de boro, cobre, ferro, manganês e zinco, em $\mathrm{mg} \mathrm{kg}^{-1}$, absorvidos pelas plantas de arroz são mostrados na Tabela 16; somente foram analisados para cada tratamento os micronutrientes garantidos pelo fertilizante utilizado. Multiplicando-se o

Tabela 16 - Teores de boro, cobre, ferro, manganês e zinco, em $\mathrm{mg} \mathrm{kg}^{-1}$, absorvidos pelas plantas de arroz.

\begin{tabular}{|c|c|c|c|c|c|c|}
\hline \multirow{2}{*}{$N^{0}$} & \multirow{2}{*}{ Identificação } & B & $\mathrm{Cu}$ & $\mathrm{Fe}$ & $\mathrm{Mn}$ & $\mathrm{Zn}$ \\
\hline & & \multicolumn{5}{|c|}{$\mathrm{mg} \mathrm{kg}^{-1}$} \\
\hline & Testemunha & 23,1 & 3,3 & 64,0 & 24,5 & 30,0 \\
\hline 01 & FTE BR-12 & 50,1 & 5,8 & 60,9 & 43,8 & 73,4 \\
\hline 02 & FTE Sementes & 60,6 & 5,1 & 58,1 & 34,1 & 137,2 \\
\hline 03 & FTE JCO $2 \mathrm{M}$ & 54,7 & 9,3 & 79,9 & 53,1 & 79,6 \\
\hline 04 & FTE Centro Oeste & 105,1 & 6,4 & - & 37,0 & 140,9 \\
\hline 05 & Nutricitro 224 & 47,9 & - & - & 42,0 & 398,6 \\
\hline 06 & Borogran - 10 & 111,0 & - & - & - & - \\
\hline 07 & Hidrozinc Frit 20 & - & - & - & - & 420,3 \\
\hline 08 & FTE Cerrrado S & 22,8 & 10,2 & - & 52,0 & 277,2 \\
\hline 09 & Zincogran 20 & - & - & - & - & 415,9 \\
\hline 10 & FTE BR - 18 & 56,8 & 12,9 & - & - & 451,6 \\
\hline 11 & FTE BR - 8 & - & - & - & - & - \\
\hline 12 & Zincoman & - & 12,5 & - & 90,1 & 227,9 \\
\hline 13 & $\mathrm{Mib}-4$ & 69,8 & - & - & - & 211,4 \\
\hline 14 & Mib - 3 & 26,7 & 4,1 & 58,7 & 34,7 & 54,4 \\
\hline 15 & $\mathrm{Mib}-3$ & 62,0 & 6,3 & 70,2 & 40,6 & 233,7 \\
\hline 16 & Mib $-16 A$ & 35,3 & - & - & - & 353,4 \\
\hline 17 & Mib - 28 & 47,2 & 9,3 & - & 71,3 & 275,3 \\
\hline 18 & Agrimax -12 & 73,9 & 4,8 & 70,5 & 30,7 & 80,4 \\
\hline 19 & Gran-o-zinc 20 & - & - & 67,8 & - & 158,4 \\
\hline 20 & Gran-o-bor 10 & 109,7 & - & - & - & - \\
\hline 21 & Agrimax CO 150 & 33,3 & 14,1 & - & 51,8 & 116,9 \\
\hline 22 & HGB 12 & 39,2 & 10,1 & - & 75,0 & 329,1 \\
\hline 23 & Plantzinco F IV & - & - & 52,4 & - & 366,6 \\
\hline 24 & Plantzinco F II & - & - & - & - & 366,0 \\
\hline 25 & Ulexita & 109,4 & - & - & - & - \\
\hline 26 & Boro Importado & 116,0 & - & - & - & - \\
\hline 27 & Nitrex MS - 2 & 41,3 & 10,8 & - & 73,6 & 204,7 \\
\hline 28 & Copas - 8 (café) & 24,0 & - & - & - & 250,5 \\
\hline 29 & Copas - 9 (citrus) & 27,9 & - & - & 209,2 & 370,8 \\
\hline 30 & Nutri Oxi-Zn "C" & - & - & - & - & 335,0 \\
\hline
\end{tabular}


valor da média de matéria seca produzida em cada tratamento, pelo teor de cada micronutriente absorvido, tem-se o acúmulo dos micronutrientes nas plantas de arroz. $\mathrm{E}$ subtraindo-se deste valor o acumulado pelas plantas testemunha, isto é, que não receberam nenhum micronutriente via fertilizante, obtém-se a quantidade de cada micronutriente acumulado, em microgramas, oriundo dos fertilizantes. Nas Tabelas 17 a 21 , observam-se, respectivamente, as quantidades de boro, cobre, ferro, manganês e zinco acumuladas pelas plantas de arroz, após a realização do teste de Neubauer \& Schneider, assim como as quantidades de cada micronutriente fornecido pelos fertilizantes, baseando-se no teor total e nos teores solúveis pelos diferentes extratores.

Tabela 17 - Quantidade de boro fornecido pelos fertilizantes com garantia, baseando-se no teor total e nos teores solúveis pelos diferentes extratores, e acumulado pelas plantas de arroz.

\begin{tabular}{|c|c|c|c|c|c|c|c|c|}
\hline \multirow{3}{*}{$\mathbf{N}^{0}$} & \multirow{3}{*}{ Identificação } & \multicolumn{6}{|c|}{ Fomecido pelos fertilizantes } & \multirow{2}{*}{$\begin{array}{c}\text { Acumulado } \\
\text { pelas } \\
\text { plantas } \\
\end{array}$} \\
\hline & & $\begin{array}{l}\text { Teor } \\
\text { total }\end{array}$ & água & $\begin{array}{l}\text { A.C. } \\
2 \% \\
\end{array}$ & $\begin{array}{c}\text { C.N.A } \\
1+9\end{array}$ & DTPA & EDTA & \\
\hline & & \multicolumn{7}{|c|}{ 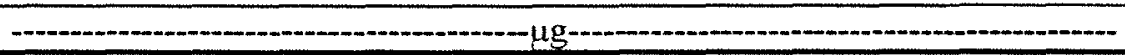 } \\
\hline 01 & FTE BR-12 & 19,8 & 15,1 & 15,5 & 11,4 & 14,1 & 13,7 & 12,1 \\
\hline 02 & FTE Sementes & 10,5 & 5,80 & 9,50 & 11,1 & 10,8 & 10,7 & 10,9 \\
\hline 03 & FTE JCO $2 \mathrm{M}$ & 19,2 & 5,02 & 14,0 & 16,3 & 17,9 & 20,1 & 13,6 \\
\hline 04 & FTE Centro Oeste & 30,0 & 6,00 & 19,2 & 10,6 & 14,0 & 15,2 & 20,8 \\
\hline 05 & Nutricitro 224 & 22,0 & 6,40 & 11,0 & 15,5 & 21,7 & 10,3 & 11,3 \\
\hline 06 & Borogran - 10 & 93,6 & 9,30 & 41,1 & 43,7 & 92,9 & 40,0 & 33,4 \\
\hline 08 & FTE Cerrrado S & 6,40 & 2,00 & 4,20 & 4,20 & 3,90 & 16,3 & 2,50 \\
\hline 10 & FTE BR - 18 & 30,3 & 2,80 & 11,1 & 15,9 & 28,2 & 16,3 & 14,4 \\
\hline 11 & FTE BR - 8 & 21,8 & 8,00 & 5,70 & 18,6 & 20,5 & 18,3 & 15,0 \\
\hline 13 & Mib - 4 & 31,0 & 15,0 & 16,6 & 9,10 & 22,3 & 9,50 & 18,9 \\
\hline 14 & Mib - 3 & 14,4 & 13,9 & 6,50 & 11,4 & 12,8 & 14,0 & 3,80 \\
\hline 15 & $\mathrm{Mib}-3$ & 16,8 & 7,90 & 7,60 & 8,00 & 7,20 & 9,30 & 9,70 \\
\hline 16 & $\mathrm{Mib}-16 \mathrm{~A}$ & 30,2 & 8,00 & 6,10 & 21,1 & 27,9 & 7,00 & 6,90 \\
\hline 17 & $\mathrm{Mib}-28$ & 21,3 & 14,3 & 9,50 & 10,2 & 21,0 & 8,00 & 11,0 \\
\hline 18 & Agrimax-12 & 17,0 & 4,40 & 5,70 & 14,4 & 12,2 & 10,6 & 12,9 \\
\hline 20 & Gran-o-bor 10 & 93,5 & 48,8 & 21,1 & 67,0 & 93,0 & 61,7 & 32,9 \\
\hline 21 & Agrimax CO 150 & 21,0 & 9,10 & 14,7 & 17,2 & 17,4 & 5,20 & 6,10 \\
\hline 22 & HGB 12 & 18,4 & 6,20 & 6,10 & 7,20 & 10,3 & 18,2 & 6,30 \\
\hline 25 & Ulexita & 144,9 & 39,7 & 96,0 & 106,1 & 144,0 & 95,0 & 32,8 \\
\hline 26 & Boro Importado & 151,0 & 25,2 & 87,2 & 75,6 & 85,4 & 8,70 & 35,1 \\
\hline 27 & Nitrex MS - 2 & 15,2 & 7,10 & 9,60 & 9,00 & 15,0 & 7,70 & 8,90 \\
\hline 28 & Copas - 8 (café) & 28,7 & 23,1 & 15,7 & 24,2 & 26,8 & 20,5 & 2,90 \\
\hline 29 & Copas - 9 (citrus) & 21,0 & 18,1 & 21,0 & 9,50 & 18,3 & 20,0 & 4,20 \\
\hline
\end{tabular}


Tabela 18 - Quantidade de cobre fornecido pelos fertilizantes com garantia, baseando-se no teor total e nos teores solúveis pelos diferentes extratores, e acumulado pelas plantas de arroz.

\begin{tabular}{|c|c|c|c|c|c|c|c|c|}
\hline \multirow{3}{*}{$\mathbf{N}^{0}$} & \multirow{3}{*}{ Identificação } & \multicolumn{6}{|c|}{ Fornecido pelos fertilizantes } & \multirow{2}{*}{$\begin{array}{c}\text { Acumulado } \\
\text { pelas } \\
\text { plantas } \\
\end{array}$} \\
\hline & & $\begin{array}{l}\text { Teor } \\
\text { total }\end{array}$ & água & $\begin{array}{l}\text { A.C. } \\
2 \% \\
\end{array}$ & $\begin{array}{l}\text { C.N.A } \\
1+9 \\
\end{array}$ & DTPA & EDTA & \\
\hline & & \multicolumn{7}{|c|}{ 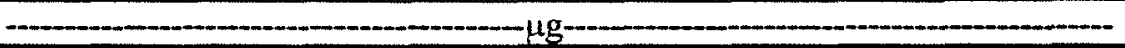 } \\
\hline 01 & FTE BR-12 & 9,30 & 0,10 & 9,50 & 8,00 & 3,40 & 1,20 & 1,30 \\
\hline 03 & FTE JCO $2 \mathrm{M}$ & 51,0 & 0,00 & 7,50 & 5,30 & 6,00 & 0,80 & 2,50 \\
\hline 04 & FTE Centro Oeste & 10,0 & 0,00 & 6,00 & 0,80 & 4,20 & 0,60 & 0,80 \\
\hline 08 & FTE Cerrrado S & 20,6 & 0,00 & 7,30 & 9,70 & 9,40 & 1,80 & 2,30 \\
\hline 10 & FTE BR - 18 & 25,4 & 0,00 & 5,60 & 8,80 & 4,60 & 3,80 & 3,80 \\
\hline 11 & FTE BR - 8 & 15,3 & 0,00 & 3,00 & 1,10 & 0,20 & 1,10 & 1,00 \\
\hline 12 & Zincoman & 37,9 & 2,20 & 11,8 & 8,10 & 5,30 & 2,50 & 3,60 \\
\hline 14 & Mib - 3 & 5,30 & 0,10 & 2,40 & 0,50 & 1,60 & 0,20 & 0,70 \\
\hline 15 & $\mathrm{Mib}-3$ & 7,90 & 0,00 & 2,70 & 1,30 & 1,70 & 0,60 & 0,90 \\
\hline 17 & Mib - 28 & 13,8 & 2,90 & 9,90 & 0,80 & 0,40 & 1,20 & 2,50 \\
\hline 18 & Agrimax-12 & 10,2 & 0,00 & 4,00 & 1,40 & 2,70 & 0,50 & 0,40 \\
\hline 21 & Agrimax CO 150 & 21,6 & 0,10 & 11,0 & 9,40 & 2,80 & 0,30 & 4,20 \\
\hline 22 & HGB 12 & 23,4 & 0,00 & 2,00 & 1,70 & 3,50 & 2,70 & 2,30 \\
\hline 27 & Nitrex MS - 2 & 9,10 & 8,50 & 7,70 & 8,20 & 8,20 & 6,50 & 3,00 \\
\hline
\end{tabular}

Tabela 19 - Quantidade de ferro fornecido pelos fertilizantes com garantia, baseando-se no teor total e nos teores solúveis pelos diferentes extratores, e acumulado pelas plantas de arroz.

\begin{tabular}{|c|c|c|c|c|c|c|c|c|}
\hline \multirow[b]{2}{*}{$\mathbf{N}^{\mathbf{a}}$} & \multirow[b]{2}{*}{ Identificação } & \multicolumn{6}{|c|}{ Fornecido pelos fertilizantes } & \multirow{2}{*}{$\begin{array}{c}\text { Acumulado } \\
\text { pelas } \\
\text { plantas } \\
\end{array}$} \\
\hline & & $\begin{array}{l}\text { teor } \\
\text { total }\end{array}$ & Água & $\begin{array}{l}\text { A.C. } \\
2 \%\end{array}$ & $\begin{array}{l}\text { C.N.A } \\
1+9\end{array}$ & DTPA & EDTA & \\
\hline 01 & FTF $\mathrm{RR}-12$ & 1016 & 000 & 050 & 330 & 160 & 030 & 320 \\
\hline 03 & FTE JCO $2 \mathrm{M}$ & 50,7 & 0,00 & 7,10 & 0,50 & 0,40 & 0,10 & 8,40 \\
\hline 11 & FTE BR -8 & 59,4 & 0,00 & 7,80 & 0,50 & 0,60 & 0,10 & 0,50 \\
\hline 14 & $\mathrm{Mib}-3$ & 25,1 & 0,10 & 7,90 & 1,30 & 0,10 & 0,20 & 5,30 \\
\hline 15 & $\mathrm{Mib}-3$ & 41,1 & 0,00 & 3,20 & 0,90 & 0,40 & 0,10 & 1,50 \\
\hline 18 & Agrimax-12 & 90,6 & 0,00 & 8,60 & 1,10 & 0,30 & 0,30 & 1,50 \\
\hline 19 & Gran-o-zinc 20 & 113,0 & 0,00 & 19,6 & 4,70 & 0,20 & 0,20 & 8,50 \\
\hline 23 & Plantzinco F IV & 8,30 & 0,00 & 2,80 & 1,00 & 0,20 & 0,10 & 0,50 \\
\hline
\end{tabular}


$\mathrm{Na}$ Tabela 22 são apresentados os coeficientes de correlação (r) obtidos entre a quantidade de boro, cobre, ferro, manganês e zinco acumulados pelas plantas de arroz, e as quantidades fornecidas pelos fertilizantes, baseando-se no teor total e nos teores solúveis nos diferentes extratores.

Tabela 20 - Quantidade de manganês fornecido pelos fertilizantes com garantia, baseando-se no teor total e nos teores solúveis pelos diferentes extratores, e acumulado pelas plantas de arroz.

\begin{tabular}{|c|c|c|c|c|c|c|c|c|}
\hline \multirow{3}{*}{$\mathbf{N}^{\mathbf{9}}$} & \multirow{3}{*}{ Identificação } & \multicolumn{6}{|c|}{ Fornecido pelos fertilizantes } & \multirow{2}{*}{$\begin{array}{c}\text { Acumulado } \\
\text { pelas } \\
\text { plantas }\end{array}$} \\
\hline & & $\begin{array}{l}\text { Teor } \\
\text { total }\end{array}$ & água & $\begin{array}{l}\text { A.C. } \\
2 \%\end{array}$ & $\begin{array}{c}\text { C.N.A } \\
1+9\end{array}$ & DTPA & EDTA & \\
\hline & & \multicolumn{7}{|c|}{ - } \\
\hline 01 & FTE BR-12 & 68,2 & 9,20 & 33,5 & 14,7 & 6,70 & 3,70 & 9,50 \\
\hline 02 & FTE Sementes & 37,9 & 0,10 & 7,30 & 5,90 & 0,50 & 0,00 & 3,40 \\
\hline 03 & FTE JCO $2 \mathrm{M}$ & 87,0 & 0,00 & 26,9 & 2,90 & 3,10 & 0,00 & 12,8 \\
\hline 04 & FTE Centro Oeste & 63,8 & 9,90 & 32,4 & 2,40 & 13,9 & 1,70 & 3,50 \\
\hline 05 & Nutricitro 224 & 48,2 & 0,10 & 20,8 & 2,50 & 4,30 & 0,10 & 4,70 \\
\hline 08 & FTE Cerrrado S & 55,1 & 0,00 & 15,6 & 2,50 & 2,70 & 0,00 & 9,80 \\
\hline 11 & FTE BR - 8 & 103,6 & 0,00 & 15,1 & 1,00 & 2,20 & 0,00 & 2,50 \\
\hline 12 & Zincoman & 118,3 & 23,6 & 41,8 & 22,7 & 23,7 & 4,20 & 22,0 \\
\hline 14 & Mib - 3 & 20,5 & 14,2 & 18,8 & 2,80 & 6,40 & 1,40 & 6,30 \\
\hline 15 & Mib - 3 & 21,2 & 10,0 & 8,50 & 5,00 & 4,50 & 0,80 & 4,40 \\
\hline 17 & Mib - 28 & 80,2 & 32,0 & 39,8 & 11,7 & 19,6 & 6,90 & 19,2 \\
\hline 18 & Agrimax-12 & 19,9 & 0,90 & 5,40 & 0,30 & 0,80 & 0,20 & 1,50 \\
\hline 21 & Agrimax CO 150 & 68,7 & 05,2 & 25,2 & 4,40 & 4,80 & 1,00 & 12,3 \\
\hline 22 & HGB 12 & 81,8 & 0,00 & 45,8 & 2,50 & 7,20 & 0,40 & 16,7 \\
\hline 27 & Nitrex MS - 2 & 92,0 & 77,9 & 61,7 & 64,2 & 82,7 & 22,2 & 20,0 \\
\hline 29 & Copas -9 (citrus) & 107,0 & 95,7 & 108,0 & 106,0 & 108,0 & 16,9 & 67,4 \\
\hline
\end{tabular}


Tabela 21 - Quantidade de zinco fornecido pelos fertilizantes com garantia, baseando-se no teor total e nos teores solúveis pelos diferentes extratores, e acumulado pelas plantas de arroz.

\begin{tabular}{|c|c|c|c|c|c|c|c|c|}
\hline \multirow{3}{*}{$\mathbf{N}^{\mathbf{g}}$} & \multirow{3}{*}{ Identificação } & \multicolumn{6}{|c|}{ Fornecido pelos fertilizantes } & \multirow{2}{*}{$\begin{array}{c}\text { Acumulado } \\
\text { pelas } \\
\text { plantas }\end{array}$} \\
\hline & & $\begin{array}{l}\text { Teor } \\
\text { total }\end{array}$ & água & $\begin{array}{c}\text { A.C. } \\
2 \% \\
\end{array}$ & $\begin{array}{c}\text { C.N.A } \\
1+9 \\
\end{array}$ & DTPA & EDTA & \\
\hline & & \multicolumn{7}{|c|}{ - } \\
\hline 01 & FTE BR-12 & 205,3 & 11,8 & 65,1 & 34,3 & 52,5 & 25,0 & 18,7 \\
\hline 02 & FTE Sementes & 207,7 & 1,40 & 107,3 & 118,9 & 95,0 & 35,0 & 30,1 \\
\hline 03 & FTE JCO $2 \mathrm{M}$ & 41,4 & 0,00 & 27,8 & 4,80 & 7,50 & 2,00 & 20,9 \\
\hline 04 & FTE Centro Oeste & 179,3 & 7,10 & 56,3 & 25,5 & 53,5 & 38,0 & 28,2 \\
\hline 05 & Nutricitro 224 & 224,8 & 0,00 & 110,6 & 37,4 & 56,0 & 14,5 & 93,0 \\
\hline 07 & Hidrozinc Frit 20 & 201,3 & 79,8 & 115,1 & 52,0 & 89,5 & 52,0 & 119,0 \\
\hline 08 & FTE Cerrrado $S$ & 112,0 & 0,00 & 81,6 & 11,1 & 17,0 & 6,50 & 76,2 \\
\hline 09 & Zincogran 20 & 200,5 & 24,6 & 138,1 & 93,4 & 35,0 & 35,5 & 97,0 \\
\hline 10 & FTE BR - 18 & 179,2 & 7,80 & 68,9 & 66,7 & 90,0 & 55,0 & 85,0 \\
\hline 11 & FTE BR - 8 & 88,1 & 0,00 & 36,6 & 5,10 & 13,0 & 3,00 & 14,8 \\
\hline 12 & Zincoman & 82,6 & 24,5 & 54,8 & 42,2 & 58,5 & 33,5 & 61,3 \\
\hline 13 & Mib - 4 & 172,7 & 68,3 & 76,0 & 32,3 & 99,5 & 61,0 & 67,0 \\
\hline 14 & Mib- 3 & 77,8 & 37,8 & 54,0 & 54,8 & 69,5 & 40,5 & 12,0 \\
\hline 15 & Mib- 3 & 88,1 & 0,00 & 44,7 & 29,5 & 58,0 & 15,5 & 51,4 \\
\hline 16 & $\mathrm{Mib}-16 \mathrm{~A}$ & 304,0 & 63,7 & 93,2 & 66,4 & 39,0 & 41,0 & 99,0 \\
\hline 17 & Mib - 28 & 145,6 & 58,0 & 98,2 & 29,8 & 107,0 & 29,0 & 89,4 \\
\hline 18 & Agrimax-12 & 86,8 & 2,50 & 53,3 & 11,9 & 47,0 & 49,5 & 12,0 \\
\hline 19 & Gran-o-zinc 20 & 181,1 & 7,10 & 129,8 & 64,9 & 78,5 & 24,0 & 48,4 \\
\hline 21 & Agrimax CO 150 & 162,4 & 10,1 & 94,2 & 104,8 & 76,5 & 30,5 & 33,9 \\
\hline 22 & HGB 12 & 125,7 & 0,00 & 74,7 & 14,9 & 45,5 & 8,00 & 91,8 \\
\hline 23 & Plantzinco F IV & 542,5 & 0,10 & 339,0 & 174,4 & 73,0 & 19,0 & 103,0 \\
\hline 24 & Plantzinco F II & 200,8 & 11,4 & 100,0 & 90,4 & 72,5 & 30,5 & 102,8 \\
\hline 27 & Nitrex MS - 2 & 179,3 & 177,3 & 177,0 & 176,0 & 176,0 & 40,0 & 64,6 \\
\hline 28 & Copas - 8 (cafe) & 78,3 & 78,3 & 62,0 & 75,0 & 74,0 & 44,0 & 80,7 \\
\hline 29 & Copas - 9 (citrus) & 188,0 & 188,0 & 187,0 & 184,0 & 183,0 & 74,0 & 122,8 \\
\hline 30 & Nutri Oxi-Zn "C" & 291,2 & 219,2 & 223,0 & 217,0 & 206,0 & 49,0 & 78,6 \\
\hline
\end{tabular}


Tabela 22 - Coeficientes de correlação (r) encontrados entre a quantidade de cada micronutriente acumulado pelas plantas de arroz, após realização do teste de Neubauer e Schneider, e as quantidades fornecidas pelos fertilizantes, baseando-se no teor total e nos teores solúveis nos diferentes extratores.

\begin{tabular}{|c|c|c|c|c|c|}
\hline Extração & B & $\mathrm{Cu}$ & $\mathrm{Fe}$ & $\mathrm{Mn}$ & $\mathrm{Zn}$ \\
\hline Teor total & $0,88^{* *}$ & $0,56^{*}$ & $0,31^{\mathrm{ns}}$ & $0,57^{*}$ & $0,44^{*}$ \\
\hline Água & $0,56 * *$ & $0,32^{\mathrm{ns}}$ & $0,20^{\mathrm{ns}}$ & $0,83 * *$ & $0,41 *$ \\
\hline A.C. $2 \%$ & $0,75 * *$ & $0,64 * *$ & $0,63^{\text {ns }}$ & $0,93 * *$ & $0,51 * *$ \\
\hline C.N.A. $(1+9)$ & $0,80 * *$ & $0,73 * *$ & $0,46^{\mathrm{ns}}$ & $0,90 * *$ & $0,40^{*}$ \\
\hline DTPA & $0,84^{* *}$ & $0,39^{\text {ns }}$ & $0,16^{\mathrm{ns}}$ & $0,85 * *$ & $0,35^{\mathrm{ns}}$ \\
\hline EDTA & $0,61 * *$ & $0,49^{\mathrm{ns}}$ & $0,05^{\mathrm{ns}}$ & $0,69 * *$ & $0,26^{\mathrm{ns}}$ \\
\hline
\end{tabular}

Para o elemento boro observa-se que a correlação foi altamente significativa ao nivel de $1 \%$ para todos os extratores utilizados. Isto demonstra ainda mais que todos extratores solubilizaram coerentemente o boro solúvel de todas amostras, isto é, estão extraindo somente formas químicas semelhantes presentes nos diferentes fertilizantes. Isto provavelmente está indicando que foram usadas, na fabricação desses produtos, fontes com boro passível de ser liberado às plantas. E o maior valor de correlação apresentado entre a quantidade acumulada e a fornecida baseando-se no teor total, apesar de não ocorrer o esgotamento total do boro fornecido (Tabela 17), é um grande indicativo de que a garantia de boro nos fertilizantes por esse parâmetro, como contemplado pela legislação, é válida.

As maiores e mais significativas correlações entre a quantidade acumulada de cobre e as fornecidas baseando-se nos extratores, foi quando se utilizou os extratores $\mathrm{AC}$ e CNA; para os agentes quelantes DTPA e EDTA, assim como para a água, as correlações foram não significativas, comprovando a pouca efetividade desses extratores na avaliação da disponibilidade do cobre. Associando-se as pequenas quantidades de cobre solubilizadas pelos extratores (Figura 11), com a pequena recuperação do elemento pelas plantas, em relação ao teor total (Tabela 18), conclui-se 
que a garantia de cobre pelo teor total não foi um bom parâmetro: os extratores $\mathrm{AC}$ e CNA se mostraram mais efetivos.

As baixíssimas extrações de ferro pelos extratores, como visto na Figura 6, associada a recuperação do elemento pelas plantas de arroz (Tabela 19), provavelmente acabaram refletindo na não significância de todas as correlações apresentadas entre as quantidades acumuladas e as fornecidas. Nenhum extrator se definiu na solubilização do ferro realmente disponível às plantas. Uma conclusão geral foi de que o teor total de ferro é um parâmetro inadequado para definir disponibilidade do elemento.

Para o manganês observa-se, na Tabela 22, que o teor total foi o que apresentou a menor correlação com o acumulado pelas plantas; novamente esse parâmetro se mostrou inadequado para caracterizar a disponibilidade para as plantas. Para os outros extratores as correlações foram significativas, indicando que extraíram coerentemente as mesmas formas químicas presentes. Apesar de não haver ocorrido o esgotamento total de todo manganês fornecido (Tabela 20), o AC é o extrator que parece estar indicando melhor a solubilização do manganês para as plantas, seguido pelo CNA e DTPA. O extrator EDTA já havia mostrado baixa solubilização de todas formas solúveis (Figura $8)$.

$\mathrm{O}$ extrator que melhor caracterizou a disponibilidade de zinco foi o $\mathrm{AC}$, com correlação significativa ao nível de $5 \%$. Porém, os valores dessas correlações foram bem baixos, quando comparado com as correlações encontradas para os outros micronutrientes estudados, Isto pode ser um reflexo das altas doses de zinco fornecidas pelos fertilizantes. Os agentes quelantes novamente não se mostraram promissores.

$O$ teste de Neubauer e Schneider discutido neste trabalho foi utilizado por ser um teste de rápida realização. Observou-se coerências entre o boro absorvido pelas plantas e o que foi extraido dos fertilizantes pelos extratores. O mesmo ocorreu para os micronutrientes metálicos. Porém, esses resultados não são definitivos. Uma concordância geral para o cobre, ferro, manganês e zinco, foi que o teor total realmente não está caracterizando a disponibilidade desses micronutrientes nos fertilizantes. Um estudo mais aprofundado com esses extratores mais promissores, e também com outros, será de grande importância. 


\section{CONCLUSÕES}

Os fertilizantes tipo "fritas" apresentaram baixa solubilidade dos micronutrientes catiônicos (cobre, ferro, manganês e zinco) em todos os extratores utilizados.

De acordo com o teste de Neubauer \& Schneider, o ácido cítrico a $2 \%$ se mostrou promissor na caracterização da disponibilidade de cobre, manganês e zinco para as plantas. Para o ferro, não houve uma definição entre os extratores estudados.

$\mathrm{O}$ boro teve boa solubilidade, tanto nos fertilizantes solúveis, como nos insolúveis em água. A garantia pelo teor total mostrou-se um bom indicativo da disponibilidade do elemento.

Para o molibdênio, produtos mais solúveis foram utilizados nos fertilizantes com baixo teor do elemento, enquanto que os com teor mais elevado tenderam a uma menor solubilidade em água, mas solúveis nos extratores, indicando disponibilidade.

A garantia dos micronutrientes catiônicos pelo teor total, conforme exige a legislação, não indicou a real disponibilidade dos micronutrientes nos fertilizantes. Mostra-se necessária a definição de extratores para esse fim. 


\section{REFERÊNCIAS BIBLIOGRÁFICAS}

ALCARDE, J.C. Qualidade de fertilizantes e corretivos. In: REUNIÃo BRASILEIRA DE FERTILIDADE DO SOLO E NUTRIÇÃO DE PLANTAS, 20., Piracicaba, 1992. Anais. Campinas: Fundação Cargill, 1992. p. 275-298.

ALCARDE, J.C.; PONCHIO, C.O. A ação solubilizante das soluções de citrato de amônio e de ácido cítrico sobre fertilizantes fosfatados. Revista Brasileira de Ciência do Solo, v.3, p. 173-178, jan/abr., 1979.

ALCARDE, J.C.; RODELLA, A.A.. Caracterização de fertilizantes simples contendo zinco. Scientia Agrícola, v. 50, n.1, p. 121-126, fev/maio, 1993.

AMARAL, R.D. Avaliação de um resíduo da indústria de zinco como corretivo da acidez e fertilizante do solo e fonte de metais pesados para as plantas. Viçosa, 1994. 70 p. Dissertação (Mestrado) - Universidade Federal de Viçosa.

AMARAL SOBRINHO, N.M.B. Interação dos metais pesados de resíduos siderúrgicos com um solo podzólico vermelho amarelo. Viçosa, 1993. 163 p. Tese (Doutorado) - Universidade Federal de Viçosa.

AMARAL SOBRINHO, N.B.; COSTA, L.; OLIVEIRA, C.; VELLOSO, A.C.X. Metais Pesados em alguns fertililizantes e corretivos. Revista Brasileira de Ciência do Solo, v.16, n.2, p. 271-276, maio/ago, 1992.

ARNON, D.I.; STOUT, P.R. The essenciality of certain elements in minute quantity for plants with special reference to copper. Plant Physiology, v.14, p. 371-375, abril, 1939. 
ASSOCIATION OF OFFICIAL ANALYTICAL CHEMISTS. Official methods of analysis. 14. ed. Arlington: S. Willians, 1984. $1141 \mathrm{p}$.

BRASIL, Ministério da Agricultura. Inspeção e fiscalização da produção e do comércio de fertilizantes, corretivos, inoculantes, estimulantes e biofertilizantes destinados à agricultura - Legislação e Fiscalização. Brasilia: Secretaria Nacional de Defesa Agropecuária, Divisão de Corretivos e Fertilizantes, 1982. 88 p.

BRASIL, Ministério da Agricultura. Análises de corretivos, fertilizantes e inoculantes - Métodos oficiais. Brasilia: Laboratório Nacional de Referência Vegetal (LANARV)/ Secretaria Nacional de Defesa Agropecuária, 1983. 104 p.

CATANI, R.A.; BERGAMIN FILHO, H. Sobre uma modificação no método de Neubauer. Anais da Escola Superior de Agricultura Luíz de Queiroz, n. 18, p. 287-299, 1961.

CATANI, R.A.; PAIVA NETTO, J.E. O método de Neubauer aplicado ao estudo do potássio nos solos do Estado de São Paulo. Bragantia, n. 10, p. 27-32, 1950

GIORDANO, P.M. Efficiency of zinc fertilization for flooded rice. Plant and Soil, v. 48, p. 673-684, nov., 1977.

HOAGLAND, D.R.; ARNON, D.I. The water culture methods of growing plants without soil. Berkeley : University of California. 1950.

LINDSAY, W.L.; NORVELL, W.A. Development of a DTPA soil test for zinc, iron, manganese, and copper. Soil Science Society of American Journal, v.42, p. 421428,1978 . 
LOPES, A.S. Uso eficiente de fertilizantes com micronutrientes. In: SIMPÓSIO SOBRE FERTILIZANTES NA AGRICULTURA BRASILEIRA, 1., Brasilia, 1984. Anais. Brasilia: EMBRAPA, 1984. p. 347-382.

LOPES, A.S. Micronutrientes: filosofias de aplicação, fontes, eficiência agronômica e preparo de fertilizantes In: FERREIRA, M.E.; CRUZ, M.C.P. Micronutrientes na Agricultura. Piracicaba: Potafós, 1991. p. 357-390.

MALAVOLTA, E. Elementos de nutrição mineral de plantas. São Paulo: Agronômica Ceres, 1980, $210 \mathrm{p}$.

MALAVOLTA, E. Manual de química agrícola: adubos e adubação. 3.ed. São Paulo: Agronômica Ceres, 1981. 596 p.

MALAVOLTA, E. Fertilizantes e seu impacto ambiental: micronutrientes e metais pesados, mitos, mistificação e fatos. São Paulo: Produquímica, 1994. 153 p.

MALAVOLTA, E.; VITTI, G.C.; OLIVEIRA, S.A - Avaliação do estado nutricional das plantas: princípios e aplicações. Piracicaba: Potafós, 1989. $201 \mathrm{p}$.

MATTIAZZO-PREZOTTO, M.E. Comportamento de cobre, cádmio, crômio, níquel e zinco adicionados a solos de clima tropical em diferentes valores de $\mathrm{pH}$. Piracicaba, 1994. 197 p. Tese (Livre-Docência) - Escola Superior de Agricultura "Luiz de Queiróz", Universidade de São Paulo.

MELLO, F.A.F. Avaliação do teor de cálcio disponível do solo utilizando o método de Neubauer \& Schneider. Revista de Agricultura, v.48, p. 167-174, 1973.

MORTVEDT, J.J. Micronutrient fertilizers and fertilization practices. Fertilizer Research, v.7, p. 221-235, 1985. 
MORTVEDT, J.J.; CUNNINGHAM, H.G. Production, marketing, and use of other secondary and micronutrient fertilizers. In: OLSON, R.A.; ARMY, T.J.; HANWAY, J.J.; KILMER, V.J. (ed.) Fertilizer technology and use, 2.ed. Madison: Soil Science Society of America, 1971. p.413-454.

MURAOKA, T.; NEPTUNE, A.M.L.; NASCIMENTO FILHO, V.F. Avaliação da disponibilidade de zinco e de manganês do solo para o feijoeiro. I. Zinco. Revista Brasileira de Ciência do Solo, v.7, n.2, p. 167-175, maio/ago., 1983.

MURAOKA, T.; NEPTUNE, A.M.L.; NASCIMENTO FILHO, V.F. Avaliação da disponibilidade de zinco e de manganês do solo para o feijoeiro. II.Manganês. Revista Brasileira de Ciência do Solo, v.7, n.2, p. 177-182, maio/ago., 1983.

NIKITIN, A.A. Production and use of trace salts in fertilizers. In: SAUCHELLI, V. (ed.) The chemistry and technology of fertilizers. New York: Reinhold Publ. Corp. 1960. p. 435-445.

PROCHNOW, L.I. Disponibilidade do fósforo da fração solúvel em citrato neutro de amônio e insolúvel em água de fosfatos acidulados. Piracicaba, 1996. 157 p. Tese (Doutorado) - Escola Superior de Agricultura "Luiz de Queiróz", Universidade de São Paulo.

RAIJ, B. van. Fertilidade do solo e adubação. Piracicaba: Potafós, 1991a. 343p.

RAIJ, B. van. Geoquímica de micronutrientes. In: FERREIRA, M.E.; CRUZ, M.C.P. Micronutrientes na Agricultura. Piracicaba: Potafós, 1991b. p. 99-111.

RINGBOM, A. Complexation in analytical chemistry. New York: Interscience Publishers, 1963. 395p. 
SANTOS, O.S.; CERETTA, C.A.; PITOL, C.; CAMARGO, R.P. Efeitos de dosagens de molibdênio, cobalto, zinco e boro aplicados nas sementes, sobre características agronômicas da soja - 3. ano. In: REUNIÃO DE PESQUISA DE SOJA DA REGIÃO SUL, 10., Porto Alegre, 1982. Contribuição do Centro de Ciências Rurais. Santa Maria: Universidade Federal, 1982. p. 24-27.

VOLKWEISS, S.J. Formas e métodos de aplicação. In: FERREIRA, M.E.; CRUZ, M.C.P. Micronutrientes na Agricultura. Piracicaba: Potafós, 1991. p 391-412. 